\title{
WestVirginiaUniversity
}

THE RESEARCH REPOSITORY @ WVU

Graduate Theses, Dissertations, and Problem Reports

2012

\section{Coyote diets in West Virginia}

\author{
Geriann Albers \\ West Virginia University
}

Follow this and additional works at: https://researchrepository.wvu.edu/etd

\section{Recommended Citation}

Albers, Geriann, "Coyote diets in West Virginia" (2012). Graduate Theses, Dissertations, and Problem Reports. 3529.

https://researchrepository.wvu.edu/etd/3529

This Thesis is protected by copyright and/or related rights. It has been brought to you by the The Research Repository @ WVU with permission from the rights-holder(s). You are free to use this Thesis in any way that is permitted by the copyright and related rights legislation that applies to your use. For other uses you must obtain permission from the rights-holder(s) directly, unless additional rights are indicated by a Creative Commons license in the record and/ or on the work itself. This Thesis has been accepted for inclusion in WVU Graduate Theses, Dissertations, and Problem Reports collection by an authorized administrator of The Research Repository @ WVU. For more information, please contact researchrepository@mail.wvu.edu. 


\title{
Geriann Albers
}

\author{
Thesis submitted to the \\ Davis College of Agriculture, Natural Resources and Design \\ at West Virginia University \\ in partial fulfillment of the requirements \\ for the degree of
}

\author{
Master of Science \\ in \\ Wildlife and Fisheries Management \\ John W. Edwards, Ph.D., Major Professor \\ James T. Anderson, Ph.D. \\ Richard E. Rogers, M.S.
}

Division of Forestry and Natural Resources

Morgantown, West Virginia

2012

Keywords: Canis latrans, coyote, diet, livestock, Odocoileus virginianus, West Virginia, white-tailed deer

Copyright 2012 Geriann Albers 


\section{ABSTRACT \\ Coyote Diets in West Virginia}

\section{Geriann Albers}

Coyotes were not present in the mid-Atlantic region until the 1950s and little is known regarding their ecology in this region. My objective was to examine the diets of coyotes in West Virginia and to compare diets among regions and seasons as well as between age and sex. I also analyzed the occurrence of livestock in coyote diets and used logistic regression and Akaike's Information Criterion to analyze potential factors influencing livestock consumption by coyotes. In cooperation with the West Virginia Division of Natural Resources, USDA AHPIS Wildlife Services, and hunters and trappers, I collected coyote scat and stomachs throughout West Virginia during November 2009-June 2011. I found white-tailed deer (Odocoileus virginianus) to be the most frequently occurring item in samples at $59.5 \%$, followed by plant material (39.7\%), small mammals (19.3\%), fruits and seeds (16.1\%), and squirrels (Sciurus spp., Tamiasciurus hudsonicus) and chipmunks (Tamias striatus; $11.4 \%$ ). Deer also had the highest mean percent volume (44.9\%), followed by small mammals $(11.8 \%)$, squirrels and chipmunks $(8.2 \%)$, fruits and seeds $(7.1 \%)$, and plant material (7.1\%). I found occurrence of anthropogenic items in diets was lower than most natural items. I found percent occurrence of common items to vary among seasons and regions. For instance, deer occurred most frequently during JanuaryApril while fruits and seeds occurred most frequently during September-December. Regionally, the Southern Region had the lowest occurrence of deer in scat and stomach samples and the highest occurrence of fruit and seeds. Low occurrence of deer in the Southern Region coincided with lower deer density in that region. I found juvenile coyotes had deer in their stomachs more frequently and fruit and seeds less frequently than adults $(P=0.009)$. Livestock occurred more commonly in male coyote stomachs than females $(P=0.039)$. I found livestock in $6.3 \%$ of coyote diets, including both scat and stomach samples. In stomach samples, which were obtained primarily from USDA APHIS Wildlife Services Specialists and fur trappers, livestock occurred in $17.4 \%$ of samples, compared to $1.9 \%$ in scat samples. I noted livestock to occur more frequently in coyote diets during January-April and found the Eastern Panhandle had higher occurrence of livestock and the Southern Region to have lower occurrence of livestock in coyote diets than other regions. Greater livestock occurrence in coyote diets during the JanuaryApril coincided with peak lambing season. Regional differences in livestock occurrence were possibly due to a combination of differences in livestock production and unequal sampling. 


\section{ACKNOWLEDGMENTS}

I thank my committee members, Dr. John Edwards, Dr. James Anderson, Lauren Mastro, Rich Rogers, and Dr. Chris Ryan and my funding sources, the West Virginia Division of Natural Resources, USDA APHIS Wildlife Services, West Virginia Division of Natural Resources, and The Berryman Institute. A big thank you to all the West Virginia Division of Natural Resources personnel, USDA APHIS Wildlife Services staff, hunters, trappers, and the West Virginia Trappers Association for all their help in sample collection. Thank you to my parents Jerry and Marian Albers and my brother Jim Albers for all their love and support. Thank you to all the graduate students who gave me guidance and assistance throughout my project, especially Alison Anderson for logistics and Andrew Tri and John Burkhardt who were invaluable for statistical advice. Thanks to Mike Jones, Andrew Tri, and Jacob Berl for critical review. Thanks to all my volunteers, my interns Logan Riggleman, Jake Benhoff, Robert Fouts, Evan Neukom, and Braeden Harpool, and my technician Mark Beerse. Finally, a special thank you to the best technician that ever was, Logan Moon. It was the best day of my raccoon life when you came to work for me and I'd still be processing samples if it weren't for you. 


\section{TABLE OF CONTENTS}

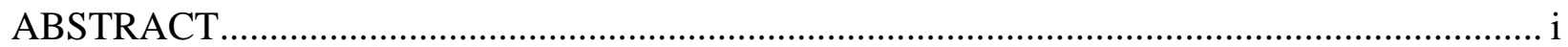

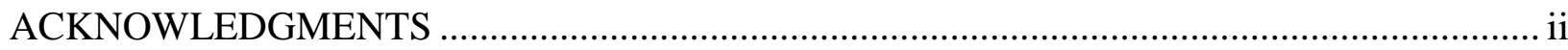

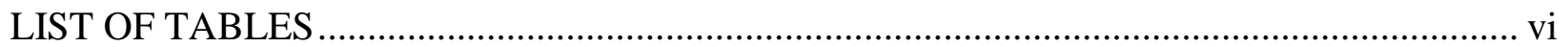

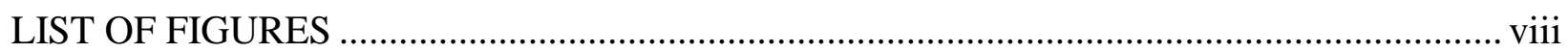

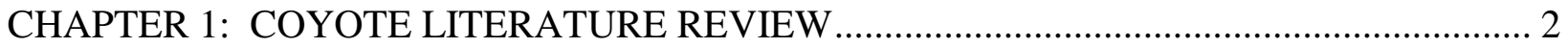

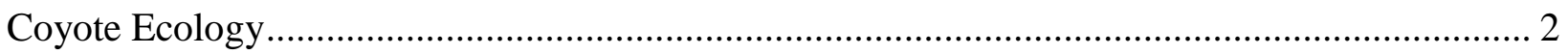

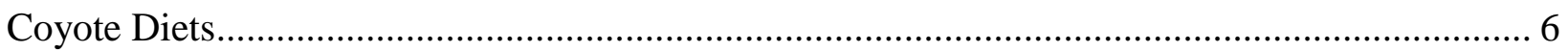

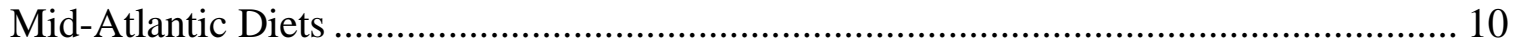

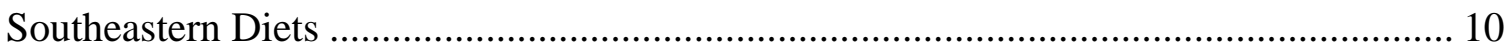

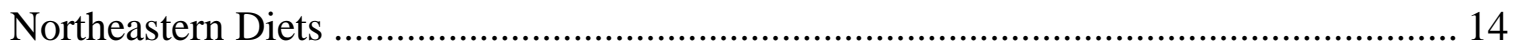

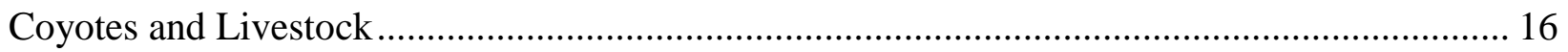

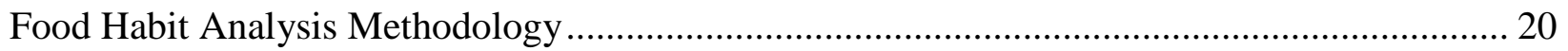

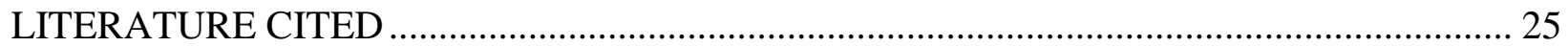

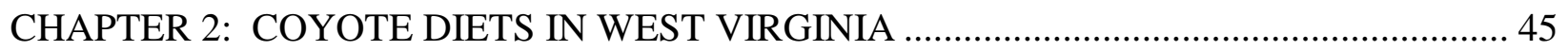

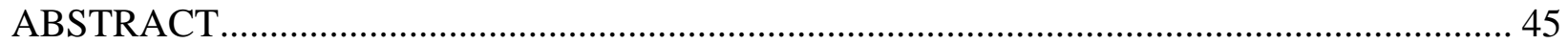

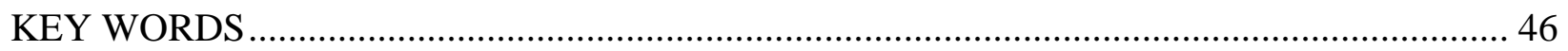

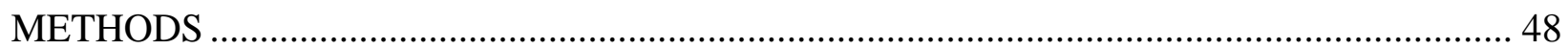

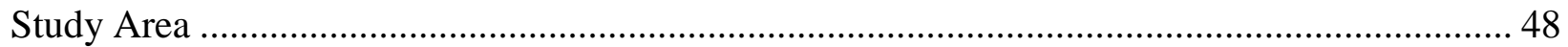

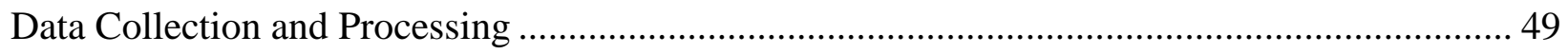


Stomachs

Scat. 50

Spotlight Distance Surveys . 51

Statistical Analysis 52

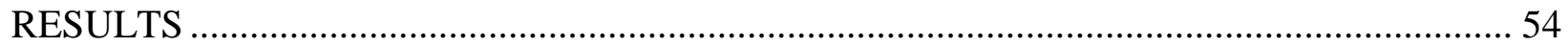

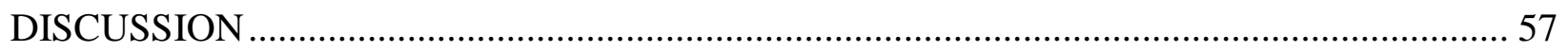

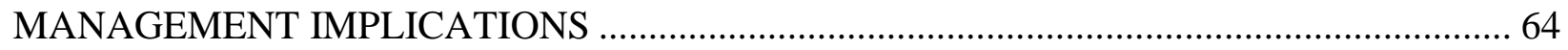

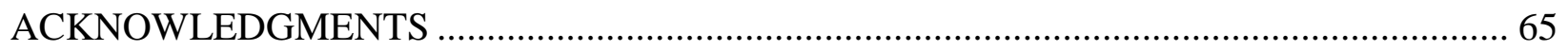

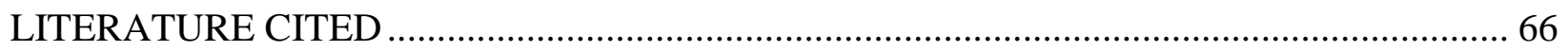

CHAPTER 3: LIVESTOCK OCCURRENCE IN DIETS OF COYOTES IN WEST VIRGINIA

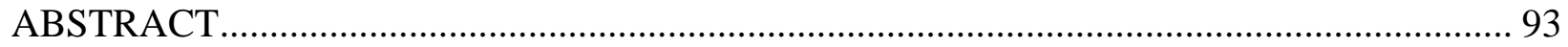

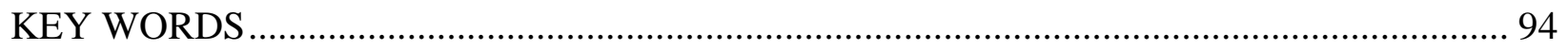

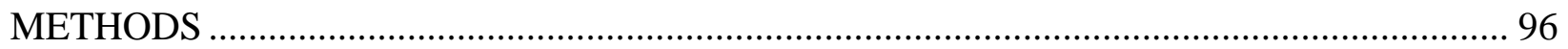

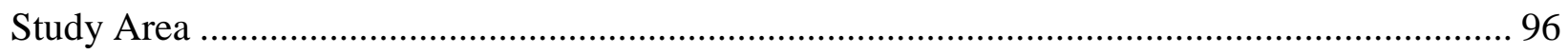

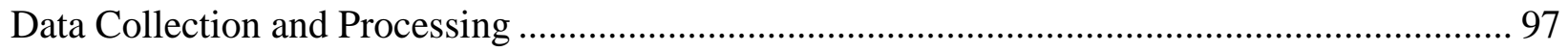

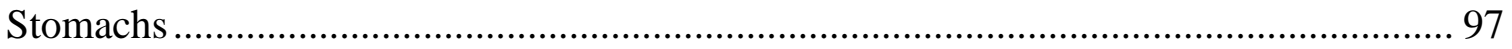

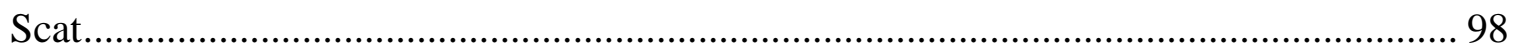

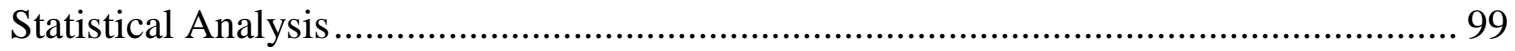

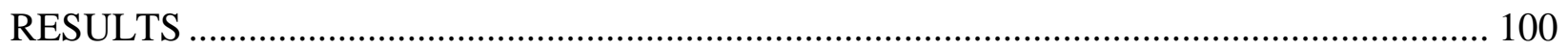

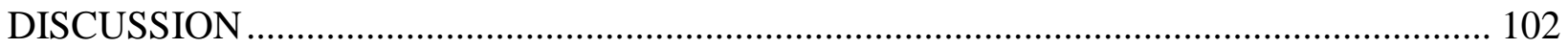




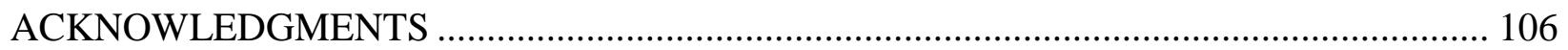

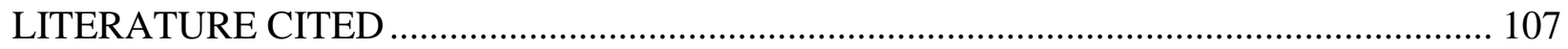

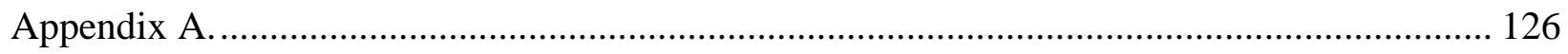

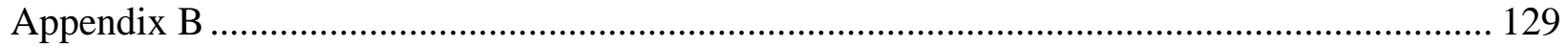

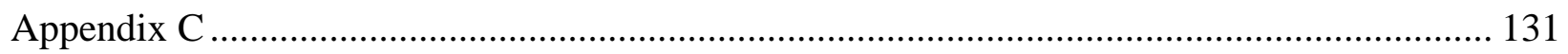

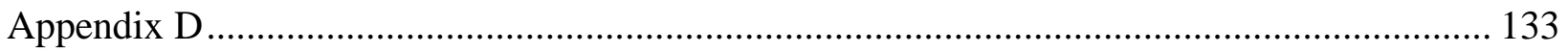

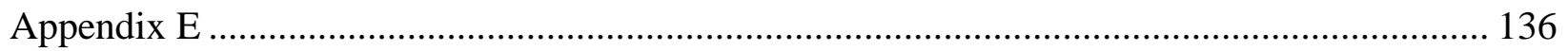

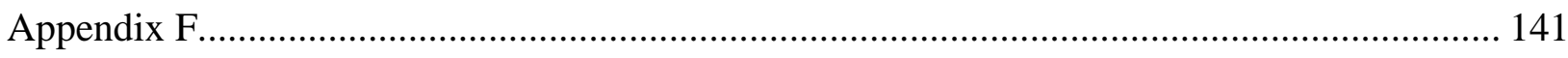

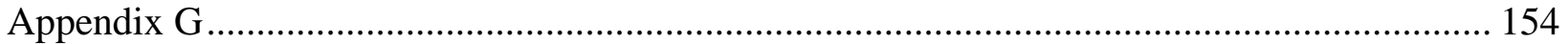

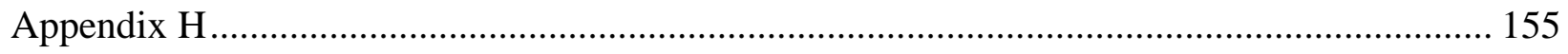

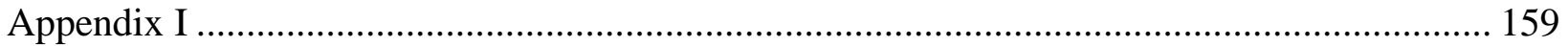

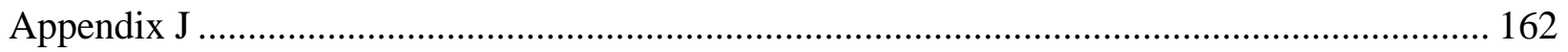




\section{LIST OF TABLES}

Table 1. Occurrence of common items in coyote stomach samples among seasons in West Virginia, November 2009-June 2011. Sample size is in parentheses.................................... 78

Table 2. Percent occurrence common items in coyote stomach samples in West Virginia during November 2009-June 2011. Sample size is in parentheses. 79

Table 3. Percent occurrence comparisons between years of common items in coyote stomach samples in West Virginia, November 2009-June 2011. Sample size is in parentheses. 80

Table 4. Percent occurrence of common items in male and female coyote stomach samples in West Virginia, November 2009-June 2011. Sample size is in parentheses. 81

Table 5. Percent occurrence of common items in coyote scat and stomach samples between adults ( $>1$ year) and juveniles (<1 year) in West Virginia, November 2009-June 2011. Sample size is in parentheses. 82

Table 6. Percent occurrence of commonly items in coyote diets among regions in West Virginia, November 2009-June 2011. Sample size is in parentheses. 83

Table 7. Ranking matrix for proportional coyote diets in West Virginia, November 2009-June 2011. Each mean element was replaces by its sign; a triple sign indicates significant deviation from random at $\mathrm{P}<0.05$. Items on the $\mathrm{y}$ (or vertical) axis are the primary comparison. For example, livestock is significantly less selected than deer if you are moving down the column, or deer is significantly more selected than livestock if you are moving across the row. 84

Table 8. White-tailed deer distance survey results from the 3 counties of focus in West Virginia, November 2009-June 2011 85 
Table 9. Percent occurrence of livestock in coyote scat and stomach samples collected in West Virginia, November 2009-June 2011. Sample size is in parentheses. 113

Table 10. Percent occurrence of livestock in coyote scat and stomach samples for season in West Virginia, November 2009-June 2011. Columns may not sum as goat and horse was excluded due to low occurrence in samples. Sample size is in parentheses.

Table 11. Percent occurrence of livestock in coyote scat and stomach samples for region in West Virginia, November 2009-June 2011. Columns may not sum as goat and horse was excluded due to low occurrence in samples. Sample size is in parentheses. 115

Table 12. Percent occurrence of livestock in male and female coyote scat and stomach samples in West Virginia, November 2009-June 2011. Columns may not sum as goat and horse was excluded due to low occurrence in samples. Sample size is in parentheses. 116

Table 13. Percent occurrence of livestock in coyote diets between age classes in West Virginia, November 2009-June 2011. Columns may not sum as goat and horse was excluded due to low occurrence in samples. Sample size is in parentheses.

Table 14. Candidate models and results of logistic regression of livestock occurrence in coyote diets in West Virginia, November 2009-June 2011. 118

Table 15. Inventory of cattle, calves, sheep and lambs among regions within West Virginia in 2007 as reported by the USDA National Agriculture Statistics Services QuickStats program. 


\section{LIST OF FIGURES}

Figure 1. The 6 ecological regions and the 3 focus regions and counties in West Virginia (Uhlig and Wilson 1952) where coyote scat and stomach samples were collected during November 2009-June 2011. 86

Figure 2. The distribution of coyote samples ( $\mathbf{\Delta}$ ) throughout West Virginia, November 2009June 2011. 86

Figure 3. Percent occurrence of common items in coyote scat and stomach samples among seasons in West Virginia, November 2009-June 2011. Percent occurrence is likelihood of an item being found in a sample, so total will not sum to 100 . 86

Figure 4. Percent occurrence of common items in coyote diets among regions in West Virginia, November 2009-June 2011. Percent occurrence is likelihood of an item being found in a

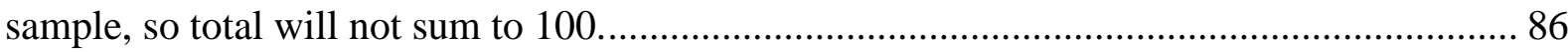

Figure 5. Percent occurrence of deer in coyote diets among months in West Virginia, November 2009-June 2011. December was excluded due to small sample size. 86

FIGURE LEGENDS 120

Figure 6. The 6 ecological regions and the 3 focus regions and counties in West Virginia (Uhlig and Wilson 1952) used for the coyote diet study.

Figure 7. The distribution of coyote scat and stomach samples throughout West Virginia, November 2009-June 2011

Figure 8. Percent occurrence of livestock in coyote samples among seasons in West Virginia, November 2009-June 2011. Percent occurrence is likelihood of an item being found in a sample, so total will not sum to 100 . 
Figure 9. Percent occurrence of livestock in coyote stomach and scat samples among regions in West Virginia, November 2009-June 2011. Percent occurrence is likelihood of an item being

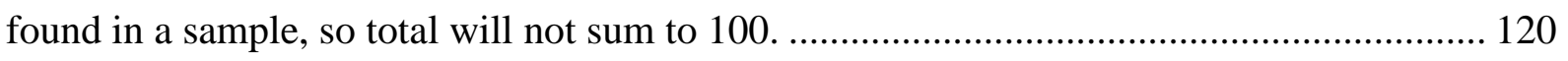




\section{LIST OF APPENDICES}

Appendix A. All items identified in diets and the aggregate categories we identified in coyote diets in West Virginia November 2009-June 2011.

Appendix B: Percent occurrence of items in coyote scat and stomach samples collected in West

Virginia, November 2009-June 2011.

Appendix C. Volume (\%) of diet items from coyotes in West Virginia, November 2009-June 2011

Appendix D: Summary of coyote diet literature in the Eastern United States.

Appendix E. Sample sizes broken down by region in the state of West Virginia, season of the year, and age class and sex of coyote (for stomach samples) for coyote diets in West Virginia during November 2009-June 2011. 136

Appendix F. Age data for all coyote collected as part of the West Virginia coyote diet study from November 2009-June 2011 based upon lower canine teeth sent to Matson's Laboratory (Milltown, MT). To reduce costs, some teeth were xrayed to look for root tip closure (indicating the animal is a juvenile) before being sent to Matson's, so this list does not represent every coyote carcass collected.

Appendix G. Reproduction information for female coyotes with fetuses present in West

Virginia, January-May 2010.

Appendix H. Number of coyote scat collected by county, year, and month in West Virginia, November 2009-June 2011 155

Appendix I. Maps of scat routes in Lewis, Pocahontas, and Raleigh Counties, West Virginia, where coyote scat collection occurred January 2010-May 2011 
Appendix J. Maps of deer distance survey routes in Lewis, Pocahontas, and Raleigh Counties, West Virginia where distance surveys were conducted as part of the Coyote Diet Study in

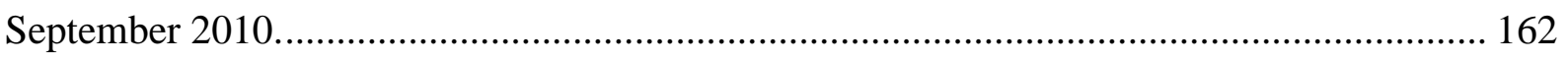


CHAPTER 1

COYOTE LITERATURE REVIEW 


\section{CHAPTER 1}

\section{COYOTE LITERATURE REVIEW}

\section{Coyote Ecology}

Coyotes (Canis latrans) are 1 of 8 species in the genus Canis, including the gray wolf (C. lupus), the red wolf (C. rufus), and the domestic dog (C. familiaris). Historically a western plains species, coyotes now occur from Alaska to Central America (Bekoff and Gese 2003). In recent decades, coyotes have greatly expanded their range to include almost all of the contiguous United States and parts of Canada and Central America (Moore and Parker 1992). While many carnivores in North America have suffered range declines over the past few decades, coyotes have actually expanded their range (Laliberte and Rippe 2004). Research suggests that coyotes took three routes in their colonization of the eastern United States, a northern route through Ontario, a central route through Ohio (Moore and Parker 1992, Kays et al. 2010), and a southeastern route through Mississippi (Moore and Parker 1992). Early records of coyotes in the mid-Atlantic date to Pennsylvania in the 1930s and 1940s (Hilton 1978, McGinnis 1979), though coyotes did not reach Delaware until the 1990s (Parker 1995). The mid-Atlantic is thought to be one of the last areas in the United States colonized by coyotes (Moore and Parker 1992). Anecdotal evidence based on skull morphology suggests coyotes expanded into West Virginia primarily from Ohio and Kentucky, with Pennsylvania being a secondary introduction point (Wykle 1999). Genetic research of coyotes in northern Virginia showed individuals to be most closely related to coyotes from Pennsylvania and New York, but had haplotypes from numerous areas throughout the United States (Bozarth et al. 2011). Coyotes were reported in Ohio as early as 1919 (Weeks et al. 1990). A survey of Ohio conservation officers conducted in 1979 reported 
coyotes in 46 of 88 counties (52\%; Weeks et al. 1990). Coyotes were first documented in the late 1930s and early 1940s in Pennsylvania (Hilton 1978, Hayden 2003), in northern Virginia near the eastern border with West Virginia in the mid-1960s (Carpenter 1971) and in Tucker County, West Virginia in 1950 (Taylor et al. 1976). More frequent sightings in Virginia (Carpenter 1971) and in West Virginia (Taylor et al. 1976) began in the 1970s and sightings were common in West Virginia by the 1990s (Wykle 1999).

Landscape changes such as agricultural expansion (Moore and Parker 1992) and possibly hybridization with wolves (Canis spp.; Kays et al. 2010) may have facilitated eastward expansion of coyotes. The human eradication of major predators such as wolves and mountain lions (Puma concolor) also may have allowed for the spread of coyotes into new areas, including the Appalachians (Moore and Parker 1992, Bekoff and Gese 2003). Human introductions of coyotes in the southeastern United States also are thought to have contributed to range expansion (Taylor et al. 1976, Gipson 1978). Taylor et al. (1976) recorded human introductions of coyotes in West Virginia (2 recorded introductions) and Hill et al. (1987) reported introductions of coyotes in Florida (5), Georgia (5), Alabama (3), Tennessee (3), Mississippi (2), North Carolina (1), and Virginia (1). Seven of these instances were for hunting with dogs, 3 were escapees, and 10 were for undetermined reasons (Hill et al. 1987). Such introductions are believed to have contributed and possibly expedited the expansion of the coyote throughout the Southeast (Hill et al. 1987).

Coyote size varies by geographic region. Generally males are larger than females with males averaging 10-16 kg, and females averaging 9-14 kg (Bekoff and Gese 2003). Eastern coyotes are larger than their western counterparts (Nowak 1978, 1979, Thurber and Peterson 1991, Kays et al. 2010). Recent genetic research suggests coyotes in the northeastern United 
States share haplotypes with wolves and may have crossed with them when colonizing the region (e.g., Kays et al. 2010, Bozarth et al. 2011). Female coyotes are seasonally monestrous and usually breed between January and March, giving birth approximately 63 days later (Bekoff and Gese 2003). Litter size varies based on prey availability, but averages 6 pups (Bekoff and Gese 2003). Coyotes can hybridize with both wolves and dogs, though hybridization with dogs generally leads to decreased fecundity (Bekoff and Gese 2003). Wykle (1999) reported coyotes in West Virginia exhibit some sexual dimorphism. Males were heavier $(n=33, \bar{x}=14.5 \mathrm{~kg})$ than females $(n=33, \bar{x}=11.8 \mathrm{~kg})$ and males had more pronounced sagittal crests (Wykle 1999). Coyotes will hunt in packs, which often consist of an alpha male and female, their pups, and occasionally offspring from the previous year that remain with the group (Bekoff and Gese 2003). Coyotes, like some other canids, may be social animals, though solitary animals do occur (Bekoff and Gese 2003). Coyotes usually hunt in packs for larger game such as ungulates, while small mammal hunting is primarily done individually (Gese et al. 1988, Gese 2004). This is thought to occur because cooperation is not needed to obtain small mammals and food is not shared (Gese et al. 1988, Gese 2004). Patterson and Messier (2000) found an increase in group size did not increase hunting success when hunting larger prey. Fluctuations in prey items have led to documented changes in coyote abundance (Gese 2004) and coyote dispersal (Patterson and Messier 2001). Social cohesion seems to occur most during winter, possibly related to feeding patterns or delayed juvenile dispersal (Gese et al. 1988).

Coyotes have been shown to prey upon large prey such as adult deer (Compton 1980, Gese and Grothe 1995, Lingle 2000, Muntz and Patterson 2004), bison (Bison bison) calves (Sheldon et al. 2009), elk (Cervus canadensis, Gese and Grothe 1995), and harp seals (Pagophilus groenlandicus, Way and Horton 2004) especially when hunting in packs (Gese and 
Grothe 1995, Muntz and Patterson 2004). Coyote predation on deer, both white-tailed (Odocoileus virginianus) and mule (O. hemionus), is a highly debated topic and one of interest to both hunters and managers. Numerous studies have attributed varying amounts of fawn mortality to coyotes (e.g., Whittaker and Lindzey 1999, Vreeland et al. 2004, Rohm et al. 2007, Saalfeld and Ditchkoff 2007, Piccolo et al. 2010). Coyotes also have been observed killing adult white-tailed and mule deer (Compton 1980, Lingle 2000, Muntz and Patterson 2004). Some studies suggest that coyotes can negatively affect deer populations, especially in the Southeast (Schrecengost et al. 2008, VanGlider 2008, Kilgo et al. 2010, Jackson 2011), but others do not concur (Turner et al. 2011). Studies also suggest that predation on deer may increase with an increase in snow depth when deer are more vulnerable (Lavigne 1992, Patterson et al. 1998, Patterson and Messier 2000). Deer mortality due to coyotes has been shown to be additive in some instances (Messier et al. 1986, Patterson et al. 2002, Patterson and Messier 2003), but compensatory in others (Bartmann et al. 1992, Bishop et al. 2009). The effects of coyote predation on deer population dynamics has been difficult to study and not well understood, especially in newly colonized areas like the mid-Atlantic region.

Consumption rates of prey items, energy use, and metabolism rates are areas of coyote ecology that are challenging to study (Pekins 1992). Limited work has been completed in this area, and most of what research does exist was completed on captive animals. Hilton (1978) documented captive coyotes consumed 3 beaver carcasses at a rate of $0.72 \mathrm{~kg}$ of meat/coyote/day. Hilton (1978) also documented coyote consumption of a deer in Maine by 2-3 wild coyotes to be 3.7-5.6 kg of meat/day/coyote. Litvaitis and Mautz (1980) fed white-tailed deer, snowshoe hare (Lepus americanus), and lab mice (mus musculus) to 4 captive coyotes. Litvaitis and Mautz found deer dry matter digestibility $(96.8 \%)$ to be higher than hare (81.5\%) or 
mice (93.2\%), and metabolizable energy values of deer (4.99 kcal/g dry matter) and mice (5.07 $\mathrm{kcal} / \mathrm{g}$ dry matter) to be higher than hare $(4.01 \mathrm{kcal} / \mathrm{g}$ dry matter). However, these coyotes were kept in a collection enclosure and were fed ground material with all bones, hair, and large amounts of fat removed (Litvaitis and Mautz 1980), which could limit interpretability to wild coyotes. Pekins (1992) provides a summary of the limited knowledge of bioenergetics of eastern coyotes.

\section{Coyote Diets}

Coyote diets usually vary seasonally (e.g., MacCracken and Hansen 1982, Gese et al. 1988, Grogan 1996, Quinn 1997, Patterson et al. 1998) and with successional changes in vegetation (Andelt et al. 1987). MacCracken and Uresh (1984), however, did not document seasonal changes in coyote diets. Coyote diets also vary by region and prey availability (Tremblay et al. 1998, Bekoff and Gese 2003). Coyotes have been found to select foraging areas based on prey density (Reichel 1991). Patterson et al. (1998) and Patterson and Messier (2000) suggested that prey switching in coyotes may be influenced by changes in prey diversity, abundance, and vulnerability. Sacks and Neale (2007) found coyote abundance to be positively associated with plant productivity, which suggests coyote numbers respond to overall prey base. Coyotes have the potential to impact endangered species such as sea turtles (Cheloniidae and Dermochelyidae; Lamont et al. 1998) and snowy plovers (Charadirus alexandrines; Pruner 2010). Habitat is an important factor influencing predation rates, especially on small mammals (Gese 2004). Fedriani et al. (2001) suggested coyotes may have higher densities in areas with anthropogenic food sources to supplement diets. Morey et al. (2007) further supported this hypothesis by documenting that coyotes in more developed areas had more diverse diets. 
Coyote predation on birds, especially game birds, has been documented in several regions of the country (e.g., Miller et al. 1998, Paisley et al. 1998, Hubbard et al. 1999, Henke 2002). Henke (2002) documented very low occurrence of northern bobwhite quail (Colinus virginianus) in coyote diets in southern Texas. Predation by coyotes on turkey (Meleagris gallopavo) poults was documented in Iowa, but in lower numbers (14.3\% of predation) than other predators such as foxes (28.6\%; Vulpes and Urocyon) and mustelids (26.2\%; Hubbard et al. 1999). In Mississippi coyotes preyed upon adult turkeys (9.8\% of predation) but not as commonly as predators such as great-horned owls (17.6\%; Bubo virginianus) and bobcats (11.8\%; Lynx rufus; Miller et al. 1998).

Diets of coyotes west of the Mississippi River vary regionally. Some studies show low occurrences of vegetation (Korschgen 1957, MacCracken and Uresh 1984, Toweill and Anthony 1988), while others document high occurrences (Murie 1951, Best et al. 1981). Many studies note trends in seasonal diets (Korschgen 1957, Best et al. 1981, Toweill and Anthony 1988, Huebschman et al. 1997, Hidalgo-Mihart 2001). White-tailed deer and mule deer are often recorded in diets (Korschgen 1957, MacCracken and Uresh 1984, Toweill and Anthony 1988, Huebschman et al. 1997) as are cottontail rabbit species (Sylvilagus spp., hereafter rabbits; Korschgen 1957, MacCracken and Uresh 1984, Toweill and Anthony 1988, Hernández et al. 1994, Huebschman et al. 1997). In an early study of coyote food habits on a cattle range in Arizona, Murie (1951) found the highest occurring item to be juniper berries (Juniperus spp., $68 \%)$, with some occurrences of cattle (16\%) and small mammals (12\%).

In Montana, Reichel (1991) suggested that ungulate occurrence in diets was highest during fawning season. This is supported by Bowen (1980) in Alberta, Canada, who found deer occurring most during fawning season. Bowen (1980) grouped prey into size classes and 
determined the frequency of each size class in the scat: Class 4 prey $(31.0-450 \mathrm{~kg})$ ranked first at $49.5 \%$, Class 1 prey $(<100 \mathrm{~g})$ constituted $25.9 \%$, Class 3 prey $(1.2-30.0 \mathrm{~kg})$ occurred at $11.5 \%$, and Class 2 prey $(100-1100 \mathrm{~g})$ at $8.1 \%$.

Despite numerous studies involving coyote diets, few document diets long-term. One example is Young et al. (2006), who compared the results of two coyote diet studies on Welder Wildlife Refuge in Texas, one in 1978-1979 and one in 2003-2004. They found coyotes maintained similar diets between the 2 studies, though some variation in the amount of certain prey did change from 1978-1979 to 2003-2004 (Young et al. 2006).

Diet studies on coyotes east of the Mississippi River commonly report rodents, lagomorphs, and ungulates to be the most common food items in coyote diets (e.g., Silver and Koons 1972, Reichel 1991, Grogan 1996, Patterson et al. 1998, Gerads et al. 2001; Appendix A). Variability is common in the east as well as the west with some prey being more important regionally than others. Fruit, for example, in the Southeast is often an important food item (Gabor 1993, Stratman and Pelton 1997, Grigione 2011), whereas in the Northeast snowshoe hare (Lepus americanus) often dominates diets (Lapierre 1985, Moore and Millar 1986, Parker 1986).

Midwestern Diets. - Several studies have documented midwestern coyote diets. Midwestern diets commonly include white-tailed deer, snowshoe hare in the north, cottontail species, small mammals and fruit and vegetation. For instance, In Cuyahoga Valley, Ohio, Cepek (2004) found predominantly mammalian items (80\%) such as voles (Microtus spp.), eastern cottontail (Sylvilagus floridanus) and white-tailed deer. However, their results may be biased as they chose not to collect scat samples that visually contained plant material. 
Despite a small sample size (1 juvenile male, 1 juvenile female, and 1 adult male), Huegel and Rongstad (1985) observed radio-collared coyotes in their study in northern Wisconsin consumed mostly white-tailed deer. The adult male in the study consumed primarily snowshoe hare prior to mid-February before switching to white-tailed deer (Huegel and Rongstad 1985). In Wisconsin, Niebauer (1974) documented snowshoe hare, white-tailed deer, and rodents as the most commonly occurring items in coyote diets. He also noted the possibility of wild fruit acting as a buffer to predation on game animals such as deer (Niebauer 1974). In Wisconsin and Minnesota, Smith (1984), found deer occurrence in scats to vary among months with spring occurrence correlating with severity of the previous winter. Peaks in deer occurrence in scat were found during December-March and again in June during the deer fawning period. They also noted snowshoe hare occurrence in diet fluctuated with hare densities and that vegetation (e.g., seeds, fruit, buds, grasses) was important during the late summer and early fall (Smith 1984).

Ozoga and Harger (1966) found predominantly white-tailed deer in coyote diets in Michigan. When they visited kill sites they found most deer were scavenged. They also found high occurrence of apples and small mammals in diets (Ozoga and Harger 1966). In an urban study in Chicago, Morey et al. (2007) found human-developed areas to have more diverse diets than less human-developed areas. White-tailed deer, small rodents, fruit, rabbits, and birds dominated the diets of coyotes, but occurrence varied seasonally and between sites (Morey et al. 2007). In southern Illinois, Cypher (1993) found that during the summer, coyotes primarily consumed small rodents, birds, and June beetles (Phyllophaga spp.) with noted variation monthly, annually, and between upland and lowland sites. 
Mid-Atlantic Diets. - Mid-Atlantic diet studies are limited, but commonly include white-tailed deer, small mammals, plants material, fruit, and cottontail rabbits. The stomach of a coyote killed in Wayne County, West Virginia contained vegetables and persimmon seeds (Diospyros virginiana; Taylor et al. 1976) and was the first documented analysis of stomach contents in West Virginia. Wykle (1999) analyzed 24 stomachs of West Virginia coyotes collected during winter and documented white-tailed deer as the most common food item ( $83 \%$ of stomachs). Whether deer were scavenged or killed by the coyotes could not be determined (Wykle 1999). Wykle (1999) also recorded an unusually high percentage of plant material in winter with a $79 \%$ occurrence rate. These materials were often wood particles, and it was suggested that this was the result of coyotes chewing on surrounding trees and limbs while caught in leg-hold traps (Wykle 1999).

Similarly, in Pennsylvania Witmer et al. (1995) found white-tailed deer to be the most common item in coyote diets. Small mammals, plant material, fruit, rabbits, birds, insects and groundhogs (Marmota monax) occurred most commonly. They noted no livestock in diets, but did have some regional differences with samples in the northeast having higher occurrence of deer and rabbits whereas plant material and insects occurred more commonly in the south-central part of Pennsylvania (Witmer et al. 1995). Research on the winter diets of coyotes in Pennsylvania showed white-tailed deer (62.2\%) to be the most commonly occurring items followed by vegetation, rabbits, shrews and birds (Steinmann et al. 2011).

Southeastern Diets. - Southeastern coyote diet studies commonly report small mammals, cottontail species, white-tailed deer, livestock, and soft mast species such as persimmons. Coyotes in central Kentucky consume small mammals, rabbits, and livestock carrion in winter (Crossett and Elliott 1991). The winter diets of coyotes and red foxes 
(Vulpes vulpes) in central Kentucky were similar though red foxes tended to have higher occurrences of smaller items. Red foxes in Kentucky also fed less often on livestock than coyotes. Whether these differences were due to prey selection or red foxes being out-competed by coyotes is unknown (Crossett and Elliott 1991).

In Tennessee, Smith and Kennedy (1983) examined 54 digestive tracks from coyotes in the western part of the state and found predominantly rodents, livestock, plant material, and rabbits. Also in Tennessee, Gabor (1993) found fruit (44.8\%) and insects (20.3\%) dominated diets when available. White-tailed deer, small mammals, and rabbits were common in diets year-round with some seasonality having occurred. Studying coyote diets in Tennessee, Lee (1986) documented that male and female coyotes exhibited a high use of rodents (39\%) and rabbits (29\%) but also found white-tailed deer (27\%), livestock (17\%) and insects (13\%; primarily grasshoppers [Orthoptera]), as the other main components in coyote diets. Reptiles and amphibians, opossum (Didelphis virginiana), birds, and vegetation occurred at lower frequencies. Furthermore, Lee (1986) found miscellaneous human objects in the stomachs of coyotes including cloth, plastic and aluminum wrap, carpet, screen wire, Styrofoam and bubble gum. Grogan (1996) reported rabbits, small mammals, and white-tailed deer, but also found high occurrence of vegetation, especially persimmon, in coyote diets in Tennessee. Grogan's (1996) and Lee's (1986) findings suggest that southeastern coyotes are as opportunistic in their newly expanded range as in their historic range. The occurrence of agriculture crops, especially corn, was noted by Grogan (1996), as was the importance of persimmon in coyote diets where the trees were common. Additionally, Grogan (1996) suggested ungulate occurrence in coyote diets tends to be higher when carrion is available during fall hunting seasons. 
In Arkansas, Gipson (1974) found poultry to be the most common food item (34\%) in coyote diets. Maggots occurred in about $3 \%$ of stomachs containing poultry, suggesting some was scavenged carrion. Persimmons (23\%), insects (11\%) and rodents (9\%) were the other principle components of coyote diets (Gipson 1974). This study is one of the few that demonstrates high poultry occurrence in coyote diets in the eastern United States.

Owens (2006) studied coyote diets in northwestern Georgia and found rodents (56\%), rabbits (32\%), and deer (29\%) to be most frequently occurring items in scats collected from May 2005-August 2006. He also found substantial seasonal fluctuations with rodents occurring more in spring, vegetation occurring more in fall, and arthropods occurring fairly consistently throughout the year except during winter (Owens 2006). In South Carolina, Schrecengost et al. (2008) found soft mast to be the most occurring item in all months except December and March when white-tailed deer was the most common item. Schrecengost et al. (2008) also noted a high occurrence of fawns during May and June, despite low deer density, and suggested coyotes may be affecting deer recruitment (Schrecengost et al. 2008). Michaelson (1975) found rabbits, rodents, and persimmon to be important food items for coyotes in northwestern Louisiana. $\mathrm{He}$ also noted the possibility of rabbits, rodents, and armadillos (Dasypus novemcinctus) acting as buffers to livestock predation (Michaelson 1975).

Stratman and Pelton (1997) in northwestern Florida found shrub and vine fruit to be the most common item (80\%) in coyote diets, with beetles (55\%), persimmon (27\%), and whitetailed deer $(15 \%)$ constituting the next highest occurrences. They documented plant material comprised a substantial portion of coyote diets, a finding supported by other studies including Gipson (1974), Blanton and Hill (1989), and Gerads et al. (2001). Grigione et al. (2011) compared diets of coyotes on an urban-rural gradient in Florida. The commonly found items 
included vegetative matter, insects, lagomorphs, and berries, with more anthropogenic food sources in suburban diets compared to rural diets. They also documented rural diets were more diverse than suburban diets, although this difference was not statistically significant (Grigione et al. 2011). This is in contrast to Morey et al. (2007) who found coyotes in less-developed areas of suburban Chicago had less diverse diets. Thorton et al. (2004) compared diets of coyotes and bobcats in south-central Florida and found coyotes consumed more ungulates and fruit, whereas bobcats utilized rodents and lagomorphs more.

In Florida, Mississippi, Alabama, and Arkansas, Wagner and Hill (1994) evaluated the diets of coyotes during the reproductive season of wild turkeys. They found low occurrence of turkey in coyote diets on all study areas, but noted an increase (though not statistically significant) in its occurrence during the turkey reproductive season (Wagner and Hill 1994). Chamberlain and Leopold (1999) found coyote diets in Mississippi dominated by white-tailed deer, rabbits, and fruits. Wooding et al. (1984) examined coyote diets in Mississippi and Alabama and found rodents (43\%), fruit (39\%), and rabbits (35\%) as the 3 most common items during a 4-year study. VanGlider (2008) found predominantly small mammals, white-tailed deer, and plant material, with a peak of deer occurrence during fawning season in Alabama. In Mississippi, Alabama, Tennessee, and Kentucky, Blanton (1988) found fruit, insects, rabbit, deer, and rodents to be important foods for southeastern coyotes. Hoerath and Causey (1991) documented rodents (66\% frequency) as the most important food item in all seasons except fall when white-tailed deer dominated diets in central Alabama. The findings of Wooding et al. (1984) and Blanton (1988) support Patterson et al. (1998), who suggested soft mast occurrence in diets increases in late summer after fawning. 
Northeastern Diets. - Northeastern coyote diet studies commonly report white-tailed deer, snowshoe hare, fruits such as blueberries, and small mammals. Moore and Williamson (1975) in Ontario, Canada found rabbits to be the primary component of coyote diets, followed by voles. There was minimal livestock occurrence ( 3 cows, 2 pigs, 1 sheep), and only small amounts of deer present in scat (Moore and Williamson 1975). In Quebec, Samson and Crête (1997) documented the summer diets of coyotes in 1988 and 1991 and found groundhog and white-tailed deer dominated diets in 1988, while moose (Alces alces), snowshoe hare, and beaver (Castor canadensis) dominated in 1991. They also found high occurrence of berries (e.g., blueberries [Vaccinium spp.], serviceberries [Amelanchier spp.] and wild sarsaparilla [Aralia nudicaulis]) during summer (56\% in 1988 and 80\% in 1991; Samson and Crête 1997). Lapierre (1985) and Moore and Millar (1986) found snowshoe hare to predominate in coyote diets in New Brunswick, followed by white-tailed deer, and small mammals, with Moore and Milar (1986) noting high plant percent occurrence. This concurs with Parker (1986) who also found snowshoe hare to be most common during all seasons in coyote diets in New Brunswick. Parker (1986) also noted deer occurrence was more common during winter and spring, but not during summer when raspberries (Rubus spp.) and groundhog were important in diets. Dumond et al. (2001) also studied coyotes in New Brunswick, comparing seasonal diets between a protected (inside a National Park) and an unprotected (outside of the National Park) area. They documented seasonal changes in both areas, but only snowshoe hare was different seasonally between the two areas. They also noted the protected area had a lower proportion of mammals (60.3\% compared to $75.5 \%$ in unprotected) and a higher proportion of fruit and insects (20.8\% vs. $11.5 \%$; Dumond et al. 2001). 
In Maine, Hilton and Richens (1975) reported that snowshoe hare accounted for 34\%, white-tailed deer accounted for $54 \%$, and plant material accounted for $25 \%$ of the contents of coyote scat. Hilton and Richens (1975) also analyzed stomach contents and found white-tailed deer to be the most prevalent (33\%), followed by small mammals (27\%). Dibello et al. (1990) in Maine compared the diets of coyotes, red foxes, and bobcats. They found snowshoe hare, whitetailed deer, fruit, and vegetation to be the most commonly occurring items in diets. They noted hare was important to all species, but fruit was more important to coyotes in summer and deer was more important in winter (Dibello et al. 1990). In Maine, Harrison and Harrison (1984) analyzed scat of breeding coyotes and their known-age pups. They found blueberries to be the most commonly occurring item (68\%), followed by white-tailed deer, snowshoe hare, and small mammals. The high occurrence of fruit coincided with ripening of blueberries between JuneOctober. Deer and hare were more common in pup scat than adult scat, while small mammals were more common in adult scat (Harrison and Harrison 1984). O’Connell et al. (1992) studied food use of a population of coyotes on an island in Maine compared to a mainland population. Coyote on both the mainland and the island consumed predominantly white-tailed deer, fruit, and small mammals. However, coyotes on the island exhibited greater diet diversity than mainland coyotes, with raccoons (Procyon lotor) being more important to island coyotes than documented in previous studies, suggesting coyotes' ability to adapt to insular environments (O'Connell et al. 1992).

In New York, Pekins (1992) summarized 3 diet studies from the Adirondack region. He noted white-tailed deer was the dominant item in all 3 studies, though amounts varied from 39\%-94\% depending on study and year. Pekins (1992) suggested a shift in predation of coyotes toward deer over time in this region of New York, especially during winter months. Pekins 
(1992) review also noted diets of coyotes in contiguous forests were less diverse than those of coyotes from mixed-forest agriculture habitats. Hamilton (1974) found snowshoe hare, whitetailed deer, and fruit to be the most commonly occurring items from coyotes in the Adirondacks. He also noted the seasonal importance of insects and fruit and a decline in white-tailed deer occurrence during the summer months (Hamilton 1974). A more recent New York study by Boser (2009) examined diet and selection for white-tailed deer by coyotes. They found whitetailed deer was the dominant prey item during all seasons and fawn use was similar in areas of both high and low white-tailed deer density, suggesting coyotes were selecting for fawns. Based on backtracking (i.e., visiting sites with clusters of coyote activity, usually using GPS collar locations), most white-tailed deer at kill sites were scavenged and all livestock found were scavenged (Boser 2009).

\section{Coyotes and Livestock}

Coyotes are opportunistic omnivores that will prey upon livestock. In 2004, 385,000 lambs and 215,300 sheep were lost nationally to predator and nonpredator (e.g., disease, exposure) causes (USDA 2007). These totals represented $9.4 \%$ of the national lamb crop and $5.6 \%$ of the sheep inventory. Coyotes accounted for the highest percentage of predator losses, at $64.2 \%(247,170)$ of lambs, and $51.7 \%(111,310)$ of sheep nationally in 2004 (USDA 2007). In 2009 , the national loss of sheep and lambs to both predator and nonpredator causes rose to 400,000 lambs and 234,500 sheep (NASS 2010). In 2004, the National Agricultural Statistics Survey (NASS 2005) reported that $63.6 \%$ of sheep and lamb loss in West Virginia was the result of coyote predation (700 and 1,400 animals, respectively).

In 2010, 219,900 cattle and calves valued at 98.4 million dollars were lost to predators nationwide (NASS 2011). Coyotes account for $53.1 \%$ of these losses which were valued at 48.2 
million dollars (NASS 2011). In West Virginia no cattle were reported being lost to coyotes, but $1,300(86.7 \%)$ calves lost in West Virginia were attributed to coyotes in 2004 (NASS 2005). NASS $(1992,1996,2005)$ reported that losses to coyotes increased in West Virginia from less than 100 cattle and calves killed per year (reported in surveys) prior to 1995 to approximately 1,300 in 2004, likely due to increasing populations of coyotes in the state. The USDA APHIS Wildlife Services program spent $\$ 500,489$ on predator damage management activities in 2008 , with a direct benefit of $\$ 845,000$ to the West Virginia economy (Wildlife Services 2011). Sheep producers participating in the West Virginia Integrated Predation Management Program lost 131 sheep and lambs (an estimated \$24,230) during 2010 (Wildlife Services 2011). The Integrated Predation Management Program was initiated in 1996 to address increasing livestock losses to coyotes and incorporated direct control measures, technical assistance, and educational programs (Houben et al. 2004). In 2010, it supported direct control measures in 34 counties in West Virginia and 171 livestock producers (Wildlife Services 2011). Coyotes also were responsible for the loss of 15 adult and kid goats (valued at \$2,630), and 19 calves (valued at \$20,999) on the farms participating in the Integrated Predation Management Program in 2010 (Wildlife Services 2011).

Coyotes have also been known to prey upon swine (Fooks 1961, Alesandrini 1983, Jones and Woolf 1983, Slate 1987) and poultry (Korschgen 1957, Fooks 1961, Gipson 1974, Slate 1987). In Iowa, predation of sheep and swine were documented to be highest in summer, with calf losses highest during calving season (Boggess et al. 1978). Other damage to crops (e.g., stored feed, watermelons) (Jones 1987, Slate 1987, Connolly 1992, Philipp and Armstrong 1993), property (e.g., irrigation equipment, airports) and pets have been attributed to coyotes as well (Connolly 1992). 
Studies on the perceptions of ranchers have documented historic or perceived increases in coyote predation (e.g., Hafer and Hygnstrom 1991, Main et al. 2003), and show that many ranchers believe coyotes not only impact livestock but native wildlife as well (Philipp and Armstrong 1995, Main et al. 2003). Harrington and Conover (2007) suggested removal of coyotes to reduce livestock predation may also increase densities of wild ungulates. It has also been noted by Conover (2001) that hunting and trapping efforts to reduce wildlife damage increase landowner tolerance to coyote depredation.

Sacks and Neale (2002) suggested that coyotes do not prey upon sheep disproportionately to availability, despite the high nutritional value in sheep and lambs and relative local abundance in farm fields. Similarly, wolves in Minnesota were found to primarily consume native species despite high numbers of cattle available within their home range (Chavez and Gese 2005). In the Southeast, Jones (1987) reported that damage is often attributed to coyotes when in fact it is actually the result of feral dogs. Best et al. (1981) found high occurrence of livestock in diets and suggested that it may be a primary source of food for coyotes in central Oklahoma. Gier (1968) and Boggess et al. (1978) noted livestock losses paralleled the numbers of livestock in that area. Sacks and Neale (2002) also suggested predation on white-tailed deer decreased predation on sheep and lambs during certain seasons, while occurrence of lamb in diets increased during lambing season.

Studies suggest it is primarily breeding pairs that prey upon livestock (Connolly et al. 1976, Wagner and Conover 1999, Blejwas et al. 2006) and males are more likely to attack livestock than female coyotes (Connolly et al. 1976, Windberg et al. 1997, Blejwas et al. 2006). Coyotes provisioning pups in dens are thought to be major predators of livestock, especially lambs and goat kids (Till and Knowlton 1983). Till and Knowlton (1983) found that the removal 
of both adults and pups of paired coyotes reduced sheep losses by up to $98.8 \%$. They further suggest the possibility of sterilizing adult coyotes around sheep ranges to try to reduce predation (Till and Knowlton 1983). Bromley and Gese (2001) found sterilized coyotes maintained similar size territories and pair bonds as non-sterilized coyotes, suggesting sterilization as an alternative to removal of coyotes. However, sterilization requires capture of animals, locating dens of uncollared animals can be challenging, and such efforts may be cost prohibitive (Bromley and Gese 2001).

Control methods for coyotes vary but common methods include shooting, trapping, poisoning, husbandry practices and livestock-protection collars among others (see Fall 1990, Mitchell et al. 2004 for summaries). Conover (2001) suggests hunting and trapping can reduce wildlife damage by altering animal behavior. Guard dogs are used to protect flocks and herds in some areas (Green et al. 1984, Fall 1990), but purchasing, properly training, and keeping dogs can be cost prohibitive and often must be combined with other removal tactics (Green et al. 1984). Large-scale removal tactics (e.g., aerial hunting) are commonly used in the West (Guthery and Beasom 1977, Fall 1990, Wagner and Conover 1999, Mitchell et al. 2004), though success varies (Mitchell et al. 2004) and due to terrain differences aerial removal is not practical in the eastern United States. Windberg et al. (1997) advocated for local control of nuisance coyote populations. Some researchers and agencies have suggested the use of husbandry practices to reduce loss of livestock to predation, including lambing or calving in barns, night penning, predator-resistant fencing, and proper removal of carcasses (Jones and Woolf 1983, Tomsa and Forbes 1989, Fall 1990, Houben et al. 2004). Owens (1987) suggested livestock protection in the eastern United States can be challenging due to lack of public land, smaller percentage of land in agricultural crops, and when control is necessary, close proximity of 
neighbors that may not be supportive of removal efforts. Understanding the dynamics of coyote predation is an important component when dealing with losses of livestock.

\section{Food Habit Analysis Methodology}

Food habit studies are commonly used to study wildlife populations (Kohn and Wayne 1997). Reports of food habit studies in the United States date back to the 1800s and primarily focused on birds (Korschgen 1969). Korschgen's $(1969,1980)$ chapter in the Wildlife Management Techniques manual explains procedures for conducting food habit analyses, many of which are still used today. Biases in food habits studies have been addressed by several studies including Andelt and Andelt (1984), Mersmann (1992), Marucoo et al. (2008), and Klare et al. (2011).

Direct observation is one means of assessing food habits, though this technique is labor intensive and often not feasible with cryptic or nocturnal species (Mersmann et al. 1992). Collecting samples to analyze in a laboratory setting is more common and easily accomplished. Generally samples for food habit studies are of 2 primary types: (1) stomach contents and (2) feces (Korschgen 1969, 1980). Anthony and Smith (1974) compared analyses of stomach and fecal samples in white-tailed and mule deer. They found analyses yielded similar results and suggest both are useful to diet studies (Anthony and Smith 1974).

There are 3 basic methods for storing samples before processing: (1) wet, such as in formalin, (2) dry, and (3) frozen (Korschgen 1980). Generally, freezing is most common as this preserves samples long term and allows for samples to be used for genetic analysis (Roon et al. 2003). Basic initial steps include hand washing of samples (if necessary) through a mesh sieve or in a bag in an automatic washing machine, then drying in a drying oven or commercial drier. Often, only a portion of each sample is used to allow for additional testing or re-analysis if data 
is lost (Korschgen 1980). Temperatures and times for drying vary by species. After drying, samples are separated, usually using forceps, decanting materials, or centrifuging (Korschgen 1980).

After separation, materials are identified (Korschgen 1980). Identification can be aided by guides such as those for mammalian hair by Spence (1963), Moore et al. (1974), Teerink (1991), and De Marinis and Asprea (2006) and guides for feathers such as Dove and Koch (2010). Keys to seeds, plants and invertebrates are commonly used as well, depending on the species being studied. Reference collections (e.g., museum collections, vegetation sampling from study sites) are also necessary to help identify contents during food habit analysis (Korschgen 1980).

Dissecting microscopes are sometimes needed to identify seeds, invertebrates, small mammal skulls, and other small items (Korschgen 1980). Compound microscopes are necessary for hair identification (Spence 1963, Moore et al. 1974). Hair can be identified by examining the patterns of the medulla (inside layer) or the scalar pattern on the cortex (outside layer) (Moore et al. 1974, Korschgen 1980). To examine the hair, a few strands must be separated and mounted to a microscope slide using a clear binding agent such as fingernail polish, xylene, or a similar material. Scale patterns are examined by allowing hair to dry in the material, then pulling the strand free, which leaves an impression in the medium. Medullar patterns can be analyzed by covering hair with a cover slip and examining under a microscope (Spence 1963, Moore et al. 1974, Teerink 1991). Cross-sections of hair can also be useful in identification (Teerink 1991, De Marinis and Asprea 2006), as can color banding (Moore et al. 1974). Compound microscopes are also needed to identify presence and shape of barbules on feathers after being mounted on a microscope slide in a similar manner to hair (Dove and Koch 2010). DNA of prey 
items present in diets can be used as well, though this method is often cost-prohibitive and crosscontamination is possible (Barrett et al. 2007).

Frequency of occurrence is the most common method of reporting results of food habit analyses (Korschgen 1980, Corbett 1989, Van Dijk et al. 2007). Frequency of occurrence is obtained by dividing the number of samples containing a certain item by the total number of samples. This method is simple, straight-forward, and easily compared among studies (Corbett 1989). Volume of items in diets is also commonly reported. There are two common methods of determining volume, though other, less frequently used methods do exist (Korschgen 1980). Visual estimation is one method used to estimate volume and requires the observer to separate each item in samples and then estimate percent volume of that item. This method can be subject to observer bias and variation if multiple observers are analyzing samples (Korschgen 1980). Another method is the point-frame method (Chamrad and Box 1964). This method utilizes a grid that is laid over the sample to determine how often an item occurs at a vertex. Another variation drops pins from the vertices into the sample to determine items present (Chamrad and Box 1964). Point-frame has been suggested to reduce observer bias and handling time of samples (Ciucci et al. 2004), though it can underestimate small or trace items in samples and proper mixing of the sample is necessary to minimize biases (Chamrad and Box 1964). Other analyses such as dry weights of items in diets or using an index of relative contribution have been used in studies, but have not been shown to reflect diets as accurately as other analyses (Van Dijk et al. 2007).

Some studies use or suggest conversion factors to convert dry matter mass to mass of item consumed by the animal, or biomass (Putnam 1984, Corbett 1989, Rühe et al. 2008, Klare 2011). Although this estimation can be important to management because it allows for 
estimation of numbers or size of animals consumed by predators, these analyses can exhibit problems and biases. Often, the conversion factors are based on feeding trials rather than realworld situations and many species have not had sufficient studies conducted to accurately estimate conversions (Rühe et al. 2008, Klare 2011). It also is usually only practical for species with limited range in diet; the more diverse the diet the more difficult this conversion becomes (Putman 1984). Reynolds and Aebischer (1991) point out that adult and juvenile digestion rates differ and conversion factors of prey items (for carnivores) are related to body size of the prey.

One drawback of food habit studies is observer error (Spaulding et al. 2000). Often, several workers are involved in processing and it is possible for items in diets to be misidentified (Spaulding et al. 2000). Another problem with food habit analysis is differential digestibility of items since some items may stay in stomachs much longer than others (Putnam 1984, Reynolds and Aebischer 1991, Mersmann et al. 1992). For example, Reynolds and Aebischer (1991) suggested that bird remains do not preserve through digestion as do mammalian hairs, which could lead to underestimation of birds in diets. It is possible for some items to be under-estimated in samples either due to observer error (Mersman et al. 1992, Bartolomé et al. 1995), or lack of identifiable material (Putnam 1984). Food habits studies also give limited information about diets because they often represent only one day's worth of items in a sample (Putman 1984).

New techniques to examine food habits are being developed as technology advances. Stable isotope analysis is one such method. This method uses various isotopes to determine diets of species of interest (Gannes 1997, Hobson 1999). Generally, hair samples are taken from the species being studied and isotopes (primarily $\delta^{13} \mathrm{C}, \delta^{15} \mathrm{~N}, \delta^{34} \mathrm{~S}, \delta \mathrm{D}, \delta^{87} \mathrm{Sr}$ ) are analyzed. This method can be used to determine diets between food webs, analyze migration patterns, link 
species to geographic origins, and determine relative contribution of items in an animal's diet (Gannes 1997, Hobson 1999). One of the challenges of this approach is isotopic compositions in tissues can differ from diet (Gannes 1997). One positive aspect is researchers can get a more long-term analysis of diets (generally several months) from hairs or tissues (Hobson 1999). However, identifying items to species can be challenging and generally only categories of items may be used (Ben-David et al. 1997, Phillips 2001). 


\section{LITERATURE CITED}

Alesandrini, J. A. 1983. Winter food habits of coyote in central Illinois. Thesis, Illinois State University, Bloomington, USA.

Andelt, W. F., and S. H. Andelt. 1984. Diet bias in scat deposition-rate surveys of coyote density. Wildlife Society Bulletin 12:74-77.

Andelt, W. F., K. Cardwell, J. G. Kie, and F. F. Knowlton. 1987. Variation in coyote diets associated with season and successional changes in vegetation. Journal of Wildlife Management 51:273-277.

Anthony, R. G., and N. S. Smith. 1974. Comparison of rumen and fecal analysis to describe deer diets. Journal of Wildlife Management 38:535-540.

Barrett, R. T., C. J. Kees, Y. Anker-Nilssen, J. W. Chardine, R. W. Furness, S. Garthe, O. Hüppop, M. F. Leopold, W. A. Montevecchi, and R. R. Veit. 2007. Diet studies of seabirds: a review and recommendations. Journal of Marine Science 64:1675-1691.

Bartmann, R. M., G. C. White, and L. H. Carpenter. 1992. Compensatory mortality in a Colorado mule deer population. Wildlife Monographs 121.

Bartolomé, J., J. Franch, M. Hutman, and N. Seligman. 1995. Physical factors that influence fecal analysis estimates of herbivore diets. Journal of Range Management 48:267-270.

Bekoff, M., and E. M. Gese. 2003. Coyote (Canis latrans). Pages 467-481 in G.A. Feldhammer, C. Thompson, J. A. Chapman (editors). Wild Mammals of North America: Biology, Management, and Conservation. Second edition. Johns Hopkins University Press, Baltimore, Maryland, USA.I 
Ben-David, M., T. A. Hanley, D. R. Klein, and D. M. Schell. 1997. Seasonal changes in diets of coastal and riverine mink: the role of spawning Pacific salmon. Canadian Journal of Zoology 75:803-811.

Best, T. L., B. Hoditschek, and H. H. Thomas. 1981. Foods of coyotes (Canis latrans) in Oklahoma. The Southwestern Naturalist 26:67-69.

Bishop, C. J., G. C. White, D. J. Freddy, B. E. Watkins, and T. R. Stephenson. 2009. Effect of enhanced nutrition on mule deer population rate of change. Wildlife Monographs 172.

Blanton, K. 1988. Summer diet of coyotes in the southeast, and the response of coyotes to siren surveys. Thesis, Mississippi State University, Starkville, USA.

Blanton, K. M., and E. P. Hill. 1989. Coyote use of white-tailed deer fawns in relation to deer density. Proceedings of the Annual Conference of Southeastern Association of Fish and Wildlife Agencies 43:470-478.

Blejwas, K. M., C. L. Williams, G. T. Shin, D. R. McCullough, and M. M. Jaeger. 2006. DNA evidence convicts breeding male coyotes of killing sheep. Journal of Wildlife Management 70:1087-1093.

Boggess, E. K., R. D. Andrews, and R. A. Bishop. 1978. Domestic animal losses to coyote and dogs in Iowa. Journal of Wildlife Management 42:362-372.

Boser, C. L. 2009. Diet and hunting behavior of coyotes in agricultural-forest landscapes of New York State. Thesis, State University of New York College of Environmental Science and Forestry, Syracuse, USA.

Bowen, W. D. 1980. Variation in coyote social organization: the influence of prey size. Canadian Journal of Zoology 59:639-652. 
Bozarth, C. A., F. Hailer, L. L. Rockwood, C. W. Edwards, and J. E. Maldonado. 2011. Coyote colonization of northern Virginia and admixture with Great Lakes wolves. Journal of Mammalogy 92:1070-1080.

Bromley, C., and E. M. Gese. 2001. Effects of sterilization on territory fidelity and maintenance, pair bonds, and survival rates of free-ranging coyotes. Canadian Journal of Zoology 79:386-392.

Carpenter, M. 1971. Some recent coyote records in Virginia. Virginia Wildlife 32:14-15.

Cepek, J. D. 2004. Diet composition in the Cuyahoga Valley National Park, Ohio. Ohio Journal of Science 104:60-64.

Chamberlain, M. J., and B. D. Leopold. 1999. Dietary patterns of sympatric bobcats and coyotes in Central Mississippi. Proceedings of the Southeastern Association of Fish and Wildlife Agencies 53:204-219.

Chamrad, A. D., and T. W. Box. 1964. A point frame for sampling rumen contents. Journal of Wildlife Management 28:473-477.

Chavez, A. S., and E. M. Gese. 2005. Food habits of wolves in relation to livestock depredations in Northwestern Minnesota. American Midland Naturalist 154:253-263.

Ciucci, P., E. Tosoni, and L. Boitani. 2004. Assessment of the point-frame method to quantify wolf Canis lupus diet by scat analysis. Wildlife Biology 10:149-153.

Compton, T. L. 1980. Coyote predation on an adult deer in Southwestern Colorado. The Southwestern Naturalist 25:113-114.

Connolly, G. 1992. Colonization by the eastern coyote (Canis latrans). Pages 162-169 in Boer, A. (editor). Ecology and Management of the Eastern Coyote. Wildlife Research Unit, University of New Brunswick, Fredericton, Canada. 
Connolly, G. E., R. M. Timm, W. E. Howard, and W. M. Longhurst. 1976. Sheep killing behavior of captive coyotes. Journal of Wildlife Management 40:400-407.

Conover, M. R. 2001. Effect of hunting and trapping on wildlife damage. Wildlife Society Bulletin 29:521-532.

Corbett, L. K. 1989. Assessing the diet of dingoes from feces: a comparison of 3 methods. Journal of Wildlife Management 53:343-346.

Crossett, R. L., and C. L. Elliott. 1991. Winter food habits of red foxes and coyotes in central Kentucky. Proceedings of the Annual Conference of Southeastern Association of Fish and Wildlife Agencies 45:97-103.

Cypher, B. L., A. Woolf, and D. C. Yancy. 1993. Summer food habits of coyotes at Union County Conservation Area, Illinois. Transactions of the Illinois State Academy of Science 86:145-152.

De Marinis, A. M., and A. Asprea. 2006. Hair identification of wild and domestic ungulates from southern Europe. Wildlife Biology 12:305-320.

Dibello, F. J., S. M. Arthur, and W. B. Krohn. 1990. Food habits of sympatric coyotes, Canis latrans, red foxes, Vulpes vulpes, and bobcats, Lynx rufus, in Maine. Canadian Field Naturalist 104:403-408.

Dove, C. J., and S. L Koch. 2010. Microscopy of feathers: A practical guide for forensic feather identification. Journal of the American Society of Trace Evidence Examiners 1:15-61.

Dumond, M., M. Villard, E. Tremblay. 2001. Does coyote diet vary seasonally between a protected and an unprotected forest landscape? Ecoscience 8:301-310.

Fall, M. W. 1990. Control of coyote predation on livestock-progress in research and development. Proceedings of the Fourteenth Vertebrate Pest Conference. 14:45-251. 
Fedriani, J. M., T. K. Fuller, and R. M. Sauvajot. 2001. Does availability of anthropogenic food enhance densities of omnivorous mammals? An example with coyotes in southern California. Ecography 24:325-331.

Fooks, L. G. 1961. Food habits of indigenous Canidae and Felidae in Arkansas based on complete and sample analyses of stomach contents. Thesis, University of Arkansas, Fayetteville, USA.

Gabor, T. M. 1993. An assessment of the feeding ecology of coyotes in Western Tennessee. Thesis, University of Memphis, Tennessee, USA.

Gannes, L. Z., D. M. O’Brien, and C. M. del Rio. 1997. Stable isotopes in animal ecology: assumptions, caveats, and a call for more laboratory experiments. Ecology 78:12711276.

Gerads, J. R., J. A. Jenks, and B. K. Watters. 2001. Food habits of coyotes inhabiting the Black Hills and surrounding prairies in western South Dakota. Proceedings of the South Dakota Academy of Science 80:95-108.

Gese, E. M. 2004. Coyotes in Yellowstone National Park: the influence of dominance on foraging, territoriality, and fitness. Pages 271-284 in W. MacDonald and C. SilleroZubiri (editors). The Biology and Conservation of Wild Canids. Oxford University Press, Oxford, United Kingdom.

Gese, E. M., and S. Grothe. 1995. Analysis of coyote predation on deer and elk during winter in Yellowstone National Park, Wyoming. American Midland Naturalist 133:36-43.

Gese, E. M., O. J. Rongstad, and W. R. Mytton. 1988. Relationship between coyote group size and diet in southeastern Colorado. Journal of Wildlife Management 52:647-653. 
Gier, H. T. 1968. Coyotes in Kansas. Kansas State College Agriculture Experimental Station Bulletin 393, Manhattan, USA.

Gipson, P. S. 1974. Food habits of coyotes in Arkansas. Journal of Wildlife Management $38: 848-853$.

Gipson, P. S. 1978. Coyotes and related Canis in the southeastern United States with a comment on Mexican and Central American Canis. Pages 191-208 in M. Bekoff, editor. Coyotes: Biology, behavior, and management. The Blackburn Press, Caldwell, New Jersey, USA.

Green, J. S., R. A. Woodruff, and T. T. Tueller. 1984. Livestock-guarding dogs for predator control: costs, benefits, and practicality. Wildlife Society Bulletin 23:44-50.

Grigione, M. M., P. Burman, S. Clavio, S. J. Harper, D. Manning, R. J. Sarno. 2011. Diet of Florida coyotes in a protected wildlife and suburban habitat. Urban Ecosystems.

Grogan, M. E. 1996. Feeding strategies of the coyote (Canis latrans) in western Tennessee. Thesis, University of Memphis, Tennessee, USA.

Guthery, F. S., and S. L. Beasom. 1977. Responses of game and nongame wildlife to predator control in South Texas. Journal of Range Management 30:404-409.

Hafer, D. J., and S. E Hygnstrom. 1991. Attitudes of Nebraska sheep producers toward predators. Proceedings $10^{\text {th }}$ Great Plains Wildlife Damage Conference 10:57-60.

Hamilton, Jr., W. J. 1974. Food habits of the coyote in the Adirondacks. New York Fish and Game Journal 21:177-181.

Harrington, J. L., and M. R. Conover. 2007. Does removing coyotes for livestock protection benefit free-ranging ungulates? Journal of Wildlife Management 71:1555-1560. 
Harrison, D. J. and J. A. Harrison. 1984. Foods of adult Maine coyotes and their known-aged pups. Journal of Wildlife Management 48:922-926.

Henke, S. E. 2002. Coyotes: Friend or foe of northern bobwhite in southern Texas. Pages 5760 in S. J. DeMaso, W. P. Kuvlesky, Jr., F. Hernandez, and M. E. Berger, editors. Quail V: Proceedings of the Fifth National Quail Symposium. Texas Parks and Wildlife Department, Austin, TX.

Hernández, L., M. Delibes, F. Hiraldo. 1994. Role of reptiles and arthropods in the diet of coyotes in extreme desert areas of northern Mexico. Journal of Arid Environments 26:165-170.

Hidalgo-Mihart, M. G., L. Cantu-Salazer, C. A. Lopez-Gonzalez, E. Martinez-Meyer, A. Gonzalez-Romero. 2001. Coyote (Canis latrans) food habits in a tropical deciduous forest of Western Mexico. American Midland Naturalist 146:201-216.

Hill, E. P., P. W. Sumner, and J. B. Wooding. 1987. Human influences on range expansion of coyotes in the Southeast. Wildlife Society Bulletin 15:521-524.

Hilton, H., and V. Richens. 1975. Coyote food habits and prey relationships in Maine. Pages 74-82 in Transactions of the Eastern Coyote Workshop. R.E. Chambers, editor. Northeast Fish and Wildlife Conference, 23-26 February 1975, New Haven, Connecticut, USA.

Hilton, H. 1978. Systematics and ecology of the eastern coyote. Pages 209-228 in M. Bekoff, editor. Coyotes: biology, behavior, and management. The Blackburn Press, Caldwell, New Jersey. USA.

Hobson, K. A. 1999. Tracing origins and migration of wildlife using stable isotopes: a review. Oecologia 120:314-326. 
Hoerath, J. D., and M. K. Causey. 1991. Seasonal diets of coyotes in western central Alabama. Proceedings of the Annual Conference of Southeastern Association of Fish and Wildlife Agencies 45:91-96.

Houben, J. M., W. R. Bonwell, and T. R. McConell. 2004. Development of the West Virginia Integrated Predation Management Program to protect livestock. Proceedings of the Vertebrate Pest Conference 21:71-74.

Hubbard, M. W., D. L. Garner, E. E. Klaas. 1999. Wild turkey poult survival in Southcentral Iowa. The Journal of Wildlife Management 63:199-203.

Huebschman, J. J., S. E. Hygnstrom, and J. A. Gubanyi. 1997. Coyote food habits at DeSoto National Wildlife Refuge, Nebraska. The Prairie Naturalist 29:99-109.

Huegel, C. N., and O. J. Rongstad. 1985. Winter foraging patterns and consumption rates of Northern Wisconsin coyotes. American Midland Naturalist 113:203-207.

Jackson, A. M. 2011. Survival estimates of white-tailed deer fawns at Fort Rucker, Alabama. Thesis, Auburn University, Alabama, USA.

Jones, E. J. 1987. Coyote damage in the southeastern United States. Proceedings of the Eastern Wildlife Damage Control Conference 3:320.

Jones, J. M., and A. Woolf. 1983. Relationship between husbandry practices and coyote use of swine in west central Illinois. Wildlife Society Bulletin 11:133-135.

Kays, R., A. Curtis, and J. Kirchman. 2010. Rapid adaptive evolution of northeastern coyotes via hybridization with wolves. Biology Letters 6:89-93.

Kilgo, J. C., H. S. Ray, C. Ruth, and K. V. Miller. 2010. Can coyotes affect deer populations in southeastern North America. Journal of Wildlife Management 74:929-933. 
Klare, U., J. F. Kamler, and D. W. Macdonald. 2011. A comparison and critique of different scat-analysis methods for determining carnivore diet. Mammal Review 41:294-312.

Kohn, M. H., and R. K. Wayne. 1997. Facts from feces revisited. Trends in Ecology and Evolution 12:223-227.

Korschgen, L. J. 1957. Food habits of the coyote in Missouri. The Journal of Wildlife Management 21:424-435.

Korschgen, L. J. 1969. Procedures for food habit analysis. Pages 233-250 in R.H. Giles, Jr., (editor). Wildlife Management Techniques. The Wildlife Society, Washington, D.C., USA.

Korschgen, L. J. 1980. Procedures for food habit analysis. Pages 113-127 in S. D. Schemnitz, (editor). Wildlife Management Techniques. The Wildlife Society, Washington, D.C., USA.

Laliberte, A. S., and W. J. Ripple. 2004. Range contractions of North American carnivores and ungulates. BioScience 54:123-138.

Lamont, M. M., H. F. Percival, L. G. Pearlstine, S. V. Colwell, and R. R. Carthy. 1998. Sea turtle nesting activity along Eglin Air Force Base on Cape San Blas and Santa Rosa Island, Florida from 1994 to 1997. U.S.G.S. Biological Resources Division, Florida Cooperative Fish and Wildlife Research Unit Technical Report No. 59.

Lapierre, L. E. 1985. Fall and winter food habits of the eastern coyote Canis latrans in southeastern New Brunswick. Proceedings of the Nova Scotian Institute of Science $35: 71-74$.

Lavigne, G. R. 1992. Sex/age composition and physical condition of deer killed by coyotes during winter in Maine. Pages 141-160 in Boer, A. (editor). Ecology and Management 
of the Eastern Coyote. Wildlife Research Unit, University of New Brunswick, Fredericton, Canada.

Lee, R. M. 1986. Food habits of the coyote, Canis latrans, in Tennessee. Thesis, Memphis State University, Tennessee, USA.

Lingle, S. 2000. Seasonal variation in coyote feeding behaviour and mortality of white-tailed deer and mule deer. Canadian Journal of Zoology 78:85-99.

Litvaitis, J. A., and W. M. Mautz. 1980. Food and energy use by captive coyotes. Journal of Wildlife Management 44:56-61.

MacCracken, J. G., and R. M. Hansen. 1982. Seasonal foods of coyotes in southeastern Idaho: A multivariate analysis. Great Basin Naturalist 42:45-49.

MacCracken, J. G., and D. W. Uresh. 1984. Coyote foods in the Black Hills, South Dakota. Journal of Wildlife Management 48:1420-1423.

Main, M. B., M. D. Fanning, J. J. Mullahey, S. Coates, and D. H. Thornton. 2003. Cattlemen's perceptions of coyote in Florida. Biological Sciences 66:55-62.

Marucco, F., D. H. Pletcher, and L. Boitani. 2008. Accuracy of scat sampling for carnivore diet analysis: wolves in the alps as a case study. Journal of Mammalogy 89:665-673.

McGinnis, H. J. 1979. Pennsylvania Coyotes and their relationship to other wild Canis populations in the Great Lakes region and the northeastern United States. Thesis, Pennsylvania State University, State College, PA, USA.

Mersmann, T. J., D. A. Buehler, A. D. Fraser, and A. K. D. Seegar. 1992. Assessing bias in studies of bald eagle food habits. Journal of Wildlife Management 56:73-78.

Messier, F., C. Barrette, and J. Huot. 1986. Coyote predation on a white-tailed deer population in southern Quebec. Canadian Journal of Zoology 64:1134-1136. 
Michaelson, K. A. 1975. Food habits of coyotes in northwest Louisiana. Thesis, Louisiana Tech University, Ruston, USA.

Miller, D. A., L. W. Burger, B. D. Leopold, and G. A. Hurst. 1998. Survival and cause-specific mortality of wild turkey hens in Central Mississippi. Journal of Wildlife Management 62:306-313.

Mitchell, B. R., M. M. Jaeger, R. H. Barrett. 2004. Coyote depredation management: Current methods and research needs. Wildlife Society Bulletin 32:1209-1218.

Moore, T. D., C.E. Dugnolle, and L. E. Spence. 1974. Identification of the dorsal guard hairs of some mammals of Wyoming. Wyoming Game and Fish Department Bulletin No. 14. Cheyenne, Wyoming, USA.

Moore, G. C., and J. S. Millar. 1986. Food habits and average weights of a fall-winter sample of eastern coyotes, Canis latrans. Canadian Field Naturalist 100:105-106.

Moore, G. C., and G. R. Parker. 1992. Colonization by the eastern coyote (Canis latrans). Pages 23-37 in Boer, A. (editor). Ecology and Management of the Eastern Coyote. Wildlife Research Unit, University of New Brunswick, Fredericton, Canada.

Moore, W. J., and J. C. Williamson. 1975. Food habits and morphometry of coyotes in Ontario’s Prince Edward County. Pages 68-73 in Transactions of the Eastern Coyote Workshop. Northeast Fish and Wildlife Conference, 23-26 February 1975, New Haven, Connecticut, USA.

Morey, P. S., E. M. Gese, and S. Gehrt. 2007. Spatial and temporal variation in the diet of coyotes in the Chicago metropolitan area. American Midland Naturalist 158:147-161. Murie, A. 1951. Coyote food habits on a southwestern cattle range. Journal of Mammalogy $32: 291-295$. 
Muntz, E. M., and B. R. Patterson. 2004. Evidence for the use of vocalization to coordinate the killing of a white-tailed deer, Odocoileus virginianus, by coyotes, Canis latrans.

National Agricultural Statistics Service [NASS]. 1992. Cattle and calf predator loss. National Agriculture Statistics Service. United States Department of Agriculture, Washington, D.C., USA.

NASS. 1996. Cattle and calf predator loss. National Agriculture Statistics Service. United States Department of Agriculture, Washington, D.C., USA.

NASS. 2005. Cattle and calf predator loss. National Agriculture Statistics Service. United States Department of Agriculture, Washington, D.C., USA.

NASS. 2010. Sheep and goats death loss. National Agriculture Statistics Service. United States Department of Agriculture, Washington, D.C., USA.

NASS. 2011. Cattle and calf predator loss. National Agriculture Statistics Service. United States Department of Agriculture, Washington, D.C., USA.

Niebauer, T. J. 1974. Coyote food habits in northwestern Wisconsin. Thesis, University of Wisconsin, Madison, USA.

Nowak, R. M. 1978. Systematics and ecology of the eastern coyote. Pages 209-228 in M. Bekoff, editor. Coyotes: biology, behavior, and management. The Blackburn Press, Caldwell, New Jersey. USA.

Nowak, R. M. 1979. North American Quaternary Canis. Monograph of the Museum of Natural History, University of Kansas No. 6, Lawrence, USA.

O’Connell Jr., A. F., D. J. Harrison, B. Connery, and K. B. Anderson. 1992. Food use by an insular population of coyotes. Northeast Wildlife 49:36-42. 
Owens, R. D. 1987. Coyote control techniques and their applications in the Eastern United States. Proceedings of the Eastern Wildlife Damage Control Conference 3:323-224.

Owens, K. M. 2006. Seasonal dietary composition of the eastern coyote (Canis latrans) on the Berry College campus in northwestern Georgia. Thesis, University of Tennessee, Chattanooga, USA.

Ozoga, J. J., and E. M. Harger. 1966. Winter activities and feeding habits of northern Michigan coyotes. Journal of Wildlife Management 30:809-818.

Paisley, R. N., R. G. Wright, J. F. Kubisiak, R. E. Rolley. 1998. Reproductive ecology of the eastern wild turkey in Southwestern Wisconsin. The Journal of Wildlife Management 62:911-916.

Parker, G. R. 1986. Food habits and average weights of a fall-winter sample of eastern coyotes, Canis latrans. Canadian Field Naturalist 100:74-77.

Parker, G. R. 1995. Eastern Coyote: The story of its success. Nimbus Publishing, Halifax, Nova Scotia, Canada.

Patterson, B. R., L. K. Benjamin, and F. Messier. 1998. Prey switching and feeding habits of eastern coyotes in relation to snowshoe hare and white-tailed deer densities. Canadian Journal of Zoology 76:1885-1897.

Patterson, B. R., B. A. MacDonald, B. A. Lock, D. G. Anderson, and L. K. Benjamin. 2002. Proximate factors limiting population growth of white-tailed deer in Nova Scotia. Journal of Wildlife Management 66:511-521.

Patterson, B. R., and F. Messier. 2000. Factors influencing killing rates of white-tailed deer by coyotes in Eastern Canada. Journal of Wildlife Management 64:721-732. 
Patterson, B. R., and F. Messier. 2001. Social organization and space use of coyotes in Eastern Canada relative to prey distribution and abundance. Journal of Mammalogy 82:463-477.

Patterson, B. R., and F. Messier. 2003. Age and condition of deer killed by coyotes in Nova Scotia. Canadian Journal of Zoology 81:1894-1898.

Pekins, P. J. 1992. Winter diet and bioenergetics of eastern coyotes: a review. Pages 87-100 in Boer, A. (editor). Ecology and Management of the Eastern Coyote. Wildlife Research Unit, University of New Brunswick, Fredericton, Canada.

Phillips, D. L. 2001. Models in analyses of diet using multiple stable isotopes: A critique. Oecologia 127:166-170.

Philipp, M. C., and J. B. Armstrong. 1995. Perceptions knowledge of Alabama fruit and vegetable producers towards coyotes. Proceedings of the Eastern Wildlife Damage Control Conference 6:175-181

Piccolo, B. P., T. R. Van Deelen, K. Hollis-Etter, R. E. Warner, and C. Anchor. 2010. Behavior and survival of white-tailed deer neonates in two suburban forest preserves. Canadian Journal of Zoology 88:487-495.

Pruner, R. A. 2010. Conservation and management of the snowy plover along the Florida Gulf Coast: Habitat selection and the consequent reproductive performance. Thesis, The University of Florida, Gainesville, USA.

Putman, R. J. 1984. Facts from faeces. Mammal Review 14:79-97.

Quinn, T. 1997. Coyote (Canis latrans) Food habits in three urban habitat types of western Washington. Northwest Science 71:1-5.

Reichel, J. 1991. Relationships among coyote food habits, prey populations, and habitat use. Northwest Science 65:133-137. 
Reynolds, J. C., and N. J. Aebischer. 1991. Comparison and quantification of carnivore diet by faecal analysis: a critique, with recommendations, based on a study of the Fox Vulpes vulpes. Mammal Review 21:97-122.

Rohm, J. H., C. K. Nielsen, and A. Woolf. 2007. Survival of white-tailed deer fawns in Southern Illinois. Journal of Wildlife Management 71:851-860.

Roon, D. A., L. P. Waits, and K. C. Kendall. 2003. A quantitative evaluation of two methods for preserving hair samples. Molecular Ecology Notes 3:163-166.

Rühe, F., M. Ksinsik, and C. Kiffner. 2008. Conversion factors in carnivore scat analysis: sources of bias. Wildlife Biology 14:500-506.

Saalfeld, S. T., and S. S. Ditchkoff. 2007. Survival of neonatal white-tailed deer in an exurban population. Journal of Wildlife Management 71:940-944.

Sacks, B. N., and J. C. C. Neale. 2002. Foraging strategy of a generalist predator toward a special prey: coyote predation on sheep. Ecological Applications 12:299-306.

Sacks, B. N., and J. C. C. Neale. 2007. Coyote abundance, sheep predation, and wild prey correlates illuminate Mediterranean trophic dynamics. Journal of Wildlife Management 71:2404-2411.

Samson, C. and M. Crete. 1997. Summer food habits and population density of coyotes, Canis latrans, at the Savannah River Site, South Carolina. Thesis, University of Georgia, Athens, USA.

Schrecengost, J.D., J. C. Kilgo, D. Mallard, H. S. Ray, and K. V. Miller. 2008. Seasonal food habits of the coyote in the South Carolina coastal plain. Southeastern Naturalist 7:135144. 
Sheldon, J. W., G. Reed, A. C. Burnett, K. Li, and R. L. Crabtree. 2009. Coyote, Canis latrans, predation on a bison, Bison bison, calf in Yellowstone National Park. Canadian Field Naturalist 123:260-261.

Silver, H., and G. Koons. 1972. Friend or Foe? New Hampshire Outdoorsman March:18-20.

Slate, D. L. 1987. Coyotes in the Eastern US: Status and implications. Proceedings of the Eastern Wildlife Damage Control Conference 3:325-326.

Smith, G. J. 1984. Coyote ecology in northern Wisconsin and Minnesota. Dissertation, University of Wisconsin, Madison, USA.

Smith, R. A., and M. L. Kennedy. 1983. Food habits of the coyote (Canis latrans) in Western Tennessee. Journal of the Tennessee Academy of Science 58:27-28.

Spaulding, R., P. R. Krausman, and W. B. Ballard. 2000. Observer bias and analysis of gray wolf diets from scats. Wildlife Society Bulletin 28:947-950.

Spence, L. E. 1963. Study for identifying characteristics of mammal hair. Wyoming Game and Fish Commission Job Completion Report Project FW 3-R-10, Work Plan No. 10, Job No. 2W, Laramie, USA.

Steinmann, K. W., M. J. Cegelski, P. R. Delis, R. L. Stewart Jr. 2011. Dietary patterns of Pennsylvania coyotes during winter. Keystone Journal of Undergraduate Research 1:1318.

Stratman, M. R., and M. R. Pelton. 1997. Food habits of coyotes in northwestern Florida. Proceedings of the Annual Conference of Southeastern Association of Fish and Wildlife Agencies 51:269-275. 
Taylor, R. W., C. L. Counts III, and S. B. Mills. 1976. Occurrence and distribution of the coyote (Canis latrans) in West Virginia. Proceedings of the West Virginia Academy of Science 48:73-77.

Teerink, B. J. 1991. Hair of West-European mammals. Cambridge University Press, Cambridge, United Kingdom.

Thornton, D. H., M. E. Sunquist, and M. B. Main. 2004. Ecological separation within newly sympatric populations of coyotes and bobcats in south-central Florida. Journal of Mammalogy 85:973-982.

Thurber, J. M., and R. O. Peterson. 1991. Changes in body size associated with range expansion in the coyote (Canis latrans). Journal of Mammalogy 72:750-755.

Till, J. A., and F. F. Knowlton. 1983. Efficacy of denning in alleviating coyote depredations upon domestic sheep. Journal of Wildlife Management 47:1018-1025.

Tomsa, T. N., and J. E. Forbes. 1989. Coyote depredation control in New York - an integrated approach. Fourth Eastern Wildlife Damage Control Conference, 25-28 September 1989, Madison, Wisconsin, USA.

Toweill, D. E., and R. G. Anthony. 1988. Coyote foods in a coniferous forest in Oregon. The Journal of Wildlife Management 52:507-512.

Tremblay, J., M. Crete, and J. Huot. 1998. Summer foraging behavior of eastern coyotes in rural versus forest landscape: A possible mechanism of source-sink dynamics. Ecoscience 5:172-182.

Turner, M. M., A. P. Rockhill, C. S. Deperno, J. A. Jenks, R. W. Klaver, A. R. Jarding, T. W. Grovenburg, and K. H. Pollock. 2011. Evaluating the effect of predators on white-tailed deer: Movement and diet of coyotes. The Journal of Wildlife Management 75:905-912. 
USDA. 2007. Sheep and lamb predator death loss in the United States, 2004.

USDA-APHIS-VS-CEAH, National Animal Health Monitoring System, Fort Collins, CO, USA.

Van Dijk, J., K. Hauge, A. Landa, R. Andersen, and R. May. 2007. Evaluating scat analysis methods to assess wolverine Gulo gulo diet. Wildlife Biology 13:62-67.

VanGlider, C. L. 2008. Coyote and bobcat food habits and the effects of an intensive predator removal on white-tailed deer recruitment in Northeastern Alabama. Thesis, The University of Georgia, Athens, USA.

Vreeland, J. K., D. R. Diefenbach, B. D. Wallingford. 2004. Survival rates, mortality causes, and habitats of Pennsylvania white-tailed deer fawns. Wildlife Society Bulletin 32:542553.

Wagner, K. K., and M. R. Conover. 1999. Effect of preventive coyote hunting on sheep losses to coyote predation. Journal of Wildlife Management 63:606-612.

Wagner, G. D., and E. P. Hill. 1994. Evaluation of Southeastern coyote diets during the wild turkey reproductive season. Proceedings of the Southeastern Association of Fish and Wildlife Agencies 48:173-181.

Way, J. G., and J. Horton. 2004. Coyote kills harp seal. Canid News 7:1-4.

Weeks, J. L., M. C. Shieldcastle, and G. M. Tori. 1990. Coyotes (Canis latrans) in Ohio. Ohio Journal of Science 90:142-145.

Whittaker, D. G., and F. G. Lindzey. 1999. Effect of coyote predation on early fawn survival in sympatric deer species. Wildlife Society Bulletin 27:256-262. 
Wildlife Services. 2011. West Virginia integrated predation management program: 2011 annual report. United States Department of Agriculture, Animal and Plant Health Inspection Service, Wildlife Services, Elkins, West Virginia, USA.

Windberg, L. A., F. F. Knowlton, S. M. Ebbert, and B. T. Kelly. 1997. Aspects of coyote predation on angora goats. Journal of Range Management 50:226-230.

Witmer, G. W., M. J. Pipas, and A. Hayden. 1995. Some observations on coyote food habits in Pennsylvania. Journal of the Pennsylvania Academy of Science 69:77-80.

Wooding, J. B., E. P. Hill, and P. W. Sumner. 1984. Coyote food habits in Mississippi and Alabama. Proceedings of the Annual Conference of Southeastern Association of Fish and Wildlife Agencies 38:182-188.

Wykle, J. 1999. The status of the coyote, Canis latrans, in West Virginia. Thesis, Marshall University, Huntington, West Virginia, USA.

Young, J. K., W. F. Andelt, P. A. Terletzky, and J. A. Shivik. 2006. A comparison of coyote ecology after 25 years: 1978 versus 2003. Canadian Journal of Zoology 84:537-582. 


\section{CHAPTER 2}

\section{Coyote Diets in West Virginia}

(Formatted in the style of Journal of Wildlife Management) 


\section{CHAPTER 2}

\section{COYOTE DIETS IN WEST VIRGINIA}

April 2012

Geriann Albers

West Virginia University

322 Percival Hall

Morgantown, WV 26506

618/540-8556; Fax: 304/293-2441

galbers@mix.wvu.edu

RH: Albers et al. Coyote Diets in West Virginia

\section{Coyote Diets in West Virginia}

GERIANN ALBERS, Division of Forestry and Natural Resources, West Virginia University, Morgantown, WV 26506, USA

JOHN W. EDWARDS, Division of Forestry and Natural Resources, West Virginia University, Morgantown, WV 26506, USA

RICHARD E. ROGERS, West Virginia Division of Natural Resources, Romney, WV 26757 , USA

LAUREN L. MASTRO, USDA AHPIS Wildlife Services, National Wildlife Research Center, Elkins, $\quad$ WV 26241, USA

ABSTRACT The first record of a coyote (Canis latrans) in West Virginia dates to 1950, with sightings increasing in the 1970s and coyotes becoming a common occurrence statewide by the 1990s. Few studies have investigated the coyote's ecology or natural history in West Virginia. Understanding the role of coyotes in predator-prey relations and influences on game populations such as white-tailed deer (Odocoileus virginianus) is important baseline information in this recently colonized area. Our objective was to determine the diets of coyotes in West Virginia 
and compare them among seasons and regions and between ages and sex. In cooperation with West Virginia Division of Natural Resources, USDA APHIS Wildlife Services, and hunters and trappers, we collected coyote scats $(n=693)$ and stomach $(n=276)$ samples throughout West Virginia during November 2009-June 2011. We found white-tailed deer to be the most frequently (59.5\%) occurring item in samples followed by plant material (e.g., leaves, twigs, grass; 39.7\%), small mammals (e.g. mice, voles, woodrats [Neotoma spp] 19.3\%), fruits and seeds (e.g., fleshy fruit, seeds, acorns;16.1\%), and sciurids (11.4\%) such as squirrels (Sciurus spp. and Tamiasciurus hudsonicus) and chipmunks (Tamias striatus). White-tailed deer also represented the highest mean percent volume (44.9\%) in coyote diets, followed by small mammals (11.8\%), squirrels and chipmunks (8.2\%), fruits and seeds $(7.1 \%)$, and plant material (7.1\%). White-tailed deer occurred in coyote diets most frequently during January-April with a declining trend in May-December; squirrels and chipmunks and fruit and seeds occurrence showed the reverse trend. We found male coyotes consumed livestock more frequently than females, and that juveniles were less likely to consume fruits and seeds and more likely to have white-tailed deer present in stomachs than adults. Regional differences suggested that in areas with lower white-tailed deer density coyotes were consuming alternate items. Our findings suggest that coyotes in West Virginia do not rely heavily on anthropogenic sources of food. KEY WORDS Canis latrans, coyote, diet, livestock, Odocoileus virginianus, West Virginia, white-tailed deer

While many carnivores in North America have experienced range declines over the past few decades, coyotes have actually expanded their range (Laliberte and Rippe 2004) to include all of the contiguous United States and parts of Canada and Central America (Moore and Parker 1992). Historically a western plains species, coyotes were reported in Ohio as early as 1919 
(Weeks et al. 1990). A survey of Ohio conservation officers conducted in 1979 reported coyotes in 46 of 88 counties (Weeks et al. 1990). Coyotes were first documented in Pennsylvania in the 1940s (Hilton 1978, Hayden 2003), in northern Virginia near the eastern border with West Virginia in the mid-1960s (Carpenter 1971) and in Tucker County, West Virginia in 1950 (Taylor et al. 1976). Taylor et al. (1976) conducted a survey of West Virginia Division of Natural Resources (WVDNR) Conservation Officers in the mid 1970's to determine the occurrence of coyotes in the state after a male coyote was killed in Wayne County in early 1975. This survey resulted in 4 confirmed coyotes killed in the state, several unconfirmed reports, and 2 known imports of coyotes from Kansas (Taylor et al. 1976). Wykle (1999) conducted a survey of WVDNR personnel, farmers, hunters, trappers, and taxidermists in West Virginia and reported an increase in the number of coyote sightings in the mid-1990s, implying that populations were well established in most of the state by that time.

Coyotes have begun to partially fill ecological niches vacated by extirpated wolves (Canis spp.) and mountain lions (Puma concolor; Moore and Parker 1992). Coyotes have become the dominant large predator in many parts of their expanded range, including urban areas (Gompper 2002, Gehrt and Riley 2010). Coyotes can affect ecological communities directly through predation and competition with other carnivores, making their impact a potentially substantial one that must be understood for effective management of all wildlife species (BollinBooth 2007). Identifying and quantifying items in coyote diets is important to understanding their ecological role in newly exploited environs.

In the eastern United States, coyote diets are highly variable and include small mammals, fruits, insects, white-tailed deer (Odocoileus virginianus; hereafter deer), livestock and poultry (Gipson 1974, Wooding et al. 1984, Crossett and Elliott 1991, Hoerath and Causey 1991, Owens 
2006). Often certain prey items are more important regionally than others. Fruit, for example is frequently an important food item in the Southeast (Gabor 1993, Stratman and Pelton 1997, Grigione et al. 2011), whereas in the Northeast snowshoe hare (Lepus americanus) often dominates coyote diets (Lapierre 1985, Moore and Millar 1986, Parker 1986).

Food studies of coyotes in West Virginia are extremely limited. A single stomach from a road-killed male in Wayne County was found to contain persimmon (Diospyros virginiana) seeds (Taylor et al. 1976) and Wykle (1999) analyzed 24 stomachs from winter-killed coyotes and reported mostly deer and plant material in stomach samples.

Our objective was to determine the seasonal diets of coyotes in West Virginia. Moreover, we examined differences in diet between sex and age class, and among regions within the state. As coyotes are generalists in other portions of their range, we predicted coyote diets in West Virginia would be diverse and reflect the availability of native species and anthropogenic food sources.

\section{METHODS}

\section{Study Area}

We collected samples from 6 recognized ecological regions of West Virginia (Uhlig and Wilson 1952; Figure 1). Region 1 represents the Eastern Panhandle (Lithosol and shallow soils, 153 day average growing season, 52-54 degree average annual temperature, 30-40 inches average annual precipitation, red oak (Quercus rubra) and hard pine-oak predominant forest cover type), Region 2 the Mountains Region (Podzol soils, 143 day average growing season, 4852 degree average annual temperature, 40-60 inches average annual precipitation, northern hardwoods and red oak predominant forest cover type), Region 3 the Southern Region (Podzols and lithosols soils, 173 day average growing season, 52-56 degree average annual temperature, 
40-60 inches average annual precipitation, red oak and cove hardwoods predominant forest cover type), Region 4 the Central Region (Podzol soils, 155 day average growing season, 48-54 degree average annual temperature, 40-50 inches average annual precipitation, red oak and cove hardwoods predominant forest cover type, Region 5 the Northwestern Region (Lithosol and shallow soils, 165 day average growing season, 52-56 degree average annual temperature, 40-50 inches average annual precipitation, red oak predominant forest cover type), and Region 6 the Western Region (Lithosol and shallow soils, 171 day average growing season, 52-56 degree average annual temperature, 40-50 inches average annual precipitation, red oak and cove hardwoods predominant forest cover type). Our counties of focus for scat collection represented 3 of those regions: Southern Region (Raleigh County), Central Region (Lewis County) and Mountains Region (Pocahontas County; Figure 1). We collected scat in regions that had high participation of farms in USDA APHIS Wildlife Service's Intergrated Predation Management Program in order to supplement stomach collection in these regions to aid in addressing questions regarding livestock consumption by coyotes in West Virginia.

\section{Data Collection and Processing}

In cooperation with the West Virginia Division of Natural Resources (WVDNR), USDA APHIS Wildlife Services (WS), the West Virginia Trappers Association, and private citizens we collected coyote samples from November 2009 until June 2011 (Figure 2). Samples included: stomachs from coyotes trapped by fur trappers and shot by hunters, scat collected from select properties, and animals taken by WS as part of the Integrated Livestock Protection Program.

Stomachs. - We asked fur trappers and hunters to donate the stomachs and heads of harvested coyotes. We provided guides on how to remove the stomach and asked them to freeze samples. WS provided the carcasses of coyotes from throughout the state taken as part of the 
Integrated Predation Management Program throughout the state. We asked all contributors to provide the sex of the coyote, and the date and location of harvest. We froze carcasses prior to processing, examined stomachs, and recorded all pertinent information recorded on tags affixed to coyotes provided by trappers, hunters, and Wildlife Service Specialists (e.g., sex, location collected, date trapped, collector's name). A lower canine tooth was removed from all skulls collected. To reduce costs, radiographs were taken of teeth and all animals that showed signs of root-tip closure (i.e. adults; Knowlton and Whittemore 2001) were sent to Matson's Lab (Milltown, MT) for cementum annuli aging (Matson 1981). We processed stomachs following Korschgen $(1969,1980)$. We thawed, rinsed through a mesh sieve, and dried stomach contents in a drying oven for approximately $24 \mathrm{hrs}$. We separated contents and identified bone, hair, plant material, insects, and feathers to the lowest taxonomic group possible. We compiled a reference collection of mammal fur, plant material and other potential food items. We compared hair collected from samples to both the reference collection and published guides by Spence (1963), Moore et al. (1974) and Teerink (1991), and compared feathers to a guide by Dove and Koch (2010). We determined volume using the point-frame method (Chamrad and Box 1964). Using a modification of Chamrad and Box (1964), a 5×5 grid was placed over the sample of stomach contents and the item present at each node was identified and recorded. The number of points at which each item occurred was recorded and multiplied by 4 to obtain a volume that summed to $100 \%$.

Scat.- Scat was collected by WVDNR on lands in counties (Lewis, Pocahontas, and Raleigh) representing 3 ecological regions (Appendix I). The Lewis County scat route on Stonewall Jackson Wildlife Management Area was primarily composed of mature oak-hickory (Quercus spp. and Carya spp.) forest with a hardwood understory and sparse herbaceous 
groundcover limited to the edges of the road. The Pocahontas County scat route on Monongahela National Forest had two segments. One segment traversed northern hardwood forests with no day-lighting of roads and sparse understory; the second segment also consisted of northern hardwoods, but with some day-lighting of roads and thick understory and herbaceous groundcover. The final scat route in Raleigh County located on private property covered a diversity of habitat types including mixed mature timber (e.g., Prunus spp. and Acer spp.), old strip-mine benches, early successional habitat (some along gas lines) with dense groundcover, and mature oak-hickory forest with a mountain laurel (Kalmia latifolia) understory. Although scat routes did not directly traverse farms, they were within coyote home range area to farmland.

Scat was collected along predetermined trails or roads and then frozen until processing. Scat collection took place during 3 seasons: (1) breeding (January-April), (2) pupping (MayAugust) and (3) dispersal (September-December). Sixteen (16) km of trail or road were sampled twice monthly in each county. Initially, all scats were cleared from the route so only fresh scats were collected. We processed scat following Korschgen $(1969,1980)$. We soaked scat overnight, then washed the scat through mesh sieves, and dried them in a drying oven for $>24$ hrs. We separated materials in samples and identified contents using the same procedure used for stomach contents. Volume was determined using the same point-frame method as described for stomach contents.

Spotlight Distance Surveys. - WVDNR staff conducted spotlight distance surveys for white-tailed deer in the 3 counties representing the 3 ecological regions where scat samples were collected (Appendix J). WVDNR personnel conducted surveys during August 30-September 15, 2011. Surveys began approximately 30 minutes after sunset and were conducted from a motor vehicle moving less than $20 \mathrm{~km} / \mathrm{hr}$. Perpendicular distance from the deer to the driven 
transect was calculated with a range finder, and age class and sex were determined when possible (Buckland et al. 2001, Langdon 2001). We estimated deer density using the program DISTANCE 3.5 (Research Unit for Wildlife Population Assessment, University of St. Andrews, Scotland). Route length was between $74.2-178.8 \mathrm{~km}$. To acquire the minimum acceptable number of observations required for statistical validity using DISTANCE 3.5 ( 40 observations; Burnham et al. 1980), an additional route was conducted in Raleigh County. Habitat throughout the routes was similar to that reported for scat collection routes.

Statistical Analysis._ W We used summary statistics (e.g., mean frequency, percentage) to report food item occurrence and volume in coyote diets, between scat and stomach samples, age class, and sex, as well as among seasons and regions. We calculated relative item occurrence by dividing the number of samples that contained an item by the number of samples [(number of items belonging to species $\mathrm{X}) /($ total number of items $) \times 100$, where the number of $\mathrm{X}$ items corresponds to the number of samples containing each item; Leopold and Krausman 1986, Corbett 1989]. Juveniles were defined as animals <1 year of age as determined by cementum annuli analysis. We combined scat and stomach samples for analyses as they have been shown to yield comparable results when analyzing diets (Anthony and Smith 1974). We conducted a 1way analysis of similarity (ANOSIM) (Clarke 1988, 1993) to test for differences in coyote diets among seasons and regions using the Bray-Curtis metric (Sørenson 1948, Bray and Curtis 1957). ANOSIM is a non-parametric ordination technique that uses rank dissimilarity matrices. In ANOSIM, the $R$ statistic computed is the difference between the mean ranks of the groups; an $R$ closer to 1 indicates similarity, while an $R$ closer to 0 indicates random grouping. All statistics were completed using $\mathrm{R}_{\odot}$ (The R Foundation for Statistical Computing, Vienna, Austria). 
We used Kruskal-Wallis and Wilcoxon Pairwise comparisons to test for differences in individual diet items between sex and age class and among seasons and regions. For age and sex comparisons, only stomach samples were used as we did not have age and sex information for scat samples. For more detailed post-hoc comparisons, we examined deer, plant material (e.g., twigs, leaves, grass), fruits and seeds (e.g., fruit flesh, seeds, acorns), squirrels and chipmunks, small mammals (e.g., mice, voles, woodrats, jumping mice) and livestock (hereafter commonly occurring items or common items). These items were either $>10 \%$ occurrence, or in the case of livestock was considered an "item of interest" and occurred in $>6 \%$ of samples. We used Kruskal-Wallis and Wilcoxon pairwise tests to compare monthly differences of deer occurrence. December was excluded from monthly analysis due to small sample size. We compared percent occurrence of commonly occurring items in coyote scat and stomach samples between JanuaryJune 2010 and 2011. Full year comparisons were not possible because samples were not collected in the fall of 2011. We had insufficient sample size during 2009 to make any comparisons for that year. For white-tailed deer, we compared months of winter precipitation (January-March) and potential fawning months (April-June) between years. For all other comparisons, we compared January-June.

We conducted compositional analysis (Aebishcher et al. 1993) to determine if certain items were selected more frequently than others. Because availability of potential food items of coyotes statewide was unknown, we assumed equal availability (Dechmann et al. 2006). We grouped items in categories as follows: amphibians and reptiles, birds, deer, fruits and seeds, invertebrates, livestock, plant material, small mammals, and squirrels and chipmunks. We also included a 'trace' category to include items that did not fall into any of these categories. For instance, if a sample contained 5\% raccoon, it was counted as 5\% trace species. 


\section{RESULTS}

We processed 1,126 scat and stomach samples from 40 of 55 counties (73\%) in West Virginia (Figure 2; Appendix D). Of these samples, we used 969 (86\%) for analysis, including $n$ $=693$ scat samples and $n=276$ stomach samples (5 unknown age and sex, 20 unknown sex juveniles, 6 unknown sex adults, 67 juvenile males, 34 adult males, 9 unknown age males, 84 juvenile females, 35 adult females, 16 unknown age females). The remaining 157 samples were either empty stomachs or were eliminated due to data collection or transcription errors. We identified 61 diet items that we aggregated into categories (Appendix A). Some categories contained multiple species, such as "Sciurus" that included both fox squirrel (Sciurus niger) and gray squirrel (Sciurus carolinensis) and "Birds" that included any feathers or bird parts found. The average number of items in a single sample (not including empty stomachs was 2.2 items/sample (range 1-5 items).

Deer was the most frequently occurring item at $59.5 \%$, followed by plant material (39.7\%), small mammals (19.3\%), fruits and seeds (16.1\%), squirrels and chipmunks (11.4\%), insects (6.8\%), livestock (6.3\%), rabbit (Lepus americanus and Sylvilagus floridanus; 4.4\%), and birds (4.2\%; Appendix B). White-tailed deer also had the highest mean percent volume (44.9\%, $\mathrm{SE}=1.38 ;$ Appendix C), followed by small mammals $(11.8 \%, \mathrm{SE}=0.91)$, squirrels and chipmunks $(8.2 \%, \mathrm{SE}=0.80)$, fruits and seeds $(7.1 \%, \mathrm{SE}=0.67)$, and plant material $(7.1 \%, \mathrm{SE}=$ 0.47); mean volume of livestock in samples was $3.1 \%(\mathrm{SE}=0.48)$.

We found seasonal differences in coyote diets for deer $\left(\chi_{2}^{2}=105.26, P<0.001\right)$, squirrels and chipmunks $\left(\chi_{2}^{2}=21.84, P<0.001\right)$, livestock $\left(\chi_{2}^{2}=9.41, P=0.009\right)$, small mammals $\left(\chi_{2}{ }^{2}=\right.$ $7.08, P=0.029)$, and plant material $\left(\chi_{2}{ }^{2}=7.25, P=0.027\right.$; Table 1; Figure 3). Deer occurred more frequently in coyote scat and stomach samples during January-April whereas fruits and 
seeds and squirrels and chipmunks occurred more frequently during September-December (Table 1).

We found deer $\left(\chi_{1}^{2}=19.92, P<0.001\right)$ and livestock $\left(\chi_{1}^{2}=81.04, P<0.001\right)$ occurred more frequently in stomachs $(n=276)$ whereas plants $\left(\chi_{1}^{2}=4.83, P=0.028\right)$, fruits and seeds $\left(\chi_{1}^{2}=18.22, P<0.001\right)$ and squirrels and chipmunks $\left(\chi_{1}^{2}=16.51, P<0.001\right)$ occurred more frequently in scats $(n=693$; Table 2). Because stomach and scat samples were not paired (i.e., we did not have both stomach and scat from individual animals), and differences could reflect capture location, season, sex, trapping method, and differential digestion, we performed no further analyses to address this question.

Coyote consumption of deer was similar between years $\left(2010\right.$ and $2011 ; \chi_{1}^{2}=1.05, P=$ 0.310) and between pre-fawning (January-March; 78.4\% in 2010 and $72.6 \%$ in 2011) and fawning periods (April-June; 65.8\% in 2010 and $66.9 \%$ in $2011 ; \chi_{1}^{2}=5.54, P=0.140$ ). The occurrence of fruits and seeds $\left(\chi_{1}^{2}=6.21, P=0.013\right)$ and plant material $\left(\chi_{1}^{2}=4.68, P=0.031\right)$ in coyote scats and stomach samples was different between January-June $2010(n=246)$ and 2011 $(n=372$; Table 3$)$. The occurrence of small mammals $\left(\chi_{1}^{2}=0.83, P=0.362\right)$, livestock $\left(\chi_{1}^{2}=\right.$ $0.27, P=0.601)$, and squirrels and chipmunks $\left(\chi_{1}^{2}=0.01, P=0.901\right)$ were similar between years in coyote scat and stomach samples.

Male coyotes $(n=110)$ consumed livestock more frequently than female coyotes $(n=$ $135 ; \chi_{1}^{2}=4.27, P=0.039$; Table 4$)$. Consumption of other commonly occurring items was similar between sexes. We found differences in deer $\left(\chi_{1}^{2}=6.81, P=0.009\right)$ and fruits and seeds $\left(\chi_{1}^{2}=5.21, P=0.023\right)$ occurrence between age classes (juvenile $n=171$, adult $n=75$; Table 5); juveniles had more deer and less fruits and seeds in their stomachs than adults. 
We found no overall differences among region $(R=0.095)$ or season $(R=0.137)$ in coyote scat and stomach samples. When comparing among all 6 regions, percent occurrence of scat and stomach samples from the Southern Region (Region 3) was different from all other regions for both deer $\left(\chi_{5}{ }^{2}=178.37, P<0.001\right)$ and fruits and seeds $\left(\chi_{5}{ }^{2}=185.49, P<0.001\right.$; Table 6; Figure 4). The Southern Region scat and stomach samples also had higher squirrel and chipmunk occurrence compared to all regions except the Western Region (Region $6 ; \chi_{5}^{2}=82.81$, $P<0.001)$. Small mammals occurred in coyote scat and stomach samples less frequently in the Mountains Region (Region 2$)$ than the Southern Region $\left(\chi_{5}^{2}=12.89, P<0.024\right)$. We found livestock occurred less frequently in scat and stomach samples from the Southern Region than the Eastern Panhandle (Region 1), the Western Region, and the Northwestern Region (Region 5) and occurred more frequently in the Eastern Panhandle compared to the Mountains and the Central (Region 4) Regions $\left(\chi_{5}^{2}=45.14, P<0.001\right)$.

Deer was the most commonly selected item (i.e., highest ranked) in coyote scats and stomachs, followed by trace items, plant material, small mammals, fruits and seeds, squirrels and chipmunks, livestock, invertebrates, birds, and amphibians and reptiles (Table 7). Deer occurrence was consistently high during January-April (Figure 5), decreased during May-July, and reached a low during August-October. Occurrence began to increase again in November.

Distance Surveys. - We estimated Lewis County to have a deer density of 7.2 deer $/ \mathrm{km}^{2}$ $(\mathrm{CV}=0.21$; Table 8$)$. Pocahontas County deer density was estimated at $10.4 \mathrm{deer} / \mathrm{km}^{2}(\mathrm{CV}=$ 0.17). Raleigh County's combined deer density (including the additional route) was estimated at 4.8 deer $/ \mathrm{km}^{2}(\mathrm{CV}=0.50)$. This low density resulted in an extremely high coefficient of variation with corresponding low confidence in the final density estimate. As previously stated, the 
additional route added to meet minimum required observations for analysis had an estimated density of 8.2 deer $/ \mathrm{km}^{2}(\mathrm{CV}=0.18)$.

\section{DISCUSSION}

We found coyotes in West Virginia commonly consumed mammalian prey (e.g., deer, sciurid species, and small mammals). Fruit and seeds were also a common item as were plant materials such as leaves, grass, and twigs. In scats and stomachs, we found many late summer and fall fruiting species such as apples, pears, blackberry (Rubus fruticosus), raspberry (R. idaeus), wild grape (Vitus spp.), persimmon, and black cherry (Prunus serotina). A few acorns were found, but in very low amounts. The high occurrence of fruit in our samples is similar to what has been observed in other southeastern states (e.g., Wooding et al.1984, Blanton 1988, Witmer et al. 1995, Chamberlain and Leopold 1999, Grigione et al. 2011). Southeastern studies typically document high occurrence of persimmon (e.g., Gipson 1974, Michaelson 1975, Grogan 1996, Stratman and Pelton 1997), whereas our occurrence of persimmon was low (1.0\%), and our most commonly occurring fruit item was black cherry (7.6\%). As expected, black cherry and persimmon occurrence was highest in the fall months (28.4\% and $4.5 \%$, respectively). The lower occurrence of persimmon in our samples relative to reports from southeastern states may be because West Virginia is at the northern limits of the persimmon range. Persimmon trees are found in only 38 of 55 counties (69\%) in West Virginia (Harmon et al. 2006).

Plant material in stomach and scat samples had high occurrence $(39.7 \%)$ but low volume (7.1\%), which suggests that plant material was less important as a food item. Although canids are known to eat grass (Bjone et al. 2007, Sueda et al. 2008), most plant material in coyote diets is likely due to coyote feeding habits (e.g., a coyote picks up a few blades of grass when 
consuming a small mammal) or sample collection methods (e.g., a few leaves are combined with a scat sample).

We found a low occurrence of lagomorphs, including both eastern cottontail and snowshoe hare, in coyote scat and stomach samples (4.4\%). This is in contrast to western (Korschgen 1957, Best et al. 1981, MacCracken and Uresh 1984, Toweill and Anthony 1988, Huebschman et al. 1997) and southern (Michaelson 1975, Hernández et al. 1994) studies where cottontail rabbits (Sylvilagus spp.) are often a dominant item and northern studies where snowshoe hare is commonly consumed (Niebauer 1974, Lapierre 1985, Parker 1986, Dibello et al. 1990, Dumond et al. 2001). We found squirrel species to occur more frequently than rabbits. This was most evident in the Southern Region where squirrels comprised $24 \%$ of samples, whereas rabbits composed only 3\%. Populations of rabbits are not currently monitored in West Virginia; however, the annual West Virginia Bowhunter Survey (Ryan et al. 2010) which began in 1995 has reported a decreasing trend in rabbit numbers in the state with an all-time low in recorded sightings in 2010 (statewide 1.05 rabbits/100 hrs). The survey report suggests aging forests and loss of habitat around farms due to changing farming practices may be influencing the populations of rabbits in the state. Ryan et al. (2010) also documented an increase in squirrel sightings (statewide 76.66 animals/100 hrs in 2010), especially in years following large mast crops. Snowshoe hare, although present in the state are limited in range to the mountainous eastern section of West Virginia and not commonly available to coyotes state-wide.

We found birds in $4.2 \%$ of stomach and scat samples, typically in the form of feathers. Among the identified feathers were songbirds, domestic poultry, and game birds, particularly gallinaceous birds. We did not have sufficient sample size to assess changes seasonally, but their low occurrence suggests coyotes do not heavily prey upon game birds (e.g., wild turkey 
[Meleagris gallopavo] and ruffed grouse [Bonasa umbellus]) as also documented by Wagner and Hill (1994). The presence of songbird feathers in samples is indicative of the coyote's opportunistic foraging behavior.

Livestock occurrence in coyote scat and stomach samples was also lower than other natural items. The majority of livestock found in samples was cattle $(61.0 \%$ of livestock occurrence), followed by sheep (34.0\%). We also found traces of goat and horse, but they occurred in $<1 \%$ of scat and stomach samples. As with other animal prey items it was not possible for us to determine if livestock present in samples was the result of predation or scavenging.

We found scant evidence of domestic pets in scat and stomach samples. Only 3 samples contained domestic cat hair. None of our samples contained domestic dog hair. Coyotes will prey upon cats (Grubbs and Krausman 2009); however cat occurrence in our samples was low. Additionally, we found some anthropogenic materials, but in low amounts (1.7\%). Some of these materials found in stomach samples were likely the result of trapping (e.g., pieces of rubber, polyfill-like material). Other materials were likely from coyote scavenging human refuse or other materials near human development. Notable materials included fast food napkins and wrappers, sauce packets, a chip bag, and pieces of commercially produced crab. Urban studies of coyotes have documented a higher occurrence of trash in diets (Fedriani et al. 2001, Grigione et al. 2011) than rural studies. Although our samples tended to come from animals in more rural areas, the opportunistic nature of coyotes would suggest that they will consume anthropogenic food when available. Our study supports results reported by Lee (1986) and Morey et al. (2007) that the occurrence of human refuse and other anthropogenic sources of food are often lower than would be expected based on the opportunistic feeding habits of the coyote. 
Coyotes are known to consume invertebrates when available (Gipson 1974, Blanton 1988, Stratman and Pelton 1997, Owens 2006, Grigione et al. 2011). We found invertebrates in $6.8 \%$ of our samples, which included coleopterans (3.4\%), hymenopterans $(0.1 \%)$, and orthopterans (3.2\%), as well as trace amounts of worms and other invertebrates. We had many items that we considered "trace" items, occurring in $<1 \%$ occurrence in samples. These items included amphibians and reptiles, beaver (Castor canadensis), black bear (Ursus americanus), crayfish, gray fox (Urocyon cinereoargenteus), muskrat (Ondatra zibethicus), moles, opossum (Didelphis virginiana), raccoon (Procyon lotor), red fox (Vulpes vulpes), skunk species (Mephitis mephitis and Spilogale putorius), and weasel species (Mustela spp.). Also, 1.1\% of samples were "unknown" and could not be identified. Items that were not commonly occurring but occurred in greater than $1 \%$ in samples included groundhog (Marmota monax; $2.6 \%$ ), coyote (1.9\%), and unidentifiable bone (2.6\%) and materials that were likely incidental such as rocks (12.4\%) and organic material (i.e., dirt and sand; 6.5\%). The black bear may have been scavenged, though it is possible a coyote killed or pulled a cub out of a den. The amphibian and reptile remains found included a frog leg, turtle scutes, and shed snake skin. Amphibian species are difficult to identify in samples because there are no hair, feathers, or scales to aid in identification, so these species and other "soft" foods (e.g., muscle tissue, fruit flesh) are often underestimated in samples (Harman and Stains 1979, Selås et al. 2007). The presence of coyote in samples could be a result of grooming, attempts to escape from traps once caught, or even cannibalism in extreme cases.

Coyotes are opportunistic omnivores that consume a highly variable diet throughout the year. Seasonally, deer was the most commonly occurring item from January-August. We found fruit and seed occurrence to be highest during September-December, which is likely attributable 
to fall ripening species like domestic apples, pears, wild grapes, persimmon, and black cherry. We also found that during September-December squirrels and chipmunks were consumed more frequently than most other items. September-December is when juvenile squirrels are becoming independent making them more vulnerable to predation (Koprowski 1994a, Koprowski 1994b, Edwards et al. 2003). Coyotes may focus on squirrels when they are more active collecting and caching acorns in the fall months. It is also possible, like with any fall hunted species, hunter killed but not retrieved animals may have contributed to presence of squirrels in coyote scat and stomach samples during the fall months.

Higher occurrence of fruit in coyote scats and stomachs during January-March 2011 may be attributable to high mast index of species such as black cherry (up 58\%), apple (up 5\%), crabapple (Malus spp.; up 8\%), and grape (up 6\%) during the fall of 2010 (Peters et al. 2011). Higher occurrence of squirrels in samples during January-June 2011 may also be linked to the high mast numbers in 2010 as increased availability of soft mast likely resulted in higher survival rates among squirrels. In addition to soft mast species, hard mast such as oaks (Quercus spp.) were $60-115 \%$ higher than the index average, as were hickory nuts (Carya spp.; 16\%). Sassafras (Sassafras albidum; 3\%), and hawthorn (Crataegus spp.; 18\%) also were higher than the index average (Peters et al. 2011). High seed crops have been shown to increase squirrel survival, especially of juveniles (Nixon et al. 1975, Koprowski 1994a, Koprowski 1994b). The good mast crop of 2010 may have increased squirrel abundance in early 2011 and resulted in a higher occurrence of squirrels in samples during January-June 2011. Relatedly, Bergeron et al. (2011) found chipmunks can anticipate high mast years and will breed during a summer as a result of anticipated pulsed resources. If chipmunks anticipated high 2010 mast with a second breeding 
cycle in summer, this could also have increased occurrence of chipmunks in samples during the fall of 2010 .

Our finding that male coyote stomach samples had a higher occurrence of livestock than female stomach samples supports the findings of Connolly et al. (1976), Windberg et al. (1997), and Blejwas et al. (2006) that males are more likely to prey upon livestock than females. With the exception of livestock, male and female coyotes were both equally opportunistic in diet item selection. Juvenile coyotes had deer in their stomachs more frequently than adults, which is consistent with Harrison and Harrison (1984). Juveniles also had less fruit and seeds in their stomachs than adults. As fruit was most common in scat and stomach samples in fall, this could suggest that younger animals may be selecting more protein-rich items to enable them to reach adult size, disperse, and or survive the winter months. Alternatively, and possibly more likely, juveniles may be consuming more prey items such as deer while still with their family groups pre-dispersal. Fruit consumption would be primarily done individually, while hunting for prey items would be done in groups (Gese et al. 1988, Gese 2004), so it is possible while still with their family group they consume more meat-based items as hunting larger prey is easier in groups.

Deer density in the Southern Region was far lower than in other regions $\left(4.77 / \mathrm{km}^{2}\right.$ compared to $7.24 / \mathrm{km}^{2}$ and $10.44 / \mathrm{km}^{2}$ ) of the state, which is likely why we found less deer in both sample types from that region. Our results support that coyotes are opportunistic and switch prey readily. However, our results contradict the findings of Schrecengost et al. (2008) that who reported high deer occurrence in coyote diets despite low deer density in South Carolina. More studies are needed in the mid-Atlantic region on deer-coyote interactions, but our results do not appear to support hypotheses from the southeastern United States that coyotes affect deer 
recruitment (Schrecengost et al. 2008, VanGlider 2008, Kilgo et al. 2010, Jackson 2011) as we did not see a peak of fawn occurrence in coyote scat and stomach samples during fawning months. Although fawn survival has not been studied in West Virginia, Vreeland et al. (2004) found fawn survival to be $72.4 \%$, in Pennsylvania and coyotes accounted for $36.7 \%(n=49)$ of predation mortality. Vreeland et al. (2004) suggested that the population of deer in Pennsylvania was still increasing and mortality of fawns was not limiting the population.

Coyote predation of deer is an issue of concern for hunters and wildlife managers, so our finding that deer was the most commonly occurring item in scat and stomach samples is of note. We had an unusually high amount of snow in West Virginia during the coyote breeding season of 2010, especially in February of 2010 (NOAA 2011). If coyote predation of deer increases with increasing snow depth as suggested by Lavigne (1992), Patterson et al. (1998), and Patterson and Messier (2000), the large amount of snow may have resulted in a higher occurrence of deer in scat and stomach samples during January-April of 2010. Although occurrence of deer in scat and stomach samples was slightly higher during this period, it was not a significant increase. Deer occurrence in scat and stomach samples also did not peak during fawning season as documented by Schrecengost et al. (2008). Our monthly analysis showed no peak in deer consumption by coyotes during fawning as might be expected (Figure 5). There was a $17 \%$ decrease in deer occurrence in coyote diets from April to May, though occurrence during May and June, the peak of fawning, were similar. While this may be due to limited consumption of fawns by coyotes or due to a poor fawn recruitment year, occurrence of deer in samples was lower during fawning season than during January-April. This is in contrast to studies that document high occurrence of fawn hair in coyote diets during fawning months (e.g. Blanton and Hill 1989, Brundige 1993, Schrecengost et al. 2008) and many fawn mortality 
studies that have documented coyote predation of fawns (Whittaker and Lindzey 1999, Vreeland et al. 2004, Rohm et al. 2007, Saalfeld and Ditchkoff 2007, Piccolo et al. 2010).

We can make no assertions as to whether deer in samples were scavenged or preyed upon, but several possible reasons for increased deer occurrence in diets during the winter months exist. In Minnesota, DelGiudice et al. (2002) found white-tailed deer death from natural causes (e.g., starvation, wolf predation, bobcat predation) was directly related to snow depth. They found low mean marrow-fat contents in long bones from deer killed during the severest winter of their study, suggesting deer may have been suffering from malnutrition. Also, the crude mortality rate increased from 0.182 during years with a low winter-severity index, to 0.458 in the year with the highest winter-severity index, which the authors suggested was likely due to a combination of poor nutrition and higher predation rates due to snow depth (DelGiudice et al. 2002). Other studies have documented predation of deer may be easier for coyotes when deep snow events impede deer movements (Lavigne 1992, Patterson et al. 1998, Patterson and Messier 2000). Also, carcasses may be scavenged more during January-March because of starvation events and during November due to increased roadkill (Crum 2010) or offal and the presence of unrecovered deer during hunting seasons. Our observation that deer occurrence did not increase during fawning, combined with the overall low recording of what appeared to be fawn hair in samples, suggests that coyotes in West Virginia may not be selecting for fawns as heavily as reported in some areas such as the southeast (Schrecengost et al. 2008, VanGlider 2008, Kilgo et al. 2010, Jackson 2011).

\section{MANAGEMENT IMPLICATIONS}

The mid-Atlantic region is one of the last areas of the United States to be colonized by coyotes (Parker 1995), and their ecology in this region requires further study (Mastro 2011). 
Coyotes are adaptable and opportunistic, so understanding their ecology on a local and regional scale is important for management decisions. Diet studies provide baseline information needed to begin to understand the natural history of a species. Additional research is needed on the ecology of coyotes in West Virginia, especially on home ranges, habitat use, and further exploration of coyote-deer interactions. Information regarding reproduction is also needed to understand the population structure and recruitment rates of coyotes in West Virginia.

Our findings document that coyote diets in West Virginia vary seasonally and, to a lesser degree regionally. Our results suggest that juvenile coyotes may consume deer more frequently than adults as result of higher predation of larger animals while with their family group predispersal. Coyotes in West Virginia did not have a high occurrence of anthropogenic materials, domestic pets, or livestock in their diets suggesting they do not rely heavily on anthropogenic sources of food. We found that in areas with low deer density, coyotes consume other items more frequently.

\section{ACKNOWLEDGMENTS}

We would like to acknowledge our funding sources, West Virginia University Division of Forestry and Natural Resources, the West Virginia Division of Natural Resources, USDA APHIS Wildlife Services, and The Berryman Institute. Thank you to Wildlife Services staff, West Virginia Division of Natural Resources personnel, hunters, trappers, and the West Virginia Trappers Association for assistance in sample collection. Thank you to A. N. Tri and J. Q.

Burkhardt for statistical advice, and M. D. Jones, A. N. Tri, and J. L. Berl for critical review. Thanks to all volunteers, interns, and technicians who aided in sample processing, especially L.C. Moon. 


\section{LITERATURE CITED}

Aebischer, N. J., P. A. Robertson, R. E. Kenward. 1993. Compositional analysis of habitat use from animal radio-tracking data. Ecology 74:1313-1325.

Anthony, R. G., and N. S. Smith. 1974. Comparison of rumen and fecal analysis to describe deer diets. Journal of Wildlife Management 38:535-540.

Bergeron, P., D. Reale, M. M. Humphries, and D. Garant. 2011. Anticipation and tracking of pulsed resources drive population dynamics in eastern chipmunks. Ecology 92:20272034.

Best, T. L., B. Hoditschek, and H. H. Thomas. 1981. Foods of coyotes (Canis latrans) in Oklahoma. The Southwestern Naturalist 26:67-69.

Bjone, S. J., W. Y. Brown, and I. R. Price. 2007. Grass eating patterns in the domestic dog, Canis familiaris. Recent Advances in Animal Nutrition in Australia 16:45-49.

Blanton, K. 1988. Summer diet of coyotes in the southeast, and the response of coyotes to siren surveys. Thesis, Mississippi State University, Starkville, USA.

Blanton, K. M., and E. P. Hill. 1989. Coyote use of white-tailed deer fawns in relation to deer density. Proceedings of the Annual Conference of Southeastern Association of Fish and Wildlife Agencies 43:470-478.

Blejwas, K. M., C. L. Williams, G. T. Shin, D. R. McCullough, and M. M. Jaeger. 2006. DNA evidence convicts breeding male coyotes of killing sheep. Journal of Wildlife Management 70:1087-1093.

Bollin-Booth, H. A. 2007. Diet analysis of coyote (Canis latrans) in metropolitan park systems of northeast Ohio. Thesis, Cleveland State University, Ohio, USA. 
Bray, J. R., and J. T. Curtis. 1957. An ordination of the upland forest communities of southern Wisconsin. Ecological Monographs 27:326-349.

Brundige, G. C. 1993. Predation ecology of the eastern coyote, Canis latrans var., in the Adirondacks, New York. Disseratation, State University of New York College of Environmental Science and Forestry, Syracuse, USA.

Buckland, S. T., D. R. Anderson, K. P. Burnham, D. L. Borchers, J. L. Laake, and L. Thomas. 2001. Introduction to distance sampling: estimating abundance of biological populations. Oxford University Press, Oxford, United Kingdom.

Burnham, K. P., D. R. Anderson, and J. L. Laake. 1980. Estimation of density from line transect sampling of biological populations. Wildlife Monographs 72:1-202.

Carpenter, M. 1971. Some recent coyote records in Virginia. Virginia Wildlife 32:14-15.

Chamberlain, M. J., and B. D. Leopold. 1999. Dietary patterns of sympatric bobcats and coyotes in Central Mississippi. Proceedings of the Southeastern Association of Fish and Wildlife Agencies 53:204-219.

Chamrad, A. D., and T. W. Box. 1964. A point frame for sampling rumen contents. Journal of Wildlife Management 28:473-477.

Clarke, K. R. 1988. Detecting change in benthic community structure. Pages 131-142 in R. Oger (editor). Proceedings of invited papers, 14th Annual International Biometric Conference, 17-23 July 1988, Namour, Belgium.

Clarke, K. R. 1993. Non-parametric multivariate analyses of changes in community structure. Australian Journal of Ecology 18:117-143.

Connolly, G. E., R. M. Timm, W. E. Howard, and W. M. Longhurst. 1976. Sheep killing behavior of captive coyotes. Journal of Wildlife Management 40:400-407. 
Corbett, L. K. 1989. Assessing the diet of dingoes from feces: a comparison of 3 methods. Journal of Wildlife Management 53:343-346.

Crossett, R. L., and C. L. Elliott. 1991. Winter food habits of red foxes and coyotes in central Kentucky. Proceedings of the Annual Conference of Southeastern Association of Fish and Wildlife Agencies 45:97-103.

Crum, J. M. 2010. Nonseasonal mortality white-tailed deer. West Virginia Division of Natural Resources. http://wvdnr.gov/Hunting/BGB2003DeerDeerNSeasMortal.shtm. Accessed 8 April 2012.

Dechmann, D. K. N., K. Safi, and M. J. Vonhof. 2006. Matching morphology and diet in the disc-winged bat Thyroptera Tricolor (Chiroptera). Journal of Mammalogy 87:10131019.

DelGiudice, G. D., M. R. Riggs, P. Joly, and W. Pan. 2002. Winter severity, survival, and cause-specific mortality of female white-tailed deer in north-central Minnesota. Journal of Wildlife Management 66:698-717.

Dibello, F. J., S. M. Arthur, and W. B. Krohn. 1990. Food habits of sympatric coyotes, Canis latrans, red foxes, Vulpes vulpes, and bobcats, Lynx rufus, in Maine. Canadian Field Naturalist 104:403-408.

Dove, C. J., and S. L Koch. 2010. Microscopy of feathers: A practical guide for forensic feather identification. Journal of the American Society of Trace Evidence Examiners 1:15-61.

Dumond, M., M. Villard, E. Tremblay. 2001. Does coyote diet vary seasonally between a protected and an unprotected forest landscape? Ecoscience 8:301-310.

Edwards, J. W., M. Ford, and D. Guynn. 2003. Fox and Gray Squirrels. Pages 248-267 in G. A. Feldhammer, B. C. Thompson, and J. A. Chapman editors. Wild mammals of North 
America: biology, management, and conservation. The Johns Hopkins University Press, Baltimore, Maryland, USA.

Fedriani, J. M., T. K. Fuller, and R. M. Sauvajot. 2001. Does availability of anthropogenic food enhance densities of omnivorous mammals? An example with coyotes in southern California. Ecography 24:325-331.

Gabor, T. M. 1993. An assessment of the feeding ecology of coyotes in Western Tennessee. Thesis, University of Memphis, Tennessee, USA.

Gehrt, S. D., and S. P. D. Riley. 2010. Coyotes (Canis latrans). Pages 79-95 in S. D. Gehrt, S. P. D. Riley, and B. L Cypher editors. Urban carnivores. The Johns Hopkins University Press, Baltimore, Maryland, USA.

Gese, E. M. 2004. Coyotes in Yellowstone National Park: the influence of dominance on foraging, territoriality, and fitness. Pages 271-284 in W. MacDonald and C. SilleroZubiri (editors). The Biology and Conservation of Wild Canids. Oxford University Press, Oxford, United Kingdom.

Gese, E. M., O. J. Rongstad, and W. R. Mytton. 1988. Relationship between coyote group size and diet in southeastern Colorado. Journal of Wildlife Management 52:647-653.

Gipson, P. S. 1974. Food habits of coyotes in Arkansas. Journal of Wildlife Management $38: 848-853$.

Gompper, M. E. 2002. Top carnivores in the suburbs? Ecological and conservation issues raised by the colonization of north-eastern North America by coyotes. BioScience 52: 185-190.

Grigione, M. M., P. Burman, S. Clavio, S. J. Harper, D. Manning, R. J. Sarno. 2011. Diet of Florida coyotes in a protected wildlife and suburban habitat. Urban Ecosystems. 
Grogan, M. E. 1996. Feeding strategies of the coyote (Canis latrans) in western Tennessee. Thesis, University of Memphis, Tennessee, USA.

Grubbs, S. E., and P. R. Krausman. 2009. Observations of coyote-cat interactions. Journal of Wildlife Management 73:683-685.

Harman, D. M., and H. J. Stains. 1979. The raccoon (Procyon lotor) on St. Catherines Island, Georgia: Winter, spring and summer food habits. American Museum Novitates 2679:124.

Harmon, P. J., D. Ford-Werntz, W. Grafton, editors. 2006. Checklist and atlas of the vascular flora of West Virginia. West Virginia Division of Natural Resources, Wildlife Resources Section, Elkins, USA.

Harrison, D. J. and J. A. Harrison. 1984. Foods of adult Maine coyotes and their known-aged pups. Journal of Wildlife Management 48:922-926.

Hayden, A. 2003. Coyote: Wildlife Note 39. Pennsylvania Game Commission, Harrisburg, PA, USA.

Hernández, L., M. Delibes, F. Hiraldo. 1994. Role of reptiles and arthropods in the diet of coyotes in extreme desert areas of northern Mexico. Journal of Arid Environments 26:165-170.

Hill, E. P., P. W. Sumner, and J. B. Wooding. 1987. Human influences on range expansion of coyotes in the Southeast. Wildlife Society Bulletin 15:521-524.

Hilton, H. 1978. Systematics and ecology of the eastern coyote. Pages 209-228 in M. Bekoff, editor. Coyotes: biology, behavior, and management. The Blackburn Press, Caldwell, New Jersey. USA. 
Hoerath, J. D., and M. K. Causey. 1991. Seasonal diets of coyotes in western central Alabama. Proceedings of the Annual Conference of Southeastern Association of Fish and Wildlife Agencies 45:91-96.

Huebschman, J. J., S. E. Hygnstrom, and J. A. Gubanyi. 1997. Coyote food habits at DeSoto National Wildlife Refuge, Nebraska. The Prairie Naturalist 29:99-109.

Jackson, A. M. 2011. Survival estimates of white-tailed deer fawns at Fort Rucker, Alabama. Thesis, Auburn University, Alabama, USA.

Kilgo, J. C., H. S. Ray, C. Ruth, and K. V. Miller. 2010. Can coyotes affect deer populations in southeastern North America. Journal of Wildlife Management 74:929-933.

Knowlton, F. F., and S. L. Whittemore. 2001. Pulp cavity-tooth width ratios from known-age and wild-caught coyotes determined by radiography. Wildlife Society Bulletin 29:239_ 244.

Koprowski, J. L. 1994a. Sciurus niger. Mammalian Species 479:1-9.

Koprowski, J. L. 1994b. Sciurus carolinensis. Mammalian Species 480:1-9.

Korschgen, L. J. 1957. Food habits of the coyote in Missouri. The Journal of Wildlife Management 21:424-435.

Korschgen, L. J. 1969. Procedures for food habit analysis. Pages 233-250 in R.H. Giles, Jr., (editor). Wildlife Management Techniques. The Wildlife Society, Washington, D.C., USA.

Korschgen, L. J. 1980. Procedures for food habit analysis. Pages 113-127 in S. D. Schemnitz, (editor). Wildlife Management Techniques. The Wildlife Society, Washington, D.C., USA. 
Laliberte, A. S., and W. J. Ripple. 2004. Range contractions of North American carnivores and ungulates. BioScience 54:123-138.

Langdon, C. A. 2001. A comparison of white-tailed deer population estimation methods in West Virginia. Thesis, West Virginia University, Morgantown, USA.

Lapierre, L. E. 1985. Fall and winter food habits of the eastern coyote Canis latrans in southeastern New Brunswick. Proceedings of the Nova Scotian Institute of Science $35: 71-74$.

Lavigne, G. R. 1992. Sex/age composition and physical condition of deer killed by coyotes during winter in Maine. Pages 141-160 in Boer, A. (editor). Ecology and Management of the Eastern Coyote. Wildlife Research Unit, University of New Brunswick, Fredericton, Canada.

Lee, R. M. 1986. Food habits of the coyote, Canis latrans, in Tennessee. Thesis, Memphis State University, Tennessee, USA.

Leopold, B. D., and P. R. Krausman. 1986. Diets of 3 predators in Big Bend National Park, Texas. Journal of Wildlife Management 50:290-295.

MacCracken, J. G., and D. W. Uresh. 1984. Coyote foods in the Black Hills, South Dakota. Journal of Wildlife Management 48:1420-1423.

Mastro, L. L. 2011. Life history and ecology of coyotes in the Mid-Atlantic States: a summary of the scientific literature. Southeastern Naturalist 10:721-730.

Matson, G. M. 1981. Workbook for cementum analysis. Matson’s, Milltown, Montana, USA. Michaelson, K. A. 1975. Food habits of coyotes in northwest Louisiana. Thesis, Louisiana Tech University, Ruston, USA. 
Moore, T. D., C.E. Dugnolle, and L. E. Spence. 1974. Identification of the dorsal guard hairs of some mammals of Wyoming. Wyoming Game and Fish Department Bulletin No. 14. Cheyenne, Wyoming, USA.

Moore, G. C., and J. S. Millar. 1986. Food habits and average weights of a fall-winter sample of eastern coyotes, Canis latrans. Canadian Field Naturalist 100:105-106.

Moore, G. C., and G. R. Parker. 1992. Colonization by the eastern coyote (Canis latrans). Pages 23-37 in Boer, A. (editor). Ecology and Management of the Eastern Coyote. Wildlife Research Unit, University of New Brunswick, Fredericton, Canada.

Morey, P. S., E. M. Gese, and S. Gehrt. 2007. Spatial and temporal variation in the diet of coyotes in the Chicago metropolitan area. American Midland Naturalist 158:147-161.

National Agricultural Statistics Service [NASS]. 2011. Quick Stats: Cattle and Sheep Inventories. http://quickstats.nass.usda.gov/. Accessed 4 Jan 2012.

National Oceanic and Atmospheric Administration [NOAA]. 2010. National Climatic Data Center, State of the Climate: National Snow \& Ice for February. http://ncdc.noaa.gov/sotc/snow/2010/2. Accessed 5 Dec 2011.

Niebauer, T. J. 1974. Coyote food habits in northwestern Wisconsin. Thesis, University of Wisconsin, Madison, USA.

Nixon, C. M., M. W. McClain, and R. W. Donohoe. 1975. Effects of hunting and mast crops on a squirrel population. Journal of Wildlife Management 39:1-25.

Owens, K. M. 2006. Seasonal dietary composition of the eastern coyote (Canis latrans) on the Berry College campus in northwestern Georgia. Thesis, University of Tennessee, Chattanooga, USA. 
Parker, G. R. 1986. Food habits and average weights of a fall-winter sample of eastern coyotes, Canis latrans. Canadian Field Naturalist 100:74-77.

Parker, G. R. 1995. Eastern Coyote: The story of its success. Nimbus Publishing, Halifax, Nova Scotia, Canada.

Patterson, B. R., L. K. Benjamin, and F. Messier. 1998. Prey switching and feeding habits of eastern coyotes in relation to snowshoe hare and white-tailed deer densities. Canadian Journal of Zoology 76:1885-1897.

Patterson, B. R., and F. Messier. 2000. Factors influencing killing rates of white-tailed deer by coyotes in Eastern Canada. Journal of Wildlife Management 64:721-732.

Peters, M. L., W. K. Igo, C. W. Ryan, and R. L. Tucker. 2011. 2011 West Virginia mast survey and hunting outlook. West Virginia Division of Natural Resources Wildlife Resources Bulletin 11-4.

Piccolo, B. P., T. R. Van Deelen, K. Hollis-Etter, R. E. Warner, and C. Anchor. 2010. Behavior and survival of white-tailed deer neonates in two suburban forest preserves. Canadian Journal of Zoology 88:487-495.

Rohm, J. H., C. K. Nielsen, and A. Woolf. 2007. Survival of white-tailed deer fawns in Southern Illinois. Journal of Wildlife Management 71:851-860.

Ryan, C. W., C. D. Teets, R. L. Tucker, K. D. Krantz, and S. A. Warner. 2010. West Virginia bowhunter survey. Wildlife Resources Section Bulletin 11-03. Charleston, West Virginia, USA.

Saalfeld, S. T., and S. S. Ditchkoff. 2007. Survival of neonatal white-tailed deer in an exurban population. Journal of Wildlife Management 71:940-944. 
Schrecengost, J.D., J. C. Kilgo, D. Mallard, H. S. Ray, and K. V. Miller. 2008. Seasonal food habits of the coyote in the South Carolina coastal plain. Southeastern Naturalist 7:135144.

Selås, V., R. Tveiten, and O. M. Aanonsen. 2007. Diet of common buzzards (Buteo buteo) in southern Norway determined from prey remains and video recordings. Ornis Fennica 84:97-104.

Sørenson, T. J. 1948. A method of establishing groups of equal amplitude in plant society based on similarity of species content. Det Kongelige Danske Videnskabernes Selskab Biologiske Skrifter 5:1-34.

Spence, L. E. 1963. Study for identifying characteristics of mammal hair. Wyoming Game and Fish Commission Job Completion Report Project FW 3-R-10, Work Plan No. 10, Job No. 2W, Laramie, USA.

Stratman, M. R., and M. R. Pelton. 1997. Food habits of coyotes in northwestern Florida. Proceedings of the Annual Conference of Southeastern Association of Fish and Wildife Agencies 51:269-275.

Sueda, K. L. C., B. L. Hart, and K. D. Cliff. 2008. Characterisation of plant eating in dogs. Applied Animal Behaviour Science 11:120-132.

Taylor, R. W., C. L. Counts III, and S. B. Mills. 1976. Occurrence and distribution of the coyote (Canis latrans) in West Virginia. Proceedings of the West Virginia Academy of Science 48:73-77.

Teerink, B. J. 1991. Hair of West-European mammals. Cambridge University Press, Cambridge, United Kingdom. 
Toweill, D. E., and R. G. Anthony. 1988. Coyote foods in a coniferous forest in Oregon. The Journal of Wildlife Management 52:507-512.

Uhlig, H. G., and H. L Wilson. 1952. A method of evaluating an annual mast index. Journal of Wildlife Management 16:338-343.

VanGlider, C. L. 2008. Coyote and bobcat food habits and the effects of an intensive predator removal on white-tailed deer recruitment in Northeastern Alabama. Thesis, The University of Georgia, Athens, USA.

Vreeland, J. K., D. R. Diefenbach, and B. D. Wallingford. 2004. Survival rates, mortality causes, and habitats of Pennsylvania white-tailed deer fawns. Wildlife Society Bulletin 32:542-553.

Wagner, G. D., and E. P. Hill. 1994. Evaluation of Southeastern coyote diets during the wild turkey reproductive season. Proceedings of the Southeastern Association of Fish and Wildlife Agencies 48:173-181.

Weeks, J. L., M. C. Shieldcastle, and G. M. Tori. 1990. Coyotes (Canis latrans) in Ohio. Ohio Journal of Science 90:142-145.

Whittaker, D. G., and F. G. Lindzey. 1999. Effect of coyote predation on early fawn survival in sympatric deer species. Wildlife Society Bulletin 27:256-262.

Windberg, L. A., F. F. Knowlton, S. M. Ebbert, and B. T. Kelly. 1997. Aspects of coyote predation on angora goats. Journal of Range Management 50:226-230.

Witmer, G. W., M. J. Pipas, and A. Hayden. 1995. Some observations on coyote food habits in Pennsylvania. Journal of the Pennsylvania Academy of Science 69:77-80. 
Wooding, J. B., E. P. Hill, and P. W. Sumner. 1984. Coyote food habits in Mississippi and Alabama. Proceedings of the Annual Conference of Southeastern Association of Fish and Wildlife Agencies 38:182-188.

Wykle, J. 1999. The status of the coyote, Canis latrans, in West Virginia. Thesis, Marshall University, Huntington, West Virginia, USA. 
Table 1. Occurrence of common items in coyote stomach samples among seasons in West Virginia, November 2009-June 2011. Sample size is in parentheses.

\begin{tabular}{lccc}
\hline Item & $\begin{array}{c}\text { January-April } \\
\text { Season 1 } \\
(n=450)\end{array}$ & $\begin{array}{c}\text { May-August } \\
\text { Season 2 } \\
(n=273)\end{array}$ & $\begin{array}{c}\text { September-December } \\
\text { Season 3 } \\
(n=222)\end{array}$ \\
\hline White-tailed deer & $74.4^{\mathrm{A}^{*}}$ & $54.9^{\mathrm{B}}$ & $34.2^{\mathrm{C}}$ \\
Fruits and seeds & $6.2^{\mathrm{B}}$ & $8.7^{\mathrm{B}}$ & $46.3^{\mathrm{A}}$ \\
Plant material & $35.3^{\mathrm{B}}$ & $41.3^{\mathrm{AB}}$ & $46.3^{\mathrm{A}}$ \\
Small mammal & $20.0^{\mathrm{AB}}$ & $14.6^{\mathrm{A}}$ & $25.2^{\mathrm{B}}$ \\
Squirrels and chipmunks & $6.7^{\mathrm{A}}$ & $13.9^{\mathrm{B}}$ & $18.0^{\mathrm{B}}$ \\
Livestock & $8.4^{\mathrm{A}}$ & $2.9^{\mathrm{B}}$ & $12.6^{\mathrm{AB}}$
\end{tabular}

\footnotetext{
*Percent occurrence followed by the same uppercase letter within rows denotes no significant difference at the 0.05 alpha level.
} 
Table 2. Percent occurrence common items in coyote stomach samples in West Virginia during November 2009-June 2011. Sample size is in parentheses.

\begin{tabular}{lrrr}
\hline Item & Scat $(n=693)$ & Stomach $(n=276)$ & $P$-value \\
White-tailed deer & 54.8 & 71.4 & $<0.001$ \\
Plant material & 42.6 & 32.6 & 0.028 \\
Small mammal & 18.8 & 20.1 & 0.872 \\
Fruits and seeds & 19.2 & 8.3 & $<0.001$ \\
Squirrels and chipmunks & 13.9 & 5.1 & $<0.001$ \\
Livestock & 1.9 & 17.4 & $<0.001$ \\
\hline
\end{tabular}


Table 3. Percent occurrence comparisons between years of common items in coyote stomach samples in West Virginia, November 2009-June 2011. Sample size is in parentheses.

\begin{tabular}{lccc}
\hline Item & $\begin{array}{c}\text { January-June 2010 } \\
(n=246)\end{array}$ & $\begin{array}{c}\text { January-June 2011 } \\
(n=372)\end{array}$ & $P$-value \\
\hline Fruits and seeds & 3.3 & 8.1 & 0.013 \\
Plant material & 30.9 & 39.2 & 0.031 \\
Small mammal & 17.5 & 20.4 & 0.362 \\
Squirrels and chipmunks & 8.5 & 8.3 & 0.901 \\
Livestock & 7.7 & 6.7 & 0.601 \\
\hline
\end{tabular}


Table 4. Percent occurrence of common items in male and female coyote stomach samples in West Virginia, November 2009-June 2011. Sample size is in parentheses.

\begin{tabular}{lrrr}
\hline Item & $\begin{array}{c}\text { Males } \\
(n=110)\end{array}$ & $\begin{array}{r}\text { Females } \\
(n=135)\end{array}$ & $P$-value \\
\hline White-tailed deer & 70.9 & 74.1 & 0.134 \\
Fruits and seeds & 8.2 & 8.1 & 0.959 \\
Plant material & 30.0 & 31.9 & 0.738 \\
Small mammals & 19.1 & 23.7 & 0.476 \\
Squirrels and chipmunks & 8.2 & 3.7 & 0.118 \\
Livestock & 22.7 & 12.6 & 0.039 \\
& & & \\
\hline
\end{tabular}


Table 5. Percent occurrence of common items in coyote scat and stomach samples between adults ( $>1$ year) and juveniles ( $<1$ year) in West Virginia, November 2009-June 2011. Sample size is in parentheses.

\begin{tabular}{|c|c|c|c|}
\hline Item & $\begin{array}{c}\text { Juveniles }^{\mathrm{a}} \\
(n=171)\end{array}$ & $\begin{array}{l}\text { Adults }^{b} \\
(n=75)\end{array}$ & $P$-value \\
\hline White-tailed deer & 76.7 & 61.3 & 0.009 \\
\hline Fruits and seeds & 5.8 & 14.7 & 0.022 \\
\hline Plant material & 31.9 & 28.0 & 0.840 \\
\hline Small mammals & 19.8 & 20.0 & 0.958 \\
\hline Squirrels and chipmunks & 4.7 & 8.0 & 0.290 \\
\hline Livestock & 18.6 & 14.7 & 0.458 \\
\hline
\end{tabular}


Table 6. Percent occurrence of commonly items in coyote diets among regions in West Virginia, November 2009-June 2011. Sample size is in parentheses.

\begin{tabular}{|c|c|c|c|c|c|c|}
\hline Item & $\begin{array}{c}\text { Eastern } \\
\text { Panhandle } \\
(n=30)\end{array}$ & $\begin{array}{c}\text { Mountains } \\
(n=379)\end{array}$ & $\begin{array}{l}\text { Southern } \\
(n=309)\end{array}$ & $\begin{array}{c}\text { Central } \\
(n=105)\end{array}$ & $\begin{array}{c}\text { Northwestern } \\
\quad(n=94)\end{array}$ & $\begin{array}{l}\text { Western } \\
(n=32)\end{array}$ \\
\hline White-tailed deer & $73.3^{\mathrm{AC} *}$ & $74.0^{D}$ & $29.4^{\mathrm{B}}$ & $75.2^{\mathrm{AD}}$ & $75.5^{\mathrm{AD}}$ & $65.6^{\mathrm{AD}}$ \\
\hline Fruits and seeds & $13.3^{\mathrm{A}}$ & $4.5^{\mathrm{A}}$ & $39.2^{\mathrm{B}}$ & $3.8^{\mathrm{A}}$ & $5.3^{\mathrm{A}}$ & $9.3^{\mathrm{AB}}$ \\
\hline Plant material & $50.0^{\mathrm{AB}}$ & $47.8^{\mathrm{B}}$ & $34.3^{\mathrm{A}}$ & $39.0^{\mathrm{AB}}$ & $27.6^{\mathrm{B}}$ & $34.3^{\mathrm{AB}}$ \\
\hline Small mammal & $26.7^{\mathrm{AB}}$ & $13.5^{\mathrm{A}}$ & $23.6^{\mathrm{B}}$ & $26.7^{\mathrm{AB}}$ & $20.2^{\mathrm{AB}}$ & $18.7^{\mathrm{AB}}$ \\
\hline $\begin{array}{l}\text { Squirrels and } \\
\text { chipmunks }\end{array}$ & $0.0^{\mathrm{A}}$ & $5.5^{\mathrm{A}}$ & $24.9^{\mathrm{B}}$ & $4.7^{\mathrm{A}}$ & $4.2^{\mathrm{A}}$ & $9.3^{\mathrm{AB}}$ \\
\hline Livestock & $30.0^{\mathrm{A}}$ & $4.7^{\mathrm{BC}}$ & $3.6^{\mathrm{B}}$ & $4.7^{\mathrm{BC}}$ & $12.7^{\mathrm{AB}}$ & $15.6^{\mathrm{AC}}$ \\
\hline
\end{tabular}

Percent occurrence followed by the same uppercase letter within rows denotes no significant difference at the 0.05 alpha level. 
Table 7. Ranking matrix for proportional coyote diets in West Virginia, November 2009-June 2011. Each mean element was replaces by its sign; a triple sign indicates significant deviation from random at $P<0.05$. Items on the y (or vertical) axis are the primary comparison. For example, livestock is significantly less selected than deer if you are moving down the column, or deer is significantly more selected than livestock if you are moving across the row.

\begin{tabular}{|c|c|c|c|c|c|c|c|c|c|c|c|}
\hline Item & Deer & Livestock & $\begin{array}{c}\text { Small } \\
\text { mammal }\end{array}$ & $\begin{array}{c}\text { Fruits } \\
\text { and } \\
\text { seeds }\end{array}$ & $\begin{array}{l}\text { Squirrels and } \\
\text { chipmunks }\end{array}$ & Invertebrates & $\begin{array}{c}\text { Plant } \\
\text { material }\end{array}$ & $\begin{array}{l}\text { Amphibians } \\
\text { and reptiles }\end{array}$ & Birds & Trace & Rank \\
\hline Deer & 0 & +++ & +++ & +++ & +++ & +++ & +++ & +++ & +++ & +++ & 1 \\
\hline Livestock & --- & 0 & --- & --- & --- & + & --- & +++ & +++ & --- & 7 \\
\hline $\begin{array}{l}\text { Small } \\
\quad \text { mammals }\end{array}$ & --- & +++ & 0 & +++ & +++ & +++ & --- & +++ & +++ & --- & 4 \\
\hline $\begin{array}{c}\text { Fruits and } \\
\text { seeds }\end{array}$ & --- & +++ & --- & 0 & +++ & +++ & --- & +++ & +++ & --- & 5 \\
\hline $\begin{array}{l}\text { Squirrels and } \\
\text { chipmunks }\end{array}$ & --- & +++ & --- & --- & 0 & +++ & --- & +++ & +++ & --- & 6 \\
\hline Invertebrates & --- & - & --- & --- & --- & 0 & --- & +++ & +++ & --- & 8 \\
\hline Plant material & --- & +++ & +++ & +++ & +++ & +++ & 0 & +++ & +++ & - & 3 \\
\hline $\begin{array}{l}\text { Amphibians } \\
\text { and reptiles }\end{array}$ & --- & --- & --- & --- & --- & --- & --- & 0 & --- & --- & 10 \\
\hline Birds & --- & --- & --- & --- & --- & --- & --- & +++ & 0 & --- & 9 \\
\hline Trace & --- & +++ & +++ & +++ & +++ & +++ & + & +++ & +++ & 0 & 2 \\
\hline
\end{tabular}


Table 8. White-tailed deer distance survey results from the 3 counties of focus in West Virginia, November 2009-June 2011.

\begin{tabular}{lrrr}
\hline County & $\begin{array}{c}\text { Route } \\
\text { distance } \\
(\mathrm{km})\end{array}$ & $\begin{array}{c}\text { Coefficient } \\
\text { of variation }\end{array}$ & $\begin{array}{c}\text { Density estimate } \\
\left(\mathrm{deer} / \mathrm{km}^{2}\right)\end{array}$ \\
\hline Lewis & 91.1 & 0.21 & 7.24 \\
Pocahontas & 74.2 & 0.17 & 10.44 \\
Raleigh total & 178.8 & 0.51 & 4.77 \\
Raleigh bottomland & 68.7 & 0.18 & 8.24 \\
\hline
\end{tabular}




\section{FIGURE LEGENDS}

Figure 1. The 6 ecological regions and the 3 focus regions and counties in West Virginia (Uhlig and Wilson 1952) where coyote scat and stomach samples were collected during November 2009-June 2011.

Figure 2. The distribution of coyote samples $(\boldsymbol{\Delta})$ throughout West Virginia, November 2009June 2011.

Figure 3. Percent occurrence of common items in coyote scat and stomach samples among seasons in West Virginia, November 2009-June 2011. Percent occurrence is likelihood of an item being found in a sample, so total will not sum to 100.

Figure 4. Percent occurrence of common items in coyote diets among regions in West Virginia, November 2009-June 2011. Percent occurrence is likelihood of an item being found in a sample, so total will not sum to 100 .

Figure 5. Percent occurrence of deer in coyote diets among months in West Virginia, November 2009-June 2011. December was excluded due to small sample size. 


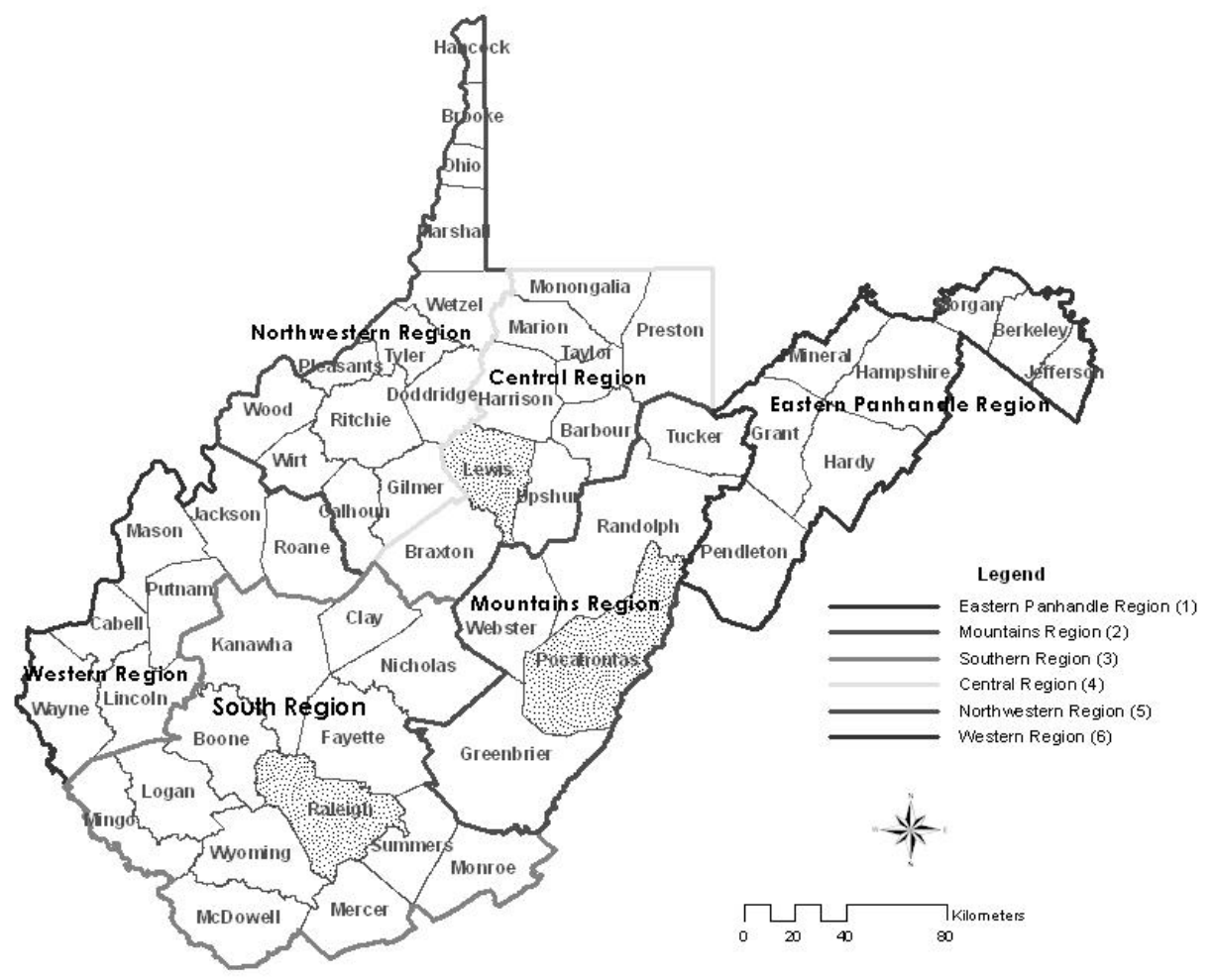




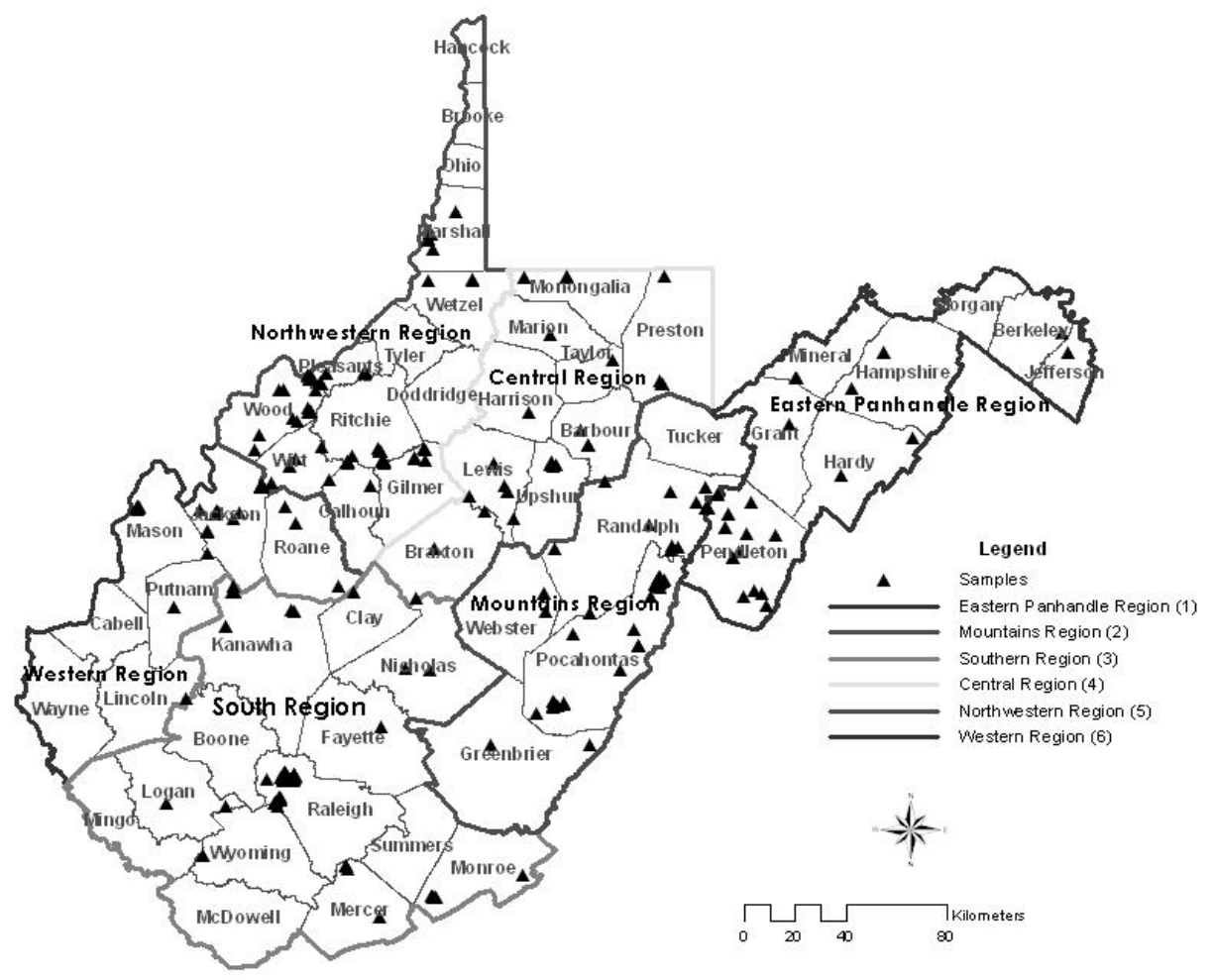




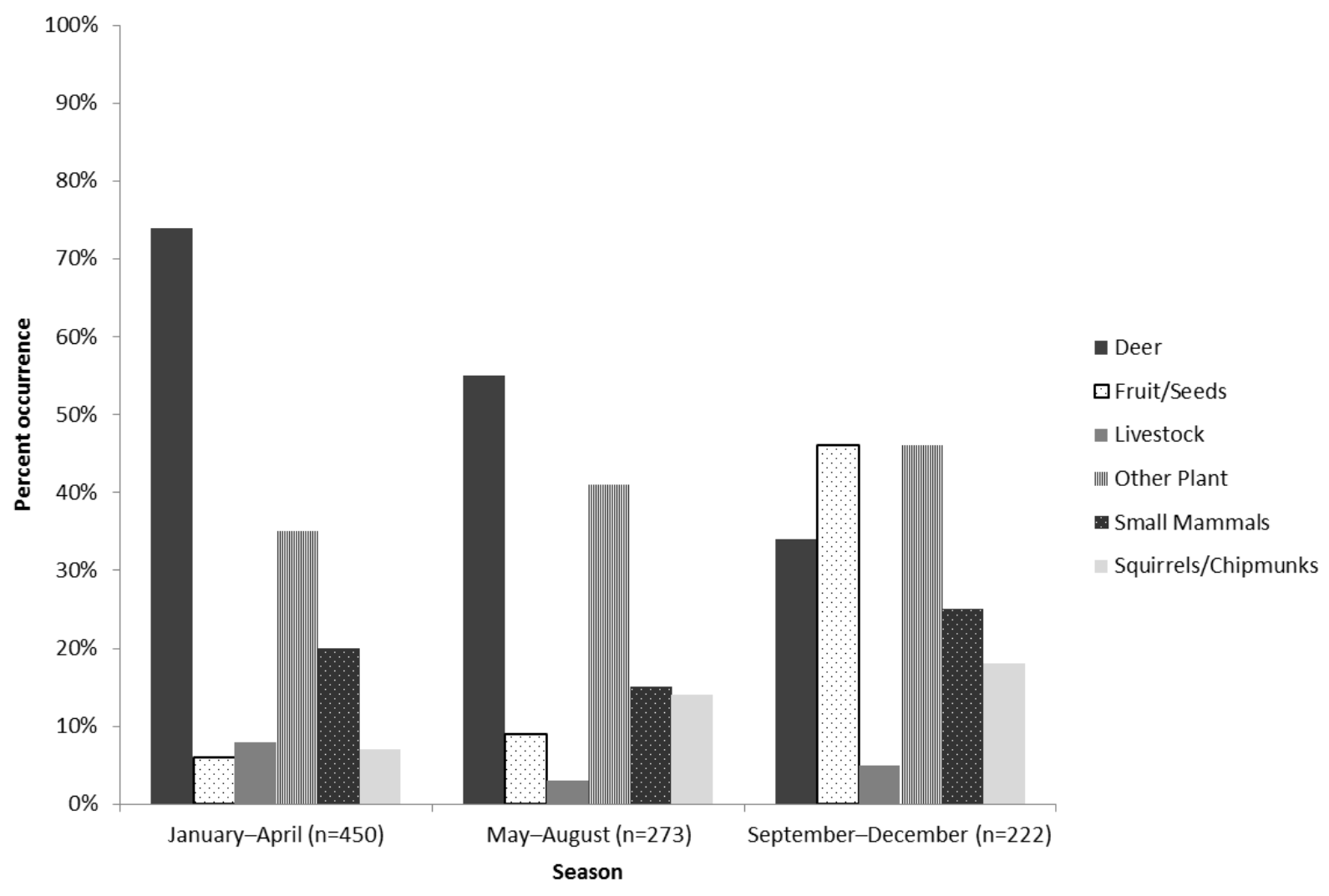




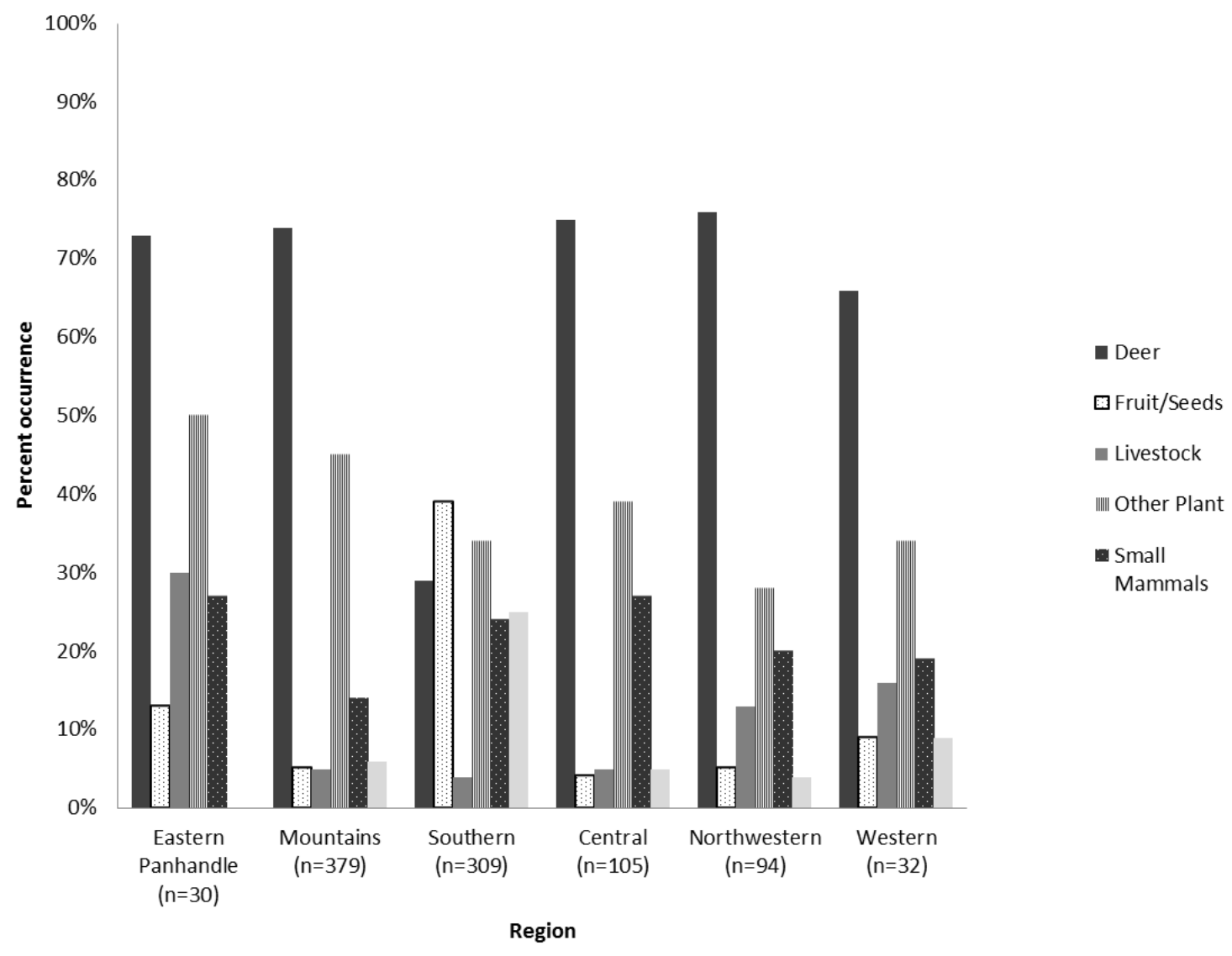




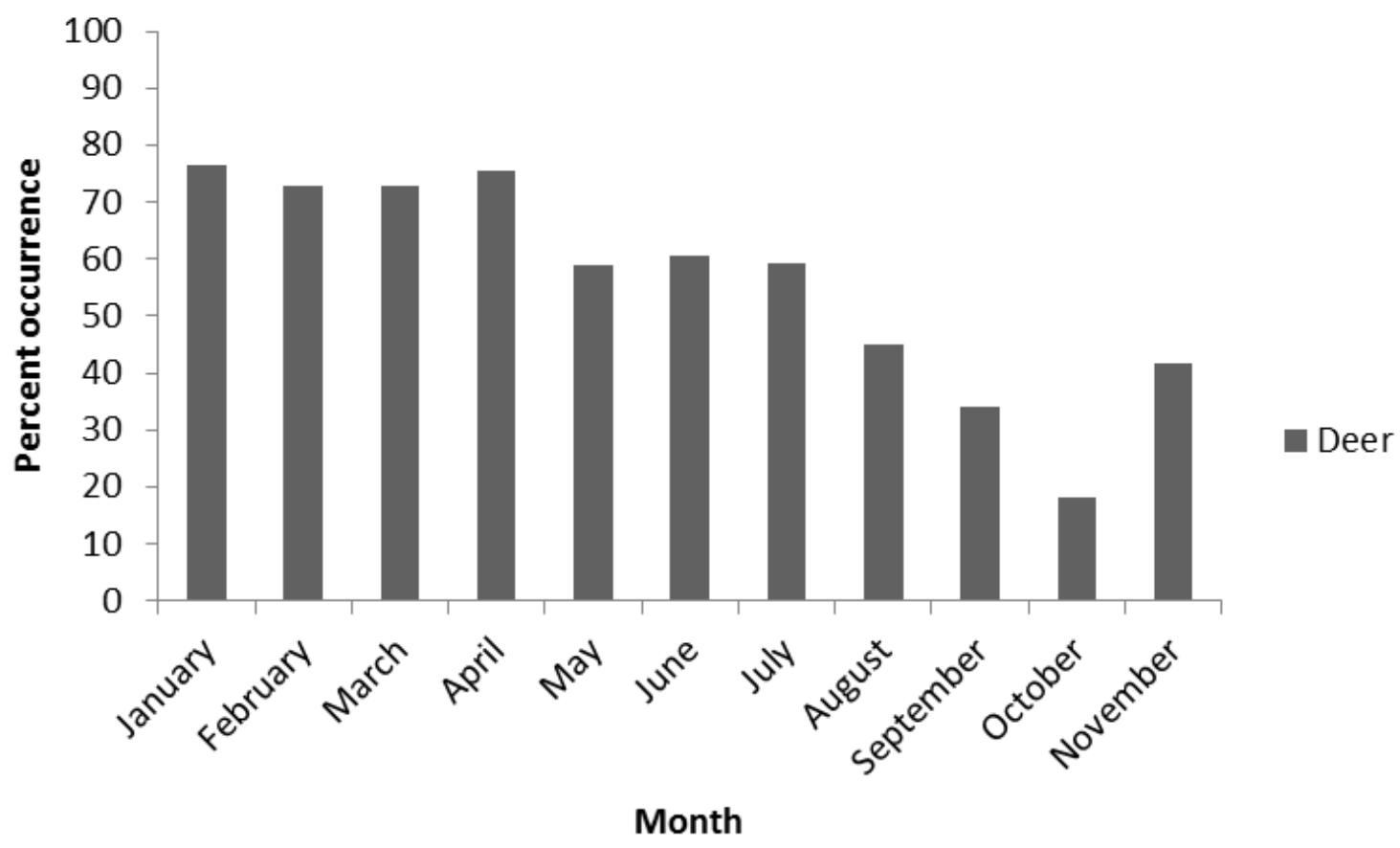




\section{CHAPTER 3}

\section{Livestock Occurrence in Diets of Coyotes in West Virginia}

(Formatted in the style of Journal of Wildlife Management) 


\section{CHAPTER 3}

\section{LIVESTOCK OCCURRENCE IN DIETS OF COYOTES IN WEST VIRGINIA}

April 2012

Geriann Albers

West Virginia University

322 Percival Hall

Morgantown, WV 26506

618/540-8556; Fax: 304/293-2441

galbers@mix.wvu.edu

RH: Albers et al. Livestock occurrence in the diets of coyotes in West Virginia

\section{Livestock occurrence in diets of coyotes in West Virginia}

GERIANN ALBERS, Division of Forestry and Natural Resources, West Virginia University, Morgantown, WV 26506, USA

JOHN W. EDWARDS, Division of Forestry and Natural Resources, West Virginia University, Morgantown, WV 26506, USA

LAUREN L. MASTRO, USDA APHIS Wildlife Services, National Wildlife Research Center, Elkins, $\quad$ WV 26241, USA

RICHARD E. ROGERS, West Virginia Division of Natural Resources, Romney, WV 26757, USA

ABSTRACT Coyotes (Canis latrans) are known predators of livestock and efforts have been made nation-wide to reduce these losses. In West Virginia, coyotes account for $63.6 \%$ of sheep and lambs killed by predators. Although studied in other parts of their range, coyote-livestock studies are limited in the mid-Atlantic region. Our objective was to compare the prevalence of wild items to livestock in coyote diets in West Virginia, and to look for trends in coyote consumption of livestock to aid managers in decisions regarding coyotes. In cooperation with West Virginia Division of Natural Resources, USDA APHIS Wildlife Services, and hunters and 
trappers, we collected coyote scats and stomachs throughout West Virginia during November 2009-June 2011. Livestock occurred in 6.3\% of coyote scat and stomach samples $(n=969)$. Natural items that occurred more frequently than livestock included white-tailed deer (Odocoileus virginianus; 59.5\%), plant material (39.7\%), small mammals (19.3\%), fruits and seeds (16.1\%), squirrels and chipmunks (11.4\%) and insects (6.8\%). Livestock constituted 3.1\% mean volume in coyote scat and stomach samples whereas natural items were $89.9 \%$ mean volume (remaining percent volume included unidentified material). Of the livestock found in coyote diets, cattle was the most frequently occurring at $4.2 \%$, followed by sheep (2.0\%), goats $(0.2 \%)$, and horse $(0.1 \%$; Table 9$)$. Within samples containing livestock, cattle was the most frequently occurring at $67 \%$, followed by sheep (34.4\%), goats (3.3\%), and horse (1.6\%). n stomach samples $(n=276)$, livestock occurred in $17.4 \%$ of samples, whereas it occurred in $1.9 \%$ found in scat samples $(n=693)$. Occurrence of livestock in samples was higher in JanuaryApril than May-August $(P=0.009)$, but was not significantly higher than September-December. Higher livestock occurrence during January-April and September-December coincides with lambing and calving in West Virginia. The Eastern Panhandle had the highest occurrence of livestock in coyote scat and stomach samples whereas the Southern Region had a lower frequency of livestock occurrence among regions in the state. Regional differences are possibly due to differing levels of livestock availability. Male coyotes were more likely to consume livestock than females, possibly a result of provisioning females and pups during pupping. KEY WORDS Canis latrans, cow, coyote, diet, lamb, livestock, sheep

Coyotes (Canis latrans) are known predators of domestic livestock. They account for the highest percentage of sheep and lamb predation nationally (USDA 2007). Coyotes are opportunistic and will prey upon cows, calves, sheep, lambs, goats, chickens, and other domestic 
animals (e.g., Fooks 1961, Slate 1987, Windberg et al. 1997, Sacks and Neale 2002, Mitchell et al. 2004). Numerous studies have been conducted which examine coyote predation on livestock (e.g., Murie 1951, Gier 1968, Jones and Woolf 1983, Till and Knowlton 1983, Blejwas et al. 2006), and new methods to protect livestock and reduce damage are in constant development (Mitchell et al. 2004).

The majority of coyote-livestock research has been conducted in the western United States. Few studies have been completed in the mid-Atlantic region, especially concerning coyote interactions with and depredation on livestock. An early record of coyote depredation from Virginia documents loss of livestock in the late 1960s (Carpenter 1971). In West Virginia, Taylor et al. (1976) reported a female coyote in Lewis County was responsible for extensive damage to sheep herds and subsequently killed. Coyote predation in West Virginia increased as coyotes became more common in the 1990s and in 1995 the West Virginia Integrated Predation Management Program (IPMP) was developed to address wildlife damage issues pertaining to livestock (Houben et al. 2004, Wildlife Service 2011). This program was developed by USDA APHIS Wildlife Services in conjunction with the West Virginia Department of Agriculture, the West Virginia Division of Natural Resources, the West Virginia Farm Bureau, the West Virginia Shepherd's Federation, livestock producers, and County Commissioners (Houben et al. 2004, Wildlife Services 2011).

Enhanced understanding of coyote ecology on both a regional and local scale is important for effective management. Research that furthers our understanding of coyote natural history and ecology can improve management abilities and efficiency. Our objective was to compare the prevalence of livestock in coyote diets in West Virginia to the prevalence of wild items. 
Moreover, we compared livestock occurrence in diets between age, sex, and sample type and among season and region.

\section{METHODS}

\section{Study Area}

We collected samples from 6 recognized ecological regions of West Virginia (Uhlig and Wilson 1952; Figure 6). Region 1 represents the Eastern Panhandle (Lithosol and shallow soils, 153 day average growing season, 52-54 degree average annual temperature, $30-40$ inches average annual precipitation, red oak (Quercus rubra) and hard pine-oak predominant forest cover type), Region 2 the Mountains Region (Podzol soils, 143 day average growing season, 4852 degree average annual temperature, 40-60 inches average annual precipitation, northern hardwoods and red oak predominant forest cover type), Region 3 the Southern Region (Podzols and lithosols soils, 173 day average growing season, 52-56 degree average annual temperature, 40-60 inches average annual precipitation, red oak and cove hardwoods predominant forest cover type), Region 4 the Central Region (Podzol soils, 155 day average growing season, 48-54 degree average annual temperature, 40-50 inches average annual precipitation, red oak and cove hardwoods predominant forest cover type, Region 5 the Northwestern Region (Lithosol and shallow soils, 165 day average growing season, 52-56 degree average annual temperature, 40-50 inches average annual precipitation, red oak predominant forest cover type), and Region 6 the Western Region (Lithosol and shallow soils, 171 day average growing season, 52-56 degree average annual temperature, 40-50 inches average annual precipitation, red oak and cove hardwoods predominant forest cover type). Our counties of focus for scat collection represented 3 of those regions: Southern Region (Raleigh County), Central Region (Lewis County) and Mountains Region (Pocahontas County; Figure 1). We collected scat in regions that had high 
participation of farms in USDA APHIS Wildlife Service's Intergrated Predation Management Program in order to supplement stomach collection in these regions to aid in addressing questions regarding livestock consumption by coyotes in West Virginia.

\section{Data Collection and Processing}

In cooperation with the West Virginia Division of Natural Resources (WVDNR), USDA APHIS Wildlife Services (WS), the West Virginia Trappers Association, and private citizens we collected coyote samples from November 2009 until June 2011. Samples included: stomachs from coyotes trapped by fur trappers and shot by hunters, scat collected from select properties, and animals trapped by WS as part of the Integrated Livestock Protection Program.

Stomachs. - We asked fur trappers and hunters to donate the stomachs and heads of harvested coyotes. We provided guides on how to remove the stomach and asked them to freeze samples. WS provided the carcasses of coyotes from throughout the state taken as part of the Integrated Predation Management Program. We asked contributors to provide the sex of the animal, and the date and location of harvest. We froze carcasses prior to processing, examined stomachs, and recorded all pertinent information recorded on tags affixed to coyotes provided by trappers, hunters, and Wildlife Service Specialists (e.g., sex, location collected, date trapped, collector's name). A lower canine tooth was removed from all skulls collected. To reduce costs, radiographs were taken of teeth and all animals that showed signs of root-tip closure (i.e. adults; Knowlton and Whittemore 2001) were sent to Matson's Lab (Milltown, MT) for cementum annuli aging (Matson 1981). We processed stomachs following Korschgen $(1969,1980)$. We thawed, rinsed through a mesh sieve, and dried stomach contents in a drying oven for approximately 24 hrs. We separated contents and identified bone, hair, plant material, insects, and feathers to the lowest taxonomic group possible. We compiled a reference collection of 
mammal fur, plant material and other potential food items. We compared hair collected from samples to both the reference collection and published guides by Spence (1963), Moore et al. (1974) and Teerink (1991), and compared feathers to a guide by Dove and Koch (2010). We determined volume using the point-frame method (Chamrad and Box 1964). Using a modification of Chamrad and Box (1964), a $5 \times 5$ grid was placed over the sample of stomach contents and the item present at each node was identified and recorded. The number of points at which each item occurred was recorded and multiplied by 4 to obtain a volume that summed to $100 \%$.

Scat.- Scat was collected by WVDNR on lands in counties (Lewis, Pocahontas, and Raleigh) representing 3 ecological regions (Appendix I). The Lewis County scat route on Stonewall Jackson Wildlife Management Area was primarily composed of mature oak-hickory (Quercus spp. and Carya spp.) forest with a hardwood understory and sparse herbaceous groundcover limited to the edges of the road. The Pocahontas County scat route on Monongahela National Forest had two segments. One segment traversed northern hardwood forests with no day-lighting of roads and sparse understory; the second segment also consisted of northern hardwoods, but with some day-lighting of roads and thick understory and herbaceous groundcover. The final scat route in Raleigh County located on private property covered a diversity of habitat types including mixed mature timber (e.g., Prunus spp. and Acer spp.), old strip-mine benches, early successional habitat (some along gas lines) with dense groundcover, and mature oak-hickory forest with a mountain laurel (Kalmia latifolia) understory. Although scat routes did not directly traverse farms, they were within coyote home range area to farmland.

Scat was collected along predetermined trails or roads and then frozen until processing. Scat collection took place during 3 seasons: (1) breeding (January-April), (2) pupping (May- 
August) and (3) dispersal (September-December). Sixteen (16) km of trail or road were sampled twice monthly in each county. Initially, all scats were cleared from the route so only fresh scats were collected. We processed scat following Korschgen $(1969,1980)$. We soaked scat overnight, then washed the scat through mesh sieves, and dried them in a drying oven for $>24$ hrs. We separated materials in samples and identified contents using the same procedure used for stomach contents. Volume was determined using the same point-frame method as described for stomach contents.

Statistical Analysis. - We used summary statistics (e.g., mean frequency, percentage) to report food item occurrence and volume in coyote diets, between scat and stomach samples, age class, sex, as well as among season, and regions. We calculated relative item occurrence by dividing the number of samples that contained an item by the number of samples [(number of items belonging to species $\mathrm{X}) /($ total number of items)*100, where the number of $\mathrm{X}$ items corresponds to the number of samples containing each item; Leopold and Krausman 1986, Corbett 1989]. We compared frequencies between age and sex and among seasons and regions using Kruskal-Wallis and Wilcoxon Pairwise comparison tests. Anthony and Smith (1974) showed scat and stomach content analysis yields comparable results, so for most comparisons we combined samples. For age and sex comparisons, only stomach samples were used as we did not have age and sex information for the coyote scat samples. Juveniles were defined as any animal $<1$ year of age. All statistics were completed using $\mathrm{R}_{\odot}($ The R Foundation for Statistical Computing, Vienna, Austria).

We generated a set of a priori multiple-competing hypotheses based on the body of peerreviewed literature on coyote diets. These hypotheses took the form of multiple logistic regression models to determine if the probability of livestock in coyote samples was related to 
region, age class, sex, or season. We used AICc (Akaike's Information Criterion corrected for small sample size (Burnham and Anderson 2002). Model selection was based on model weight and $\triangle \mathrm{AIC}$ values between $0-2$, which would suggest substantial support for a model. We used Akaike weights wAICc, to indicate the probability that a particular model was the best approximating model in the candidate set. Models with a $\Delta \mathrm{AIC}<10$ may have some support, but considerably less than those models with a $\triangle \mathrm{AIC}<2$ (Burnham and Anderson 2002). We focused on 2-way interactions as interactions greater than that can have limited interpretability and therefore limited use in management situations. A global model was used to estimate $\hat{c}$ to determine if overdispersion was present in the data (Burnham and Anderson 2002). We hypothesized that the probability of occurrence of livestock in coyote diets is a function of age of coyote, sex of coyote, region, season, or a subset of these variables. Additionally, we hypothesized that these factors may interact (e.g., female consumption of livestock may be different between adults and juveniles).

\section{RESULTS}

We analyzed 969 coyote scat and stomach samples from 40 of 55 counties (73\%) in West Virginia, including $n=693$ scat samples and $n=276$ stomach samples ( 5 unknown age and sex, 20 unknown sex juveniles, 6 unknown sex adults, 67 juvenile males, 34 adult males, 9 unknown age males, 84 juvenile females, 35 adult females, 16 unknown age females). The average number of items in a single sample (not including empty stomachs) was 2.2 items/sample (range 1-5 items). Livestock occurred in $6.3 \%$ of coyote scat and stomach samples. Natural items that occurred more frequently than livestock included white-tailed deer (Odocoileus virginianus; hereafter deer; 59.5\%), plant material (39.7\%), small mammals (19.3\%), fruits and seeds (16.1\%), squirrels and chipmunks (11.4\%) and insects (6.8\%; Appendix B). Anthropogenic 
items (i.e., livestock, cats, manmade material) constituted $3.6 \%$ mean volume $(3.1 \%$ livestock, $0.3 \%$ manmade, $0.2 \%$ cat) in coyote scat and stomach samples, whereas natural items were 89.9\% mean volume (remaining percent volume included unidentified material). Of the livestock found in coyote diets, cattle was the most frequently occurring at $4.2 \%$, followed by sheep $(2.0 \%)$, goats $(0.2 \%)$, and horse $(0.1 \%$; Table 9$)$. Within samples containing livestock, cattle was the most frequently occurring at $67 \%$, followed by sheep (34.4\%), goats $(3.3 \%)$, and hors (1.6\%). We also found 2 samples containing feathers that were likely poultry $(0.2 \%)$, though these were included with birds for analysis purposes as we could not confirm they were domestic poultry.

Coyote consumption of livestock differed among seasons $\left(\chi_{1}^{2}=9.41 ; P=0.009\right.$; Table 10; Figure 8) and regions $\left(\chi_{1}^{2}=45.15 ; P<0.001\right.$; Table 11; Figure 9). We found January-April (season 1) to have higher occurrence of livestock in scats and stomach samples than MayAugust (season 2; $P=0.009$ ). We found the Eastern Panhandle (Region 1) had the highest occurrence of livestock $(30.0 \%)$ in coyote scat and stomach samples compared to the other 5 regions. Coyotes in the Eastern Panhandle consumed higher amounts of livestock than the Mountains Region $(P<0.001)$, the Southern Region $(P<0.001)$, and the Central Region $(P<$ 0.001). The Southern Region had lower occurrence of livestock in coyote samples than the Northwestern $(P=0.012)$ and Western Regions $(P=0.040)$.

Livestock was found more frequently in coyote stomach samples $(17.4 \%, n=276)$ than in scat samples $(1.9 \%, n=693$; Table 9$)$. Male coyotes $(n=110)$ consumed more livestock than females $\left(n=135 ; \chi_{1}^{2}=4.27, P=0.039\right.$; Table 12$)$. Consumption of livestock between juveniles $(n=172)$ and adults $(n=75)$ was similar $\left(\chi_{1}^{2}=0.55, P=0.458\right.$; Table 13$)$. 
Global model fit of the data was adequate and overdispersion was not considered a concern $(\hat{\mathrm{c}}=0.81)$. Of our 12 candidate models (Table 16), the most supported models (i.e., competing) were sex and region $(w t=0.34, \Delta \mathrm{AICc}=0.00$, Table 14$)$, sex $(w t=0.27, \Delta \mathrm{AICc}=$ $0.47)$, and sex and age $(w t=0.12, \Delta \mathrm{AICc}=1.96)$.

\section{DISCUSSION}

We found coyotes in West Virginia consume primarily mammalian prey (e.g., whitetailed deer, squirrels and chipmunks, small mammals) and plant material, including fruits and seeds. Livestock was the seventh occurring diet item and had an associated low volume in samples. This indicates that coyotes are consuming livestock less frequently than other available items. This finding is supported by other coyote diet studies that often note livestock occurrence, but in relatively low amounts (e.g. Michaelson 1975, Grogan 1996, others) or do not occurr at all (Witmer et al. 1995). It also is supported by studies completed on wolves in Europe that showed wolves preyed upon wild ungulates more than livestock (Meriggi and Lovari 1996).

Coyotes consumed more livestock in January-April, which is also when the majority of lambing occurs in West Virginia (John Houben, USDA APHIS Wildlife Services, personal communication) and was the peak of trapping for USDA APHIS Wildlife Services personnel. Calving season is more dispersed throughout the year (5-7 months with peaks in early spring and fall), though some calving does occur during January-April (John Houben, USDA APHIS

Wildlife Services, personal communication). Because January-April is when the majority of preventative control efforts by USDA APHIS Wildlife Services occur (whereas corrective control occurs May-December; Wildlife Services 2011), and January-February was also the peak recreational trapping season (though coyote hunting is allowed year-round), $82 \%$ of our samples $(n=191)$ were trapped during January-April. It is unclear if increased occurrence of 
livestock in coyote scat and stomach samples was the result of increased trapping effort or if higher livestock predation or scavenging of livestock occurred during January-April.

Differing levels of livestock production among regions may influence the availability of cattle and sheep. Gier (1968) and Boggess et al. (1978) noted that livestock loss in areas often parallels availability of livestock. The Eastern Panhandle had the highest inventory of cattle (including calves, $n=111,791$ ) and sheep (including lambs, $n=13,407$ ) in the state in 2007 (NASS 2011) and had correspondingly higher occurrence of livestock in samples. Pendleton County in the Eastern Panhandle had 24,314 cattle and calves and 5,784 sheep and lambs alone in 2007, and it represented over half (52\%) of the Eastern Panhandle samples. Though our sample size in the region was prohibitive to look for more distinct trends, it is interesting to note the possible connection between availability of livestock and the occurrence of livestock in coyote scat and stomach samples. The Southern Region had lower inventories of livestock when compared to the Eastern Panhandle (Table 15; NASS 2011) and had the lowest occurrence of livestock in samples. It is possible that more readily available items such as squirrels and chipmunks or fruit in the Southern Region may be acting as a buffer to livestock predation in that region, as other studies have suggested some items such as fruit and small mammals may act as predation buffers (e.g. Niebauer 1974, Michaelson 1975, Sacks and Neale 2002). This effect may even be compounded by the lower inventory of livestock in the Southern Region.

We found higher occurrence of livestock in stomachs than in scat samples. This may be due to scat collection occurring primarily in non-agricultural areas whereas samples from USDA APHIS Wildlife Services were obtained from farms. All scat routes were within the area of a coyote home range from farms (typically $1-2 \mathrm{~km}$ ), but did not traverse through farms. Moreover, we did find livestock in scats, and several items still occurred more frequently than 
livestock in stomach samples, so livestock likely was neither biasing stomach sample results nor was livestock only present in stomach samples.

We found no differences in occurrence of livestock in diets between age classes. Some studies have suggested breeding animals are more likely to prey upon livestock (Connolly et al. 1976, Wagner and Conover 1999, Blejwas et al. 2006), whereas others suggest that younger animals are more likely to prey upon livestock due to their inexperience in hunting (see Linnell et al. 1999 for review). Though not significantly different, we found that 16 juvenile male coyotes, 4 adult males, 8 juvenile females and 2 adult females consumed livestock. During our examination of animals collected for this study, we found females were breeding in their first year (G. Albers, West Virginia University, unpublished data). It is therefore likely males also are breeding in their first year. However, due to our small sample sizes and lack of information regarding breeding in juvenile males in the West Virginia, we cannot speculate as to whether juvenile males were also breeding males.

Our best model (sex and region) in predicting the occurrence of livestock in coyote diets only had 1.25 times more support than the second best model. Additionally the best model had 2.8 times more support than the third best model. As suggested by Anderson (2008), it is possible in such an instance that region and season may be a "pretender variable" due to penalty factors involved in AIC. Because all 3 of the models contained the variable sex of coyote, we felt justified to select model 2 (sex of coyote) as our best model as it was the most parsimonious model. Sex was an important variable in all 3 best supported models, so our conclusion is that sex of the coyote best explains the occurrence of livestock found in coyote diets. Based on our results, region and season may have some effect on the probability of coyotes consuming livestock, but due to insufficient sample size in certain regions, the overall effect of region and 
season remains difficult to explain. Based on our most parsimonious model (probability of livestock in a coyote's diet is a function of the sex of that coyote), males were 2.29 times more likely to have livestock in their stomachs than females.

Our finding that male coyotes consumed more livestock than female coyotes has been reported in other studies (Connolly et al. 1976, Windberg et al. 1997, Linnell et al. 1999, Blejwas et al. 2006). Blejwas et al. (2006) used salivary DNA and telemetry to determine that 21 of 25 sheep kills involved breeding males, breeding females aided in 13 kills, transient females killed no sheep, and 2 transient males participated in kills. The behavior of males predating livestock more frequently than females also occurs in other predator species. Male jaguars (Panthera onca) in Belize constituted 77\% of the "problem" animals that killed domestic livestock (Rabinowitz 1986). In Norway, male Eurasian lynx (Lynx lynx) killed sheep more often than females and were responsible for $92 \%$ of surplus killing incidences (12/13; Odden et al. 2002). Stahl et al. (2001) in France found removal of male lynx temporarily resulted in reduced predation upon sheep.

Although some studies have noted the trend of males consuming or predating more livestock than females, the reasons for this remain speculative. Both Rabinowitz (1986) and Odden et al. (2002) suggest that male killing may be "intrinsic in their behavior". In West Virginia, it is possible males may kill livestock to provision females with pups during the denning season when females are more confined to dens to nurse altricial pups. Occurrence of livestock in samples was highest during January-April, and coyotes generally give birth from March-May (Bekoff and Gese 2003), which would support this hypothesis. The mechanisms behind sex-influenced predation are difficult to study, but important to consider in management decisions. 
Livestock predation is an issue of concern throughout the world because of the potential economic loss and the resulting human-wildlife conflicts (e.g., Yom-Tov et al. 1995, Mishra 1997, Stahl et al. 2001a, Patterson 2004, Cascelli de Azevedo 2008). Our findings suggest regional variation in the occurrence of livestock in coyote scat and stomach samples may be at least partially explained by availability of livestock in those regions. West Virginia is not one of the larger livestock producing states in the United States with an estimated 190,000 head of cattle and 30,000 sheep (NASS 2011), but shepherds and cattlemen with less numbers of livestock can be more susceptible to losses by predators (Schiess-Meier et al. 2007) and experience relatively greater economic loss.

Overall, livestock occurrence in scat and stomach samples of coyotes in West Virginia was lower than natural food items. We found male coyotes consumed livestock more frequently than females and although not significantly different, juvenile males consumed relatively higher amounts of livestock than adult males, adult females, and juvenile females.

\section{ACKNOWLEDGMENTS}

We would like to acknowledge our funding sources, West Virginia University Division of Forestry, the West Virginia Division of Natural Resources, USDA APHIS Wildlife Services, and The Berryman Institute. Thank you to USDA APHIS Wildlife Services staff, West Virginia Division of Natural Resources personnel, hunters, trappers, and the West Virginia Trappers Association for assistance in sample collection. Thank you to A. N. Tri and J. Q. Burkhardt for statistical advice, and M. D. Jones, A. N. Tri, and J. L. Berl for critical review. Thanks to all volunteers, interns, and technicians who aided in sample processing, especially L. C. Moon. 


\section{LITERATURE CITED}

Anderson, D. R. 2008. Model based inference in the life sciences: A primer on evidence. Springer Science and Buisness Media, New York, New York, USA.

Anthony, R. G., and N. S. Smith. 1974. Comparison of rumen and fecal analysis to describe deer diets. Journal of Wildlife Management 38:535-540.

Bekoff, M., and E. M. Gese. 2003. Coyote (Canis latrans). Pages 467-481 in G.A. Feldhammer, C. Thompson, J. A. Chapman (editors). Wild Mammals of North America: Biology, Management, and Conservation. Second edition. Johns Hopkins University Press, Baltimore, Maryland, USA.

Blejwas, K. M., C. L. Williams, G. T. Shin, D. R. McCullough, and M. M. Jaeger. 2006. DNA evidence convicts breeding male coyotes of killing sheep. Journal of Wildlife Management 70:1087-1093.

Boggess, E. K., R. D. Andrews, and R. A. Bishop. 1978. Domestic animal losses to coyote and dogs in Iowa. Journal of Wildlife Management 42:362-372.

Burnham, K. P., and D. R. Anderson. 2002. Model selection and multimodel inference: A practical information-theoretic approach. Springer-Verlag, New York, New York, U.S.A.

Cascelli de Azevedo, F. C. 2008. Food habits and livestock depredation of sympatric jaguars and pumas in the Iguaçu National Park area, South Brazil. Biotropica 40:494-500.

Carpenter, M. 1971. Some recent coyote records in Virginia. Virginia Wildlife 32:14-15.

Chamrad, A. D., and T. W. Box. 1964. A point frame for sampling rumen contents. Journal of Wildlife Management 28:473-477. 
Connolly, G. E., R. M. Timm, W. E. Howard, and W. M. Longhurst. 1976. Sheep killing behavior of captive coyotes. Journal of Wildlife Management 40:400-407.

Corbett, L. K. 1989. Assessing the diet of dingoes from feces: a comparison of 3 methods. Journal of Wildlife Management 53:343-346.

Dove, C. J., and S. L Koch. 2010. Microscopy of feathers: A practical guide for forensic feather identification. Journal of the American Society of Trace Evidence Examiners 1:15-61.

Fooks, L. G. 1961. Food habits of indigenous Canidae and Felidae in Arkansas based on complete and sample analyses of stomach contents. Thesis, University of Arkansas, Fayetteville, USA.

Gier, H. T. 1968. Coyotes in Kansas. Kansas State College Agriculture Experimental Station Bulletin 393, Manhattan, USA.

Grogan, M. E. 1996. Feeding strategies of the coyote (Canis latrans) in western Tennessee. Thesis, University of Memphis, Tennessee, USA.

Houben, J. M., W. R. Bonwell, and T. R. McConell. 2004. Development of the West Virginia Integrated Predation Management Program to protect livestock. Proceedings of the Vertebrate Pest Conference 21:71-74.

Jones, J. M., and A. Woolf. 1983. Relationship between husbandry practices and coyote use of swine in west central Illinois. Wildlife Society Bulletin 11:133-135.

Jorgensen, C. J. 1983. Bear-sheep interactions, Targhee National Forest. Bears: Their Biology and Management 5:191-200.

Korschgen, L. J. 1969. Procedures for food habit analysis. Pages 233-250 in R.H. Giles, Jr. (editor). Wildlife Management Techniques. The Wildlife Society, Washington, D.C., USA. 
Korschgen, L. J. 1980. Procedures for food habit analysis. Pages 113-127 in R.H. Giles, Jr. (editor). Wildlife Management Techniques. The Wildlife Society, Washington, D.C., USA.

Linnell, J. D. C., J. Odden, M. E. Smith, R. Aanes, and J. E. Swenson. Large carnivores that kill livestock: do "problem animals" really exist? Wildlife Society Bulletin 27:698-705.

Leopold, B. D., and P. R. Krausman. 1986. Diets of 3 predators in Big Bend National Park, Texas. Journal of Wildlife Management 50:290-295.

Matson, G. M. 1981. Workbook for cementum analysis. Matson's, Milltown, Montana, USA.

Meriggi, A., and S. Lovari. 1996. A review of wolf predation in Southern Europe: does the wolf prefer wild prey to livestock? Journal of Applied Ecology 33:1561-1571.

Michaelson, K. A. 1975. Food habits of coyotes in northwest Louisiana. Thesis, Louisiana Tech University, Ruston, USA.

Mishra, C. 1997. Livestock depredation by large carnivores in the Indian trans-Himalaya: conflict perceptions and conservation prospects. Environmental Conservation 24:338343.

Mitchell, B. R., M. M. Jaeger, R. H. Barrett. 2004. Coyote depredation management: Current methods and research needs. Wildlife Society Bulletin 32:1209-1218.

Moore, T. D., C.E. Dugnolle, and L. E. Spence. 1974. Identification of the dorsal guard hairs of some mammals of Wyoming. Wyoming Game and Fish Department Bulletin No. 14. Cheyenne, Wyoming, USA.

Murie, A. 1951. Coyote food habits on a southwestern cattle range. Journal of Mammalogy 32:291-295. 
National Agricultural Statistics Service [NASS]. 2011. Quick Stats: Cattle and Sheep Inventories. http://quickstats.nass.usda.gov/. Accessed 4 Jan 2012.

Niebauer, T. J. 1974. Coyote food habits in northwestern Wisconsin. Thesis, University of Wisconsin, Madison, USA.

Odden, J., J. D. C. Linnell, P. F. Moa, I. Herfindal, T. Kvam, and R. Andersen. 2002. Lynx depredation on domestic sheep in Norway. Journal of Wildlife Management 66:98-105.

Patterson, B. D., S. M. Kasiki, E. Selempo, and R. W. Kays. 2004. Livestock predation by lions (Pantera leo) and other carnivores on ranches neighboring Tsavo National Parks, Kenya. Biological Conservation 119:507-516.

Rabinowitz, A. R. 1986. Jaguar predation on domestic livestock in Belize. Wildlife Society Bulletin 14:170-174.

Sacks, B. N., and J. C. C. Neale. 2007. Coyote abundance, sheep predation, and wild prey correlates illuminate Mediterranean trophic dynamics. Journal of Wildlife Management 71:2404-2411.

Schiess-Meier, M., S. Ramsauer, T. Gabanapelo, and B. König. 2007. Livestock predationinsights from problem animal control registers in Botswana. Journal of Wildlife Management 71:1267-1274.

Slate, D. L. 1987. Coyotes in the Eastern US: Status and implications. Proceedings of the Eastern Wildlife Damage Control Conference 3:325-326.

Spence, L. E. 1963. Study for identifying characteristics of mammal hair. Wyoming Game and Fish Commission Job Completion Report Project FW 3-R-10, Work Plan No. 10, Job No. 2W, Laramie, USA. 
Stahl, P., J. M. Vandel, V. Herrenschmidt, and P. Migot. 2001a Predation on livestock by an expanding reintroduced lynx population: Long-term trend and spatial variability. Journal of Applied Ecology 38:674-687.

Stahl, P., J. M. Vandel, V. Herrenschmidt, and P. Migot. 2001b. The effect of removing lynx in reducing attacks on sheep in the French Jura Mountains. Biological Conservation 101:15-22.

Taylor, R. W., C. L. Counts III, and S. B. Mills. 1976. Occurrence and distribution of the coyote (Canis latrans) in West Virginia. Proceedings of the West Virginia Academy of Science 48:73-77.

Teerink, B. J. 1991. Hair of West-European mammals. Cambridge University Press, Cambridge, United Kingdom.

Till, J. A., and F. F. Knowlton. 1983. Efficacy of denning in alleviating coyote depredations upon domestic sheep. Journal of Wildlife Management 47:1018-1025.

Uhlig, H. G., and H. L Wilson. 1952. A method of evaluating an annual mast index. Journal of Wildlife Management 16:338-343.

USDA. 2007. Sheep and lamb predator death loss in the United States, 2004. USDA-APHIS-VS-CEAH, National Animal Health Monitoring System, Fort Collins, CO, USA.

Wagner, K. K., and M. R. Conover. 1999. Effect of preventive coyote hunting on sheep losses to coyote predation. Journal of Wildlife Management 63:606-612.

Wildlife Services. 2011. West Virginia integrated predation management program: 2011 annual report. United States Department of Agriculture, Animal and Plant Health Inspection Service, Wildlife Services, Elkins, West Virginia, USA. 
Windberg, L. A., F. F. Knowlton, S. M. Ebbert, and B. T. Kelly. 1997. Aspects of coyote predation on angora goats. Journal of Range Management 50:226-230.

Witmer, G. W., M. J. Pipas, and A. Hayden. 1995. Some observations on coyote food habits in Pennsylvania. Journal of the Pennsylvania Academy of Science 69:77-80.

Yom-Tov, Y., S. Ashkenazi, and O. Viner. 1995. Cattle predation by the golden jackal Canis aureus in the Golan Heights, Israel. Biological Conservation 73:19-22. 
Table 9. Percent occurrence of livestock in coyote scat and stomach samples collected in West Virginia, November 2009-June 2011. Sample size is in parentheses.

\begin{tabular}{lrrr}
\hline Item & $\begin{array}{c}\text { Scat } \\
(n=693)\end{array}$ & $\begin{array}{c}\text { Stomachs } \\
(n=276)\end{array}$ & $\begin{array}{c}\text { Overall } \\
(n=969)\end{array}$ \\
\hline Cow & 1.6 & 10.9 & 4.2 \\
Sheep & 0.3 & 6.2 & 2.0 \\
Horse & 0.0 & 0.4 & 0.1 \\
Goat & 0.0 & 0.7 & 0.2 \\
Total & 1.9 & 17.4 & 6.3 \\
\hline
\end{tabular}


Table 10. Percent occurrence of livestock in coyote scat and stomach samples for season in West Virginia, November 2009-June 2011. Columns may not sum as goat and horse was excluded due to low occurrence in samples. Sample size is in parentheses.

\begin{tabular}{lccc}
\hline Item & $\begin{array}{c}\text { January-April } \\
\text { Season 1 } \\
(n=450)\end{array}$ & $\begin{array}{c}\text { May-August } \\
\text { Season 2 } \\
(n=273)\end{array}$ & $\begin{array}{c}\text { September-December } \\
\text { Season 3 } \\
(n=222)\end{array}$ \\
\hline Cow & 6.0 & 2.6 & 2.3 \\
Sheep & 2.2 & 0.4 & 3.1 \\
Total livestock & $8.4^{\mathrm{A}^{*}}$ & $2.9^{\mathrm{B}}$ & $5.4^{\mathrm{AB}}$
\end{tabular}

\footnotetext{
* Percent occurrence followed by the same uppercase letter within rows denotes no significant difference at the 0.05 alpha level
} 
Table 11. Percent occurrence of livestock in coyote scat and stomach samples for region in West Virginia, November 2009-June 2011. Columns may not sum as goat and horse was excluded due to low occurrence in samples. Sample size is in parentheses.

\begin{tabular}{lcccccc}
\hline Item & $\begin{array}{c}\text { Eastern } \\
\text { Panhandle } \\
(n=30)\end{array}$ & $\begin{array}{c}\text { Mountains } \\
(n=379)\end{array}$ & $\begin{array}{c}\text { Southern } \\
(n=309)\end{array}$ & $\begin{array}{c}\text { Central } \\
(n=105)\end{array}$ & $\begin{array}{c}\text { Northwestern } \\
(n=94)\end{array}$ & $\begin{array}{c}\text { Western } \\
(n=32)\end{array}$ \\
\hline Cow & 13.3 & 2.6 & 2.9 & 3.8 & 10.6 & 12.5 \\
Sheep & 16.7 & 2.1 & 0.6 & 0.0 & 2.1 & 3.1 \\
Total & $30.0^{\mathrm{A}^{*}}$ & $4.7^{\mathrm{BC}}$ & $3.6^{\mathrm{C}}$ & $4.8^{\mathrm{BC}}$ & $12.8^{\mathrm{AB}}$ & $15.6^{\mathrm{AB}}$
\end{tabular}

* Percent occurrence followed by the same uppercase letter within rows denotes no significant difference at the 0.05 alpha level 
Table 12. Percent occurrence of livestock in male and female coyote scat and stomach samples in West Virginia, November 2009-June 2011. Columns may not sum as goat and horse was excluded due to low occurrence in samples. Sample size is in parentheses.

\begin{tabular}{lrrr}
\hline Item & $\begin{array}{c}\text { Male } \\
(n=110)\end{array}$ & $\begin{array}{c}\text { Female } \\
(n=135)\end{array}$ & $P$-value \\
\hline Cow & 16.4 & 7.4 & \\
Sheep & 5.5 & 4.4 & \\
Total & 22.7 & 12.6 & 0.039 \\
& & & \\
\hline
\end{tabular}


Table 13. Percent occurrence of livestock in coyote diets between age classes in West Virginia, November 2009-June 2011. Columns may not sum as goat and horse was excluded due to low occurrence in samples. Sample size is in parentheses.

\begin{tabular}{lrrr}
\hline Item & $\begin{array}{r}\text { Juveniles }^{\mathrm{a}} \\
(n=171)\end{array}$ & $\begin{array}{c}\text { Adults }^{\mathrm{b}} \\
(n=75)\end{array}$ & $P$-value \\
\hline Cow & 6.3 & 14.8 & \\
Sheep & 4.2 & 3.7 & \\
Total & 12.5 & 18.5 & 0.458 \\
& & & \\
\hline $\begin{array}{l}\text { a animal less than 1 year in age } \\
\mathrm{b} \text { animal greater than 1 year in age }\end{array}$
\end{tabular}


Table 14. Candidate models and results of logistic regression of livestock occurrence in coyote diets in West Virginia, November 2009-June 2011.

\begin{tabular}{lrrrrrr}
\hline Model & K & AICc & $\Delta$ AIC & AICc Weight & Cumulative Weight & Log Likelihood \\
\hline Sex + Region & $\mathbf{7}$ & $\mathbf{1 9 2 . 3 0}$ & $\mathbf{0 . 0 0}$ & $\mathbf{0 . 3 4}$ & $\mathbf{0 . 3 4}$ & $\mathbf{- 8 8 . 8 7}$ \\
Sex & $\mathbf{2}$ & $\mathbf{1 9 2 . 7 6}$ & $\mathbf{0 . 4 7}$ & $\mathbf{0 . 2 6}$ & $\mathbf{0 . 5 9}$ & $\mathbf{- 9 4 . 3 5}$ \\
Sex + Age & $\mathbf{3}$ & $\mathbf{1 9 4 . 2 6}$ & $\mathbf{1 . 9 6}$ & $\mathbf{0 . 1 2}$ & $\mathbf{0 . 7 1}$ & $\mathbf{- 9 4 . 0 7}$ \\
Region & 6 & 194.74 & 2.44 & 0.10 & 0.81 & -91.16 \\
Sex + Season & 4 & 195.90 & 3.60 & 0.05 & 0.87 & -93.85 \\
Sex $\times$ Age & 4 & 196.14 & 3.85 & 0.05 & 0.91 & -93.97 \\
Global & 10 & 197.45 & 5.15 & 0.03 & 0.94 & -88.16 \\
Age & 2 & 197.59 & 5.30 & 0.02 & 0.96 & -96.77 \\
Sex $\times$ Region & 12 & 198.19 & 5.89 & 0.02 & 0.98 & -86.29 \\
Season & 3 & 199.15 & 6.85 & 0.01 & 0.99 & -96.52 \\
Age $\times$ Season & 6 & 200.64 & 8.34 & 0.01 & 1.00 & -94.11 \\
Age + Season & 4 & 200.78 & 8.48 & 0.00 & 1.00 & -96.29 \\
\hline
\end{tabular}


Table 15. Inventory of cattle, calves, sheep and lambs among regions within West Virginia in 2007 as reported by the USDA National Agriculture Statistics Services QuickStats program.

Region Cattle and calf inventory Sheep and lamb inventory

\begin{tabular}{lcc}
\hline Eastern Panhandle (1) & 111,791 & 13,407 \\
Mountains (2) & 62,655 & 8,904 \\
Southern (3) & 55,740 & 3,500 \\
Central (4) & 84,499 & 6,661 \\
Northwestern (5) & 50,364 & 3,473 \\
Western (6) & 45,979 & 1,989 \\
\hline
\end{tabular}




\section{FIGURE LEGENDS}

Figure 6. The 6 ecological regions and the 3 focus regions and counties in West Virginia (Uhlig and Wilson 1952) used for the coyote diet study.

Figure 7. The distribution of coyote scat and stomach samples throughout West Virginia, November 2009-June 2011.

Figure 8. Percent occurrence of livestock in coyote samples among seasons in West Virginia, November 2009-June 2011. Percent occurrence is likelihood of an item being found in a sample, so total will not sum to 100.

Figure 9. Percent occurrence of livestock in coyote stomach and scat samples among regions in West Virginia, November 2009-June 2011. Percent occurrence is likelihood of an item being found in a sample, so total will not sum to 100. 


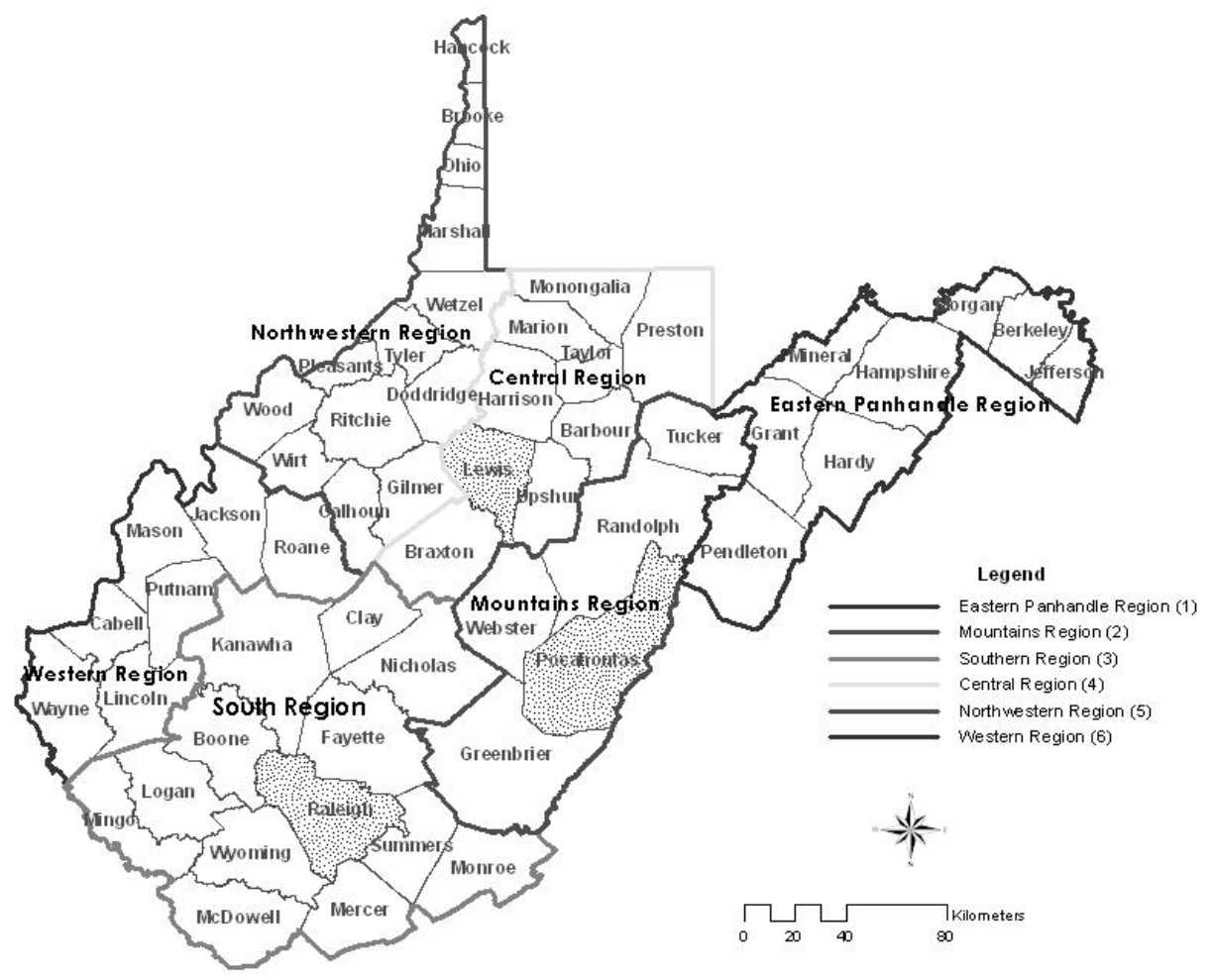




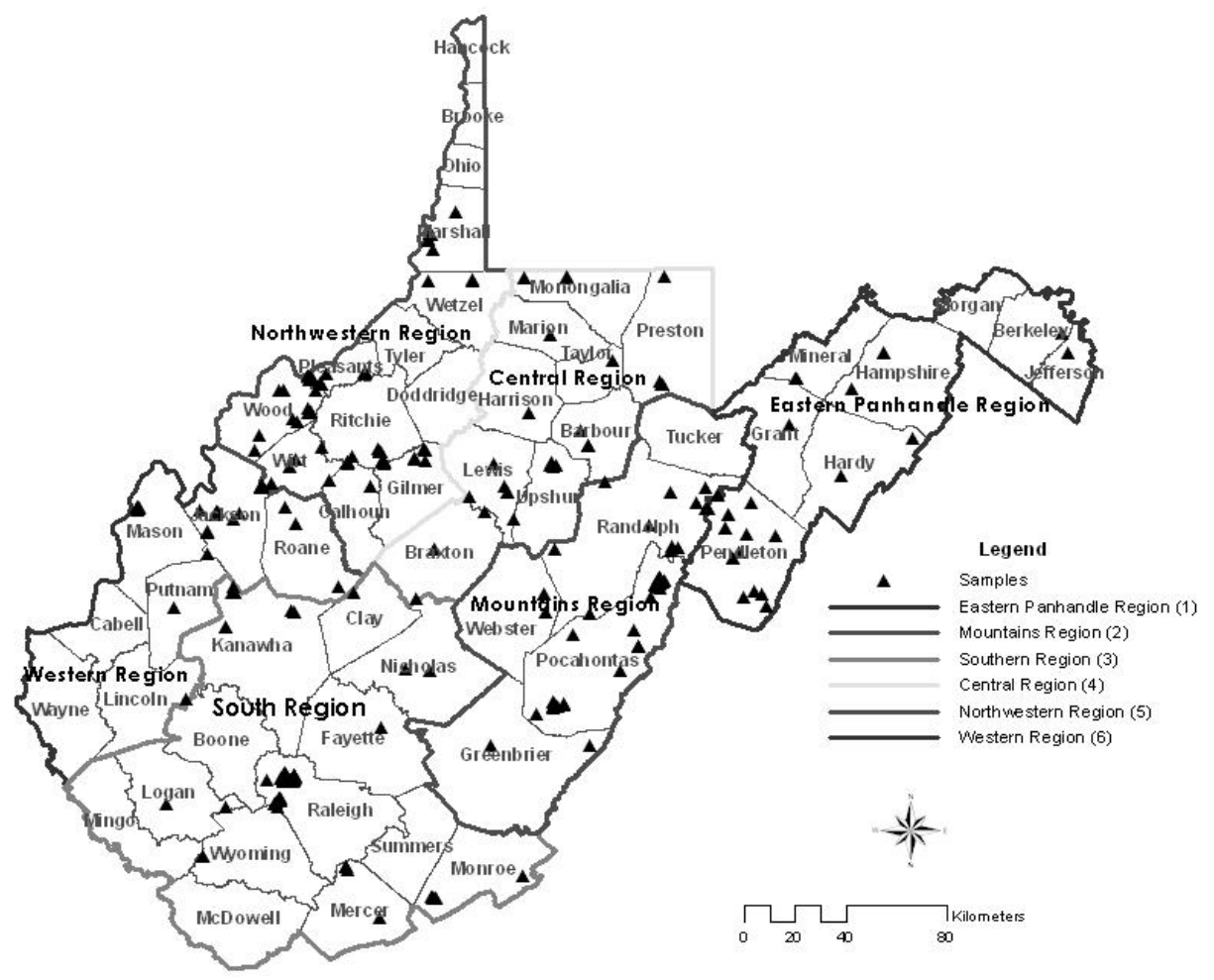




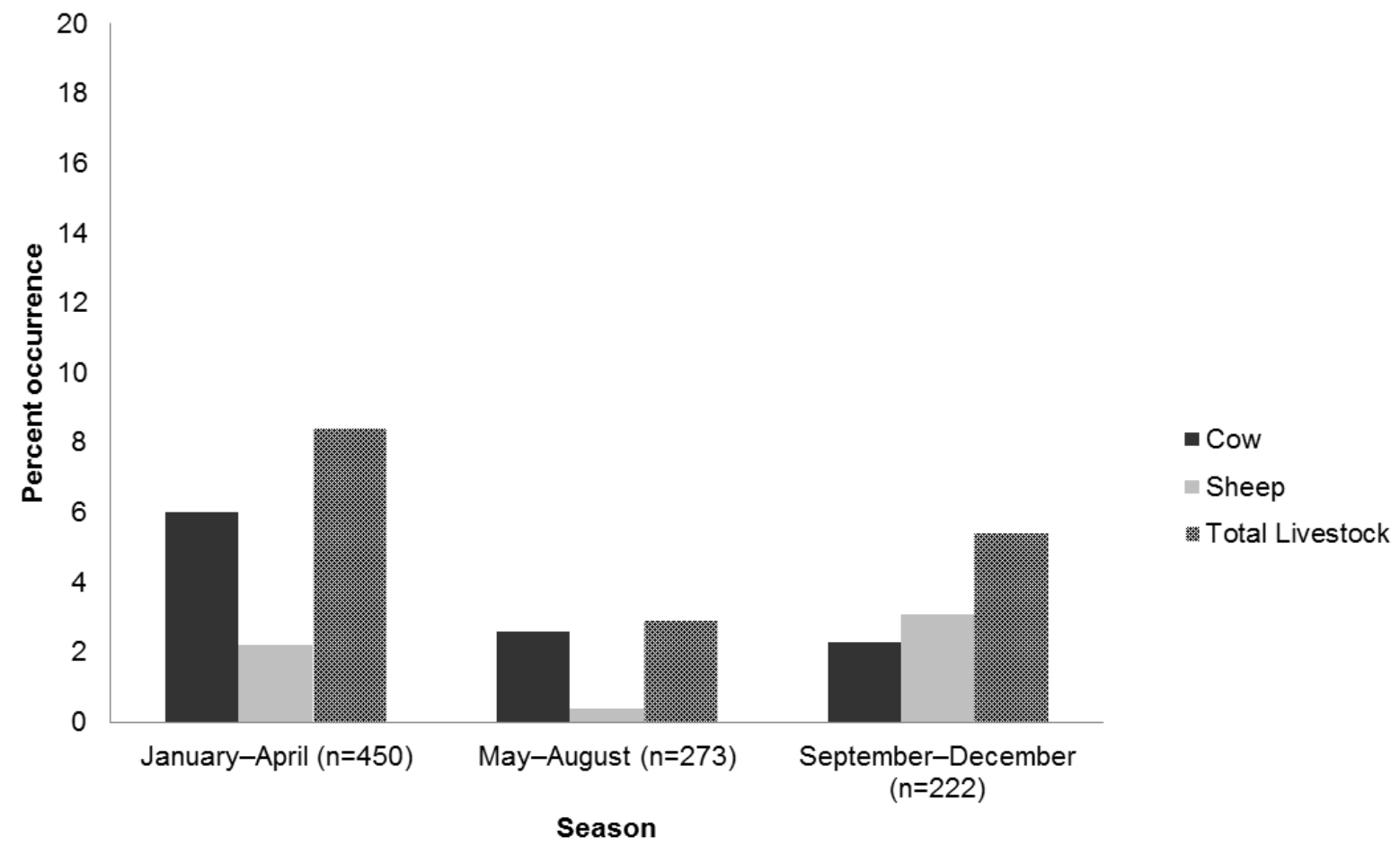




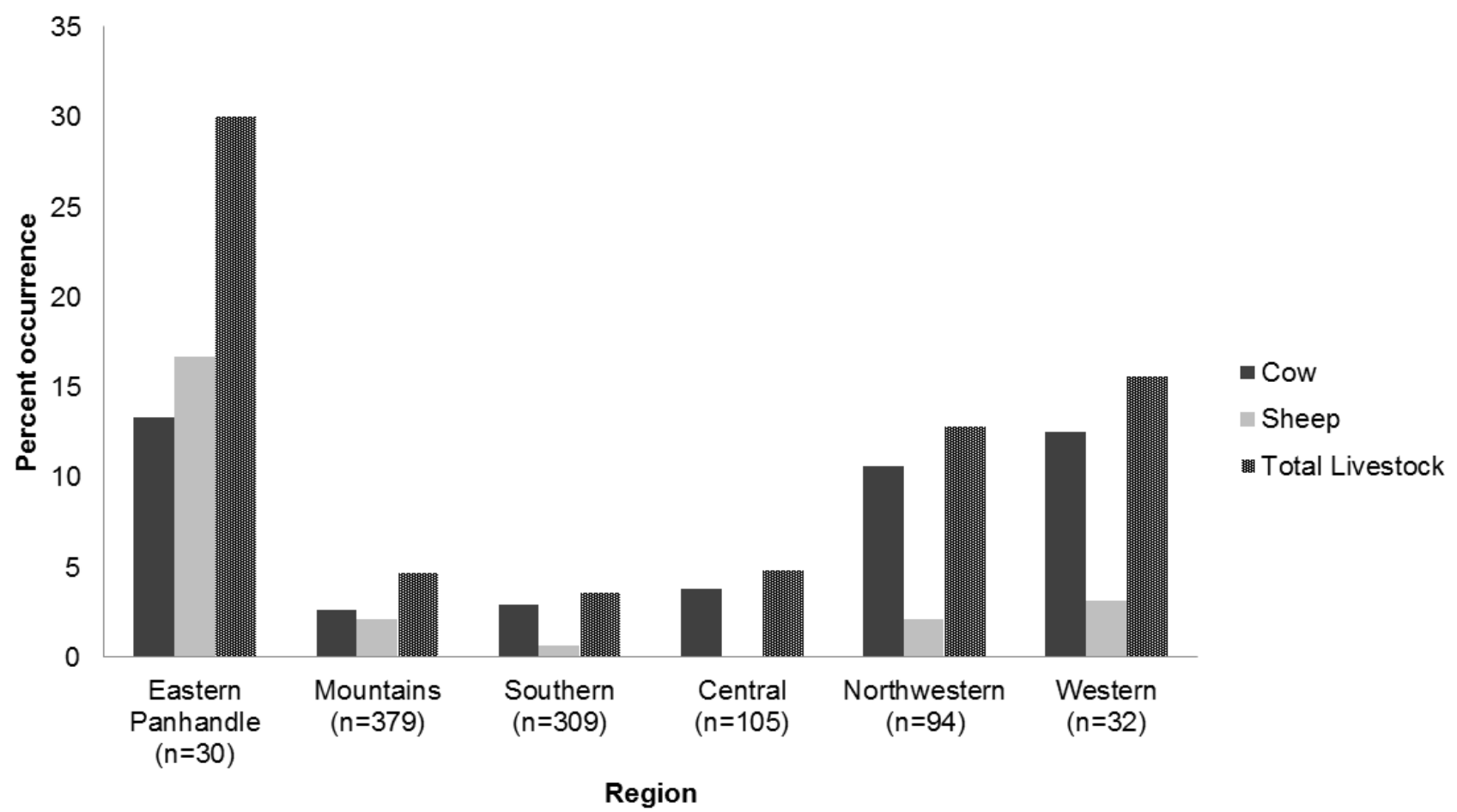




\section{APPENDICES}


Appendix A. All items identified in diets and the aggregate categories we identified in coyote diets in West Virginia November 2009-June 2011.

\begin{tabular}{ll}
\hline Item & Aggregate category \\
\hline Snake skin & Amphibians and reptiles \\
Anurans & \\
Turtle & \\
Beaver (Castor canadensis) & Beaver (Castor canadensis) \\
Turkey & Birds \\
Feathers & \\
Bird parts & \\
Eggshells & Black bear (Ursus americanus) \\
Black bear (Ursus americanus) & Bone \\
Bone & Cat (Felis domesticus) \\
Cat (Felis domesticus) & Coyote (Canis latrans) \\
Coyote (Canis latrans) & Crayfish (Decapoda) \\
Crayfish (Decapoda) & Empty \\
Empty & Fruits and seeds \\
Acorns & Gray fox (Urocyon cinereoargenteus) \\
Black Cherry (Prunus serotina) & \\
Persimmon (Diospyros virginiana) & \\
Fruit flesh & \\
Seeds & \\
Gray fox (Urocyon cinereoargenteus) & \\
\hline
\end{tabular}


Appendix A. Continued

\begin{tabular}{|c|c|}
\hline Item & Aggregate category \\
\hline Coleopterans & Invertebrates \\
\hline \multicolumn{2}{|l|}{ Other Insects } \\
\hline \multicolumn{2}{|l|}{ Other Invertebrates } \\
\hline \multicolumn{2}{|l|}{ Hymenopterans } \\
\hline \multicolumn{2}{|l|}{ Orthopterans } \\
\hline \multicolumn{2}{|l|}{ Unknown Invertebrates } \\
\hline Rabbits and Hares & Lagomorphs \\
\hline Cow & Livestock \\
\hline \multicolumn{2}{|l|}{ Sheep } \\
\hline \multicolumn{2}{|l|}{ Goat } \\
\hline \multicolumn{2}{|l|}{ Horse } \\
\hline Man-made & Man-made materials \\
\hline Mole spp. & Mole spp. \\
\hline Muskrat (Ondatra zibethicus) & Muskrat (Ondatra zibethicus) \\
\hline Opossum (Didelphis virginiana) & Opossum (Didelphis virginiana) \\
\hline Organic material & Organic material \\
\hline Grass & Plant material \\
\hline \multicolumn{2}{|l|}{ Leaves } \\
\hline \multicolumn{2}{|l|}{ Other plant material } \\
\hline Raccoon (Procyon lotor) & Raccoon (Procyon lotor) \\
\hline Red fox (Vulpes vulpes) & Red fox (Vulpes vulpes) \\
\hline Rocks & Rocks \\
\hline Red Squirrel (Tamiasciurus hudsonicus) & Squirrels and chipmunks \\
\hline
\end{tabular}


Appendix A. Continued

Item Aggregate category

Chipmunk (Tamias striatus)

Skunk spp.

Skunk

Miscellaneous small mammals

Small mammals

Sigmodons

Shrews

Vole

Woodrats

Jumping mice

Mus sp.

Peromyscus sp.

Rat species

Unknown

Unknown

Weasel spp.

Weasel spp.

White-tailed deer (Odocoileus virginianus)

White-tailed deer (Odocoileus virginianus)

Worms

Worms 
Appendix B: Percent occurrence of items in coyote scat and stomach samples collected in West Virginia, November 2009-June 2011.

\begin{tabular}{|c|c|c|c|}
\hline Item & Scat $(n=693)$ & Stomach $(n=276)$ & Overall \\
\hline White-tailed deer (Odocoileus virginianus) & 54.8 & 71.4 & 59.5 \\
\hline Plant material & 42.6 & 32.6 & 39.7 \\
\hline Small mammal & 18.8 & 20.1 & 19.3 \\
\hline Fruits and seeds & 19.2 & 8.3 & 16.1 \\
\hline Rocks & 16.7 & 1.4 & 12.4 \\
\hline Squirrels and chipmunks & 13.9 & 5.1 & 11.3 \\
\hline Invertebrates & 0.1 & 1.4 & 6.8 \\
\hline Organic material & 8.7 & 1.1 & 6.5 \\
\hline Livestock & 1.9 & 17.4 & 6.3 \\
\hline $\begin{array}{l}\text { Rabbits (Sylvilagus floridanus and Lepus } \\
\text { americanus) }\end{array}$ & 5.1 & 2.9 & 4.4 \\
\hline Birds & 3.9 & 5.1 & 4.2 \\
\hline Groundhog (Marmota monax) & 3.2 & 1.1 & 2.6 \\
\hline Bone & 2.3 & 3.2 & 2.6 \\
\hline Man-made & 1.4 & 2.5 & 1.8 \\
\hline Raccoon (Procyon lotor) & 0.9 & 2.2 & 1.2 \\
\hline Worms & & 4.3 & 1.2 \\
\hline Beaver (Castor canadensis) & 0.3 & 1.0 & 0.5 \\
\hline Amphibians and reptiles & 0.6 & & 0.4 \\
\hline Weasel spp. (Mustelidae) & 0.4 & 0.4 & 0.4 \\
\hline Black bear (Ursus americanus) & 0.3 & 0.3 & 0.3 \\
\hline Red fox (Vulpes vulpes) & 0.3 & 0.4 & 0.3 \\
\hline Skunk (Mephitis mephitis and Spilogale putoris) & 0.3 & 0.4 & 0.3 \\
\hline
\end{tabular}


Appendix B. Continued

\begin{tabular}{|c|c|c|c|}
\hline Item & Scat $(n=693)$ & Stomach $(n=276)$ & Overall \\
\hline Cat (Felis domesticus) & 0.1 & 0.7 & 0.3 \\
\hline Muskrat (Ondatra zibethicus) & 0.3 & & 0.2 \\
\hline Gray fox (Urocyon cinereoargenteus) & 0.1 & 0.4 & 0.2 \\
\hline Opossum (Didelphis virginiana) & 0.1 & 0.4 & 0.2 \\
\hline Unknown & 0.1 & 2.9 & 0.2 \\
\hline Crayfish (Decapoda) & 0.1 & & 0.1 \\
\hline Mole spp. (Talpidae) & & 0.4 & 0.1 \\
\hline
\end{tabular}


Appendix C. Volume (\%) of diet items from coyotes in West Virginia, November 2009-June 2011.

\begin{tabular}{lcc}
\hline Item & Mean & SE \\
\hline White-tailed deer (Odocoileus virginianus) & 44.9 & 1.38 \\
Small mammals & 12.5 & 0.91 \\
Squirrels and chipmunks & 8.2 & 0.80 \\
Fruits and seeds & 7.1 & 0.67 \\
Plant material & 7.1 & 0.47 \\
Rabbits (Sylvilagus floridanus and Lepus americanus) & 3.3 & 0.53 \\
Livestock & 3.1 & 0.48 \\
Organic material & 2.0 & 0.31 \\
Invertebrates & 1.8 & 0.31 \\
Groundhog (Marmota monax) & 1.7 & 0.37 \\
Rock & 1.1 & 0.13 \\
Raccoon (Procyon lotor) & 0.8 & 0.26 \\
Coyote (Canis latrans) & 0.8 & 0.24 \\
Bone & 0.2 \\
Beaver (Castor canadensis) & 0.3 & 0.10 \\
Man-made & 0.3 & 0.15 \\
Weasel spp. (Mustelidae) & 0.15 \\
Cat (Felis domesticus) & 0.10 \\
Black bear (Ursus americanus) & 0.12 \\
Muskrat (Ondatra zibethicus) & 0.12 \\
Opossum (Didelphis virginiana) & & \\
\hline
\end{tabular}


Appendix C. Continued

\begin{tabular}{lcc}
\hline Item & Mean & SE \\
\hline Skunk (Mephitis mephitis and Spilogale putoris) & 0.1 & 0.11 \\
Worms & 0.1 & 0.04 \\
Unknown & 0.1 & 0.04 \\
Gray fox (Urocyon cinereoargenteus) & 0.1 & 0.10 \\
Mole spp. (Talpidae) & 0.1 & 0.10 \\
Red fox (Vulpes vulpes) & 0.1 & 0.04 \\
Crayfish (Decapoda) & $<0.01$ & $<0.01$ \\
\hline
\end{tabular}


Appendix D: Summary of coyote diet literature in the Eastern United States.

\begin{tabular}{|c|c|c|c|c|c|}
\hline Region & State & Year/Season & $\begin{array}{c}\text { Stomach } \\
(n=)\end{array}$ & $\begin{array}{l}\text { Scat } \\
(n=)\end{array}$ & Reference \\
\hline \multirow[t]{8}{*}{ Midwest } & Illinois & $\begin{array}{l}\text { Winter 1977-1978 } \\
\text { and Winter 1978- } \\
1979\end{array}$ & 125 & & Alesandrini 1983 \\
\hline & Illinois & $\begin{array}{c}\text { April-August 1984- } \\
1986\end{array}$ & & 496 & $\begin{array}{l}\text { Cypher et al. } \\
1993\end{array}$ \\
\hline & Illinois & $\begin{array}{c}\text { May } 2000- \\
\text { December } 2002\end{array}$ & & 1,429 & Morey et al. 2007 \\
\hline & Michigan & $1956-1965$ & & 92 & $\begin{array}{l}\text { Ozoga and } \\
\text { Harger } 1966\end{array}$ \\
\hline & Ohis & July $2002-$ & & 044 & Bollin-Booth \\
\hline & ชกบ & July 2005 & & דודל & 1995 \\
\hline & Ohio & $\begin{array}{l}\text { February } 1998- \\
\text { March } 1999\end{array}$ & & 50 & Cepek 2004 \\
\hline & $\begin{array}{l}\text { Wisconsin and } \\
\text { Minnesota }\end{array}$ & $1969-1982$ & & 10,169 & Smith 1984 \\
\hline \multirow[t]{8}{*}{ Northeast } & Maine & $1979-1983$ & & 2,101 & $\begin{array}{l}\text { Dibello et al. } \\
1990\end{array}$ \\
\hline & Maine & May - October 1981 & & 452 & $\begin{array}{l}\text { Harrison and } \\
\text { Harrison } 1984\end{array}$ \\
\hline & Maine & $1973-1975$ & 112 & 414 & Hilton 1976 \\
\hline & Maine & $\begin{array}{c}\text { January } 1980- \\
\text { October } 1983\end{array}$ & & 1,149 & $\begin{array}{l}\text { Litvaitis and } \\
\text { Harrison } 1988\end{array}$ \\
\hline & Maine & $1979-1982$ & & 531 & $\begin{array}{l}\text { Major and } \\
\text { Sherburne } 1987\end{array}$ \\
\hline & Maine & $1989-1991$ & & 1,741 & $\begin{array}{l}\text { O'Connell et al. } \\
1992\end{array}$ \\
\hline & New Hampshire & $\begin{array}{c}\text { Fall/winter } 1979- \\
1981\end{array}$ & 265 & & $\begin{array}{l}\text { Moore and Millar } \\
1986\end{array}$ \\
\hline & New York & $1975-1980$ & & 1,303 & Chambers 1987 \\
\hline
\end{tabular}


Appendix D. Continued

\begin{tabular}{|c|c|c|c|c|c|}
\hline Region & State & Year/Season & $\begin{array}{l}\text { Stomach } \\
\qquad(n=)\end{array}$ & $\begin{array}{l}\text { Scat } \\
(n=)\end{array}$ & Reference \\
\hline \multirow[t]{4}{*}{ Northeast } & New York & $1956-1961$ & & 1,500 & Hamilton 1974 \\
\hline & Pennsylvania & $1991-1992$ & & 300 & $\begin{array}{l}\text { Witmer et al. } \\
1995\end{array}$ \\
\hline & Vermont & $1984-1986$ & & 306 & Person 1988 \\
\hline & West Virginia & $\begin{array}{l}\text { November } 1998- \\
\text { February } 1999\end{array}$ & 24 & & Wykle 1999 \\
\hline \multirow[t]{12}{*}{ Southeast } & Alabama & $\begin{array}{c}\text { June } 1988- \\
\text { November } 1989\end{array}$ & & 292 & $\begin{array}{l}\text { Hoerath and } \\
\text { Causey } 1991\end{array}$ \\
\hline & Alabama & $\begin{array}{c}\text { July } 2006 \text { - June } \\
2007\end{array}$ & 16 & 150 & VanGlider 2008 \\
\hline & Arkansas & $\begin{array}{c}\text { Winter } 1957-\text { March } \\
1961\end{array}$ & 66 & & Fooks 1961 \\
\hline & Arkansas & $\begin{array}{c}\text { July } 1969 \text { - January } \\
1974\end{array}$ & 168 & & Gipson 1974 \\
\hline & Florida & $\begin{array}{c}\text { May } 2001 \text { - May } \\
2002\end{array}$ & & 86 & $\begin{array}{l}\text { Thornton et al. } \\
2004\end{array}$ \\
\hline & Florida & $\begin{array}{c}\text { May } 2005-\text { March } \\
2007\end{array}$ & & 120 & $\begin{array}{l}\text { Grigione et al. } \\
2011\end{array}$ \\
\hline & Florida & $\begin{array}{l}\text { November } 1994- \\
\text { October } 1996\end{array}$ & & 166 & $\begin{array}{l}\text { Stratman and } \\
\text { Pelton } 1997\end{array}$ \\
\hline & $\begin{array}{l}\text { Florida, Alabama, } \\
\text { Mississippi, } \\
\text { Arkansas }\end{array}$ & $\begin{array}{l}\text { March } 1991 \text { - July } \\
1991 \text { and January - } \\
\text { August } 1992\end{array}$ & & 688 & $\begin{array}{l}\text { Wagner and Hill } \\
1994\end{array}$ \\
\hline & Georgia & $\begin{array}{c}\text { May } 2005 \text { - August } \\
2006\end{array}$ & & 127 & Owens 2006 \\
\hline & Kentucky & $\begin{array}{l}\text { November } 1986- \\
\text { February } 1987\end{array}$ & 66 & & $\begin{array}{l}\text { Crossett and } \\
\text { Elliott } 1991\end{array}$ \\
\hline & Mississippi & March 1991 - 1997 & & 592 & $\begin{array}{l}\text { Chamberlain and } \\
\text { Leopold } 1999\end{array}$ \\
\hline & $\begin{array}{l}\text { Mississippi, } \\
\text { Alabama }\end{array}$ & $\begin{array}{l}\text { December } 1980- \\
\quad \text { April } 1984\end{array}$ & 100 & 211 & $\begin{array}{l}\text { Wooding et al. } \\
1984\end{array}$ \\
\hline
\end{tabular}


Appendix D. Continued

\begin{tabular}{|c|c|c|c|c|c|}
\hline Region & State & Year/Season & $\begin{array}{c}\text { Stomach } \\
(n=)\end{array}$ & $\begin{array}{l}\text { Scat } \\
(n=)\end{array}$ & Reference \\
\hline \multirow[t]{6}{*}{ Southeast } & $\begin{array}{c}\text { Mississippi, } \\
\text { Alabama, } \\
\text { Tennessee, } \\
\text { Kentucky }\end{array}$ & $\begin{array}{c}\text { May } 1985- \\
\text { September } 1986\end{array}$ & 9 & 523 & Blanton 1988 \\
\hline & South Carolina & $\begin{array}{c}\text { May } 2005- \\
\text { July } 2006\end{array}$ & & 415 & $\begin{array}{l}\text { Schrecengost } \\
2007\end{array}$ \\
\hline & Tennessee & $\begin{array}{c}\text { Fall } 1993-\text { Summer } \\
1995\end{array}$ & & 2,004 & Grogan 1996 \\
\hline & Tennessee & $1981-1984$ & 262 & & Lee 1986 \\
\hline & Tennessee & $\begin{array}{l}\text { January } 1997- \\
\text { February } 1998\end{array}$ & & 675 & Parker 1999 \\
\hline & Tennessee & $\begin{array}{c}\text { Fall } 1979 \text { - Summer } \\
1981\end{array}$ & 54 & & $\begin{array}{l}\text { Smith and } \\
\text { Kennedy } 1983\end{array}$ \\
\hline
\end{tabular}


Appendix E. Sample sizes broken down by region in the state of West Virginia, season of the year, and age class and sex of coyote (for stomach samples) for coyote diets in West Virginia during November 2009-June 2011.

\begin{tabular}{|c|c|c|c|c|c|}
\hline Region & Season & Sample type & Age & Sex & $\begin{array}{r}\text { Sample size } \\
(n=)\end{array}$ \\
\hline All & & & & & 969 \\
\hline \multirow[t]{22}{*}{1} & & & & & 30 \\
\hline & 1 & Stomach & & & 24 \\
\hline & & & Adult & & 5 \\
\hline & & & & Male & 3 \\
\hline & & & & Female & 1 \\
\hline & & & Juvenile & & 19 \\
\hline & & & & Male & 10 \\
\hline & & & & Female & 6 \\
\hline & 2 & Stomach & & & 1 \\
\hline & & & Adult & & 1 \\
\hline & & & & Male & 1 \\
\hline & & & & Female & 0 \\
\hline & & & Juvenile & & 0 \\
\hline & & & & Male & 0 \\
\hline & & & & Female & 0 \\
\hline & 3 & Stomach & & & 6 \\
\hline & & & Adult & & 1 \\
\hline & & & & Male & 0 \\
\hline & & & & Female & 1 \\
\hline & & & Juvenile & & 5 \\
\hline & & & & Male & 3 \\
\hline & & & & Female & 0 \\
\hline \multirow[t]{16}{*}{2} & & & & & 380 \\
\hline & 1 & & & & 134 \\
\hline & & Stomach & & & 24 \\
\hline & & & Adult & & 5 \\
\hline & & & & Male & 3 \\
\hline & & & & Female & 2 \\
\hline & & & Juvenile & & 17 \\
\hline & & & & Male & 6 \\
\hline & & & & Female & 10 \\
\hline & & Scat & & & 127 \\
\hline & 2 & & & & 179 \\
\hline & & Stomach & & & 3 \\
\hline & & & Adult & & 2 \\
\hline & & & & Male & 1 \\
\hline & & & & Female & 1 \\
\hline & & & Juvenile & & 1 \\
\hline
\end{tabular}


Appendix E. Continued

\begin{tabular}{|c|c|c|c|c|c|}
\hline Region & Season & Sample type & Age & Sex & $\begin{array}{r}\text { Sample size } \\
(n=)\end{array}$ \\
\hline & & & & Female & 0 \\
\hline & & & Unknown & Male & 1 \\
\hline & & Scat & & & 175 \\
\hline & 3 & & & & 67 \\
\hline & & Stomach & & & 12 \\
\hline & & & Adult & & 5 \\
\hline & & & & Male & 2 \\
\hline & & & & Female & 3 \\
\hline & & & Juvenile & & 5 \\
\hline & & & & Male & 0 \\
\hline & & & & Female & 3 \\
\hline & & & Unknown & Female & 1 \\
\hline & & Scat & & & 55 \\
\hline 3 & & & & & 310 \\
\hline & 1 & & & & 102 \\
\hline & & Stomach & & & 13 \\
\hline & & & Adult & & 3 \\
\hline & & & & Male & 0 \\
\hline & & & & Female & 3 \\
\hline & & & Juvenile & & 9 \\
\hline & & & & Male & 1 \\
\hline & & & & Female & 7 \\
\hline & & & Unknown & Male & 1 \\
\hline & & Scat & & & 89 \\
\hline & 2 & & & & 71 \\
\hline & & Stomach & & & 2 \\
\hline & & & Adult & & 0 \\
\hline & & & & Male & 0 \\
\hline & & & & Female & 0 \\
\hline & & & Juvenile & & 1 \\
\hline & & & & Male & 1 \\
\hline & & & & Female & 0 \\
\hline & & Scat & & & 69 \\
\hline & 3 & & & & 132 \\
\hline & & Stomach & & & 6 \\
\hline & & & Adult & & 2 \\
\hline & & & & Male & 1 \\
\hline & & & & Female & 1 \\
\hline & & & Juvenile & & 4 \\
\hline & & & & Male & 1 \\
\hline & & & & Female & 2 \\
\hline & & Scat & & & 126 \\
\hline & Unknown & Stomach & Adult & Female & 1 \\
\hline
\end{tabular}


Appendix E. Continued

\begin{tabular}{|c|c|c|c|c|c|}
\hline Region & Season & Sample type & Age & Sex & $\begin{array}{r}\text { Sample size } \\
(n=)\end{array}$ \\
\hline & & & Unknown & Male & 1 \\
\hline & & & Unknown & Female & 1 \\
\hline & & Scat & & & 1 \\
\hline \multirow[t]{34}{*}{4} & & & & & 106 \\
\hline & 1 & & & & 79 \\
\hline & & Stomach & & & 37 \\
\hline & & & Adult & & 10 \\
\hline & & & & Male & 6 \\
\hline & & & & Female & 4 \\
\hline & & & Juvenile & & 25 \\
\hline & & & & Male & 9 \\
\hline & & & & Female & 16 \\
\hline & & & Unknown & Female & 1 \\
\hline & & Scat & & & 42 \\
\hline & 2 & & & & 15 \\
\hline & & Stomach & & & 1 \\
\hline & & & Adult & & 0 \\
\hline & & & & Male & 0 \\
\hline & & & & Female & 0 \\
\hline & & & Juvenile & & 1 \\
\hline & & & & Male & 1 \\
\hline & & & & Female & 0 \\
\hline & & Scat & & & 14 \\
\hline & 3 & & & & 7 \\
\hline & & Stomach & & & 5 \\
\hline & & & Adult & & 1 \\
\hline & & & & Male & 1 \\
\hline & & & & Female & 0 \\
\hline & & & Unknown & Female & 2 \\
\hline & & & Juvenile & & 1 \\
\hline & & & & Male & 1 \\
\hline & & & & Female & 0 \\
\hline & & Scat & & & 2 \\
\hline & Unknown & Stomach & Adult & Unknown & 1 \\
\hline & & & Juvenile & Female & 2 \\
\hline & & & Unknown & Male & 1 \\
\hline & & & & Female & 1 \\
\hline \multirow[t]{6}{*}{5} & & & & & 95 \\
\hline & 1 & & & & 82 \\
\hline & & Stomach & & & 73 \\
\hline & & & Adult & & 17 \\
\hline & & & & Male & 8 \\
\hline & & & & Female & 9 \\
\hline
\end{tabular}


Appendix E. Continued

\begin{tabular}{|c|c|c|c|c|c|}
\hline Region & Season & Sample type & Age & Sex & $\begin{array}{r}\text { Sample size } \\
(n=))\end{array}$ \\
\hline & & & Juvenile & & 50 \\
\hline & & & & Male & 23 \\
\hline & & & & Female & 27 \\
\hline & & & Unknown & Male & 1 \\
\hline & & & & Female & 2 \\
\hline & & Scat & & & 9 \\
\hline & 2 & & & & 8 \\
\hline & & Stomach & & & 7 \\
\hline & & & Adult & & 7 \\
\hline & & & & Male & 2 \\
\hline & & & & Female & 4 \\
\hline & & & Juvenile & & 0 \\
\hline & & & & Male & 0 \\
\hline & & & & Female & 0 \\
\hline & & Scat & & & 1 \\
\hline & 3 & & & & 4 \\
\hline & & Stomach & & & 4 \\
\hline & & & Adult & & 3 \\
\hline & & & & Male & 2 \\
\hline & & & & Female & 1 \\
\hline & & & Juvenile & & 1 \\
\hline & & & & Male & 0 \\
\hline & & & & Female & 0 \\
\hline & & Scat & & & 0 \\
\hline & Unknown & Stomach & Juvenile & Male & 1 \\
\hline \multirow[t]{18}{*}{6} & & & & & 33 \\
\hline & 1 & & & & 26 \\
\hline & & Stomach & & & 26 \\
\hline & & & Adult & & 5 \\
\hline & & & & Male & 1 \\
\hline & & & & Female & 3 \\
\hline & & & Juvenile & & 0 \\
\hline & & & & Male & 0 \\
\hline & & & & Female & 0 \\
\hline & & & Unknown & Male & 3 \\
\hline & & & & Female & 4 \\
\hline & & Scat & & & 0 \\
\hline & 2 & & & & 1 \\
\hline & & Stomach & & & 1 \\
\hline & & & Adult & & 0 \\
\hline & & & & Male & 0 \\
\hline & & & & Female & 0 \\
\hline & & & Juvenile & & 1 \\
\hline
\end{tabular}


Appendix E. Continued

\begin{tabular}{|c|c|c|c|c|c|}
\hline \multirow[t]{17}{*}{ Region } & Season & Sample type & Age & Sex & $\begin{array}{r}\text { Sample size } \\
(n=)\end{array}$ \\
\hline & & & & Male & 0 \\
\hline & & & & Female & 0 \\
\hline & & Scat & & & 0 \\
\hline & 3 & & & & 4 \\
\hline & & Stomach & & & 4 \\
\hline & & & Adult & & 2 \\
\hline & & & & Male & 1 \\
\hline & & & & Female & 1 \\
\hline & & & Juvenile & & 2 \\
\hline & & & & Male & 0 \\
\hline & & & & Female & 2 \\
\hline & & Scat & & & 0 \\
\hline & Unknown & & & & 2 \\
\hline & & Stomach & & & 2 \\
\hline & & & Adult & Male & 1 \\
\hline & & & Juvenile & Unknown & 1 \\
\hline \multirow[t]{15}{*}{ Unknown } & & & & & 14 \\
\hline & 1 & & & & 4 \\
\hline & & Stomach & Juvenile & Male & 1 \\
\hline & & & & Unknown & 1 \\
\hline & & & Unknown & Female & 1 \\
\hline & & & & Unknown & 1 \\
\hline & 3 & & & & 3 \\
\hline & & Stomach & Adult & & 1 \\
\hline & & & Juvenile & Female & 1 \\
\hline & & & Unknown & Female & 1 \\
\hline & Unknown & Stomach & Adult & Male & 2 \\
\hline & & & & Female & 0 \\
\hline & & & Juvenile & Male & 3 \\
\hline & & & & Female & 1 \\
\hline & & & Unknown & Female & 1 \\
\hline
\end{tabular}


Appendix F. Age data for all coyotes collected as part of the West Virginia coyote diet study from November 2009-June 2011 based upon lower canine teeth sent to Matson's Laboratory (Milltown, MT). Some teeth were xrayed to look for root tip closure (indicating the animal is a juvenile) before being sent to Matson's, so an additional 30 coyotes that were deemed juveniles based upon root tip closure are not included in this list.

\begin{tabular}{|c|c|c|c|c|c|c|}
\hline Date & Serial & Tooth ID & Age & Confidence & Age range & Aging notes \\
\hline $12 / 18 / 2009$ & 1 & C0001CWS & 1 & A & & \\
\hline $12 / 31 / 2009$ & 1 & C0002CFT & 4 & B & $3-4$ & \\
\hline $12 / 19 / 2009$ & 2 & C0003CWS & 3 & B & $2-3$ & \\
\hline $12 / 21 / 2010$ & 3 & C0004CWS & 0 & A & & \\
\hline $1 / 1 / 2010$ & 2 & C0005CFT & 2 & A & & \\
\hline 9/19/2010 & 4 & C0006CWS & 2 & A & & \\
\hline 1/19/2010 & 5 & C0009CWS & 6 & A & & \\
\hline $1 / 20 / 2010$ & 6 & C0010CWS & 0 & A & & \\
\hline 1/19/2010 & 3 & C0011CWS & 1 & A & & \\
\hline $1 / 20 / 2010$ & 7 & C0012CWS & 3 & A & & \\
\hline 1/20/2010 & 8 & C0013CWS & 1 & A & & \\
\hline 1/30/2010 & 9 & C0014CFT & 4 & A & & \\
\hline 1/30/2010 & 10 & C0015CFT & 0 & A & & \\
\hline 1/30/2010 & 11 & C0016CFT & 0 & A & & \\
\hline 1/30/2010 & 4 & C0018CFT & 1 & A & & \\
\hline $11 / 11 / 2009$ & 12 & C0019HFT & 1 & A & & \\
\hline $11 / 26 / 2009$ & 5 & C0021HFT & 0 & A & & \\
\hline $12 / 5 / 2009$ & 6 & C0023HFT & 1 & A & & \\
\hline $1 / 4 / 2010$ & 13 & C0025HFT & 1 & A & & \\
\hline
\end{tabular}


Appendix F. Continued

\begin{tabular}{|c|c|c|c|c|c|c|}
\hline Date & Serial & Tooth ID & Age & Confidence & Age range & Aging notes \\
\hline $1 / 26 / 2010$ & 14 & C0026CWS & 0 & $\mathrm{~A}$ & & \\
\hline $1 / 25 / 2010$ & 15 & C0028CWS & 0 & A & & \\
\hline $1 / 20 / 2010$ & 16 & C0029HWS & 0 & A & & \\
\hline $2 / 4 / 2010$ & 17 & C0030CWS & 0 & A & & \\
\hline $2 / 2 / 2010$ & 18 & C0031CWS & 0 & A & & \\
\hline $1 / 26 / 2010$ & 19 & C0032CWS & 0 & A & & \\
\hline $1 / 1 / 2010$ & 20 & C0033CWS & 1 & A & & \\
\hline $1 / 29 / 2010$ & 21 & C0034CWS & 0 & A & & \\
\hline $1 / 28 / 2010$ & 22 & C0035HWS & 0 & A & & \\
\hline $2 / 2 / 2010$ & 23 & C0036CWS & 1 & A & & \\
\hline $1 / 6 / 2010$ & 24 & C0037CWS & 1 & A & & \\
\hline $1 / 25 / 2010$ & 7 & C0038CWS & 1 & A & & \\
\hline $2 / 3 / 2010$ & 25 & C0039CFT & 0 & A & & \\
\hline $1 / 1 / 2010$ & 26 & C0040CWS & 0 & A & & \\
\hline $2 / 15 / 2010$ & 27 & C0041CWS & 2 & A & & \\
\hline $1 / 26 / 2010$ & 28 & C0042HWS & 0 & A & & \\
\hline $1 / 21 / 2010$ & 29 & C0043HWS & 1 & A & & \\
\hline $1 / 26 / 2010$ & 30 & C0044HWS & 3 & B & $2-3$ & \\
\hline $2 / 1 / 2010$ & 31 & C0046CWS & 0 & A & & \\
\hline $1 / 27 / 2010$ & 8 & C0049CWS & 3 & A & & \\
\hline $1 / 4 / 2010$ & 9 & C0050CWS & 0 & A & & \\
\hline $2 / 10 / 2010$ & 32 & C0051CWS & 0 & A & & \\
\hline
\end{tabular}


Appendix F. Continued

\begin{tabular}{|c|c|c|c|c|c|c|}
\hline Date & Serial & Tooth ID & Age & Confidence & Age range & Aging notes \\
\hline $2 / 10 / 2010$ & 33 & C0053CWS & 1 & A & & \\
\hline $1 / 1 / 2010$ & 10 & C0055CFT & 11 & A & & \\
\hline $2 / 9 / 2010$ & 11 & C0056CWS & 0 & A & & \\
\hline $2 / 4 / 2010$ & 12 & C0058CWS & 1 & A & & \\
\hline $2 / 8 / 2010$ & 13 & C0059CWS & 1 & A & & \\
\hline $1 / 4 / 2010$ & 34 & C0061CWS & 0 & A & & \\
\hline $1 / 25 / 2010$ & 35 & C0062CWS & 0 & A & & \\
\hline $2 / 10 / 2010$ & 14 & C0065CWS & 0 & A & & \\
\hline $2 / 24 / 2010$ & 15 & C0069CWS & 1 & A & & \\
\hline $2 / 18 / 2010$ & 36 & C0074CWS & 1 & A & & \\
\hline $2 / 3 / 2010$ & 37 & C0075CWS & 1 & A & & \\
\hline $2 / 4 / 2010$ & 38 & C0076CWS & 0 & A & & \\
\hline $2 / 16 / 2010$ & 16 & C0077CWS & 2 & A & & \\
\hline $2 / 4 / 2010$ & 17 & C0078CWS & 3 & A & & \\
\hline $1 / 23 / 2010$ & 39 & C0079CWS & 1 & A & & \\
\hline $1 / 24 / 2010$ & 40 & C0080CWS & 0 & A & & \\
\hline $3 / 1 / 2010$ & 18 & C0083CWS & 1 & A & & \\
\hline $3 / 9 / 2010$ & 41 & C0084CWS & 0 & A & & \\
\hline $3 / 3 / 2010$ & 42 & C0085CWS & 0 & A & & \\
\hline $3 / 9 / 2010$ & 43 & C0086CWS & 2 & A & & \\
\hline $2 / 11 / 2010$ & 44 & C0087CWS & 0 & A & & \\
\hline $3 / 1 / 2010$ & 45 & C0088CWS & 1 & A & & \\
\hline
\end{tabular}


Appendix F. Continued

\begin{tabular}{|c|c|c|c|c|c|c|}
\hline Date & Serial & Tooth ID & Age & Confidence & Age range & Aging notes \\
\hline $3 / 10 / 2010$ & 46 & C0089CWS & 2 & A & & \\
\hline $3 / 3 / 2010$ & 47 & C0092CWS & 0 & A & & \\
\hline $3 / 5 / 2010$ & 48 & C0093CWS & 0 & A & & \\
\hline $3 / 5 / 2010$ & 49 & C0094CWS & 0 & A & & \\
\hline $3 / 5 / 2010$ & 19 & C0095CWS & 0 & A & & \\
\hline $3 / 5 / 2010$ & 50 & C0096CWS & 0 & A & & \\
\hline $3 / 2 / 2010$ & 20 & C0098CWS & 2 & A & & \\
\hline $3 / 10 / 2010$ & 51 & C0100CWS & 0 & A & & \\
\hline $3 / 10 / 2010$ & 52 & C0101CWS & 0 & A & & \\
\hline $3 / 23 / 2010$ & 21 & C0104CWS & 1 & A & & \\
\hline $3 / 22 / 2010$ & 53 & C0105CWS & 0 & A & & \\
\hline $3 / 10 / 2010$ & 22 & C0106CWS & 0 & A & & \\
\hline $3 / 17 / 2010$ & 23 & C0108CWS & 1 & B & $0-1$ & \\
\hline $3 / 16 / 2010$ & 54 & C0109CWS & 0 & A & & \\
\hline $3 / 16 / 2010$ & 55 & C0110CWS & 0 & A & & \\
\hline $3 / 17 / 2010$ & 24 & C0111CWS & 0 & A & & \\
\hline $3 / 18 / 2010$ & 25 & C0112CWS & 0 & A & & \\
\hline $3 / 16 / 2010$ & 26 & C0113CWS & 0 & A & & \\
\hline $3 / 15 / 2010$ & 27 & C0114CWS & 0 & A & & \\
\hline $3 / 15 / 2010$ & 28 & C0116CWS & 0 & A & & \\
\hline $3 / 17 / 2010$ & 29 & C0120CWS & 0 & A & & \\
\hline $3 / 5 / 2010$ & 30 & C0121CWS & 0 & A & & \\
\hline
\end{tabular}


Appendix F. Continued

\begin{tabular}{|c|c|c|c|c|c|c|}
\hline Date & Serial & Tooth ID & Age & Confidence & Age range & Aging notes \\
\hline $3 / 18 / 2010$ & 56 & C0122CWS & 0 & $\mathrm{~A}$ & & \\
\hline $3 / 9 / 2010$ & 31 & C0123CWS & 1 & A & & \\
\hline $3 / 18 / 2010$ & 32 & C0124CWS & 0 & A & & \\
\hline $3 / 21 / 2010$ & 57 & C0125CWS & 1 & A & & \\
\hline $3 / 24 / 2010$ & 33 & C0126CWS & 1 & A & & \\
\hline $3 / 29 / 2010$ & 58 & C0127CWS & 0 & A & & \\
\hline $3 / 29 / 2010$ & 34 & C0128CWS & 0 & A & & \\
\hline $3 / 24 / 2010$ & 35 & C0129CWS & 0 & A & & \\
\hline $3 / 31 / 2010$ & 59 & C0130CWS & 1 & A & & \\
\hline $3 / 24 / 2010$ & 36 & C0131CWS & 1 & A & & \\
\hline $3 / 18 / 2010$ & 60 & C0133CWS & 1 & A & & \\
\hline $3 / 9 / 2010$ & 37 & C0134CWS & 1 & A & & \\
\hline $3 / 9 / 2010$ & 61 & C0136CWS & 0 & A & & \\
\hline $3 / 17 / 2010$ & 62 & C0137CWS & 0 & A & & \\
\hline $3 / 12 / 2010$ & 38 & C0138CWS & 4 & A & & \\
\hline $3 / 2 / 2010$ & 39 & C0139CWS & 2 & A & & \\
\hline $3 / 17 / 2010$ & 40 & C0140CWS & 0 & A & & \\
\hline $3 / 17 / 2010$ & 63 & C0141CWS & 0 & A & & \\
\hline $3 / 10 / 2010$ & 41 & C0142CWS & 4 & B & $4-5$ & \\
\hline $1 / 20 / 2010$ & 64 & C0143CWS & 0 & A & & \\
\hline $4 / 2 / 2010$ & 42 & C0144CWS & 1 & A & & \\
\hline $4 / 12 / 2010$ & 65 & C0145CWS & 0 & A & & \\
\hline
\end{tabular}


Appendix F. Continued

\begin{tabular}{|c|c|c|c|c|c|c|}
\hline Date & Serial & Tooth ID & Age & Confidence & Age range & Aging notes \\
\hline $3 / 2 / 2010$ & 66 & C0146CWS & 0 & $\mathrm{~A}$ & & \\
\hline $4 / 7 / 2010$ & 67 & C0147CWS & 0 & A & & \\
\hline $4 / 13 / 2010$ & 68 & C0148CWS & 0 & A & & \\
\hline $4 / 17 / 2010$ & 69 & C0149CWS & 0 & A & & \\
\hline $3 / 18 / 2010$ & 43 & C0150CWS & 4 & A & & \\
\hline $3 / 22 / 2010$ & 44 & C0151CWS & 1 & A & & \\
\hline $4 / 12 / 2010$ & 70 & C0152CWS & 3 & A & & \\
\hline $4 / 23 / 2010$ & 71 & C0153CWS & 0 & A & & \\
\hline $4 / 13 / 2010$ & 72 & C0155CWS & 1 & A & & \\
\hline $4 / 30 / 2010$ & 73 & C0156CWS & 1 & A & & \\
\hline $3 / 9 / 2010$ & 74 & C0157CWS & 1 & A & & \\
\hline $4 / 23 / 2010$ & 75 & C0158CWS & 0 & A & & \\
\hline $3 / 15 / 2010$ & 76 & C0159CWS & 0 & A & & \\
\hline $5 / 17 / 2010$ & 77 & C0160CWS & 1 & A & & \\
\hline $4 / 18 / 2010$ & 45 & C0161CWS & 0 & A & & \\
\hline $4 / 17 / 2010$ & 78 & C0162CWS & 0 & A & & \\
\hline $3 / 16 / 2010$ & 79 & C0163CWS & 1 & A & & \\
\hline $1 / 1 / 2010$ & 46 & C0165HFT & 2 & A & & \\
\hline $1 / 1 / 2010$ & 47 & C0166HFT & 3 & A & & \\
\hline $3 / 16 / 2010$ & 80 & C0168CWS & 1 & A & & \\
\hline $3 / 16 / 2010$ & 81 & C0169CWS & 3 & B & $2-3$ & \\
\hline $8 / 7 / 2010$ & 48 & C0171CWS & 6 & A & & \\
\hline
\end{tabular}


Appendix F. Continued

\begin{tabular}{|c|c|c|c|c|c|c|}
\hline Date & Serial & Tooth ID & Age & Confidence & Age range & Aging notes \\
\hline $7 / 11 / 2010$ & 49 & C0172CWS & 1 & $\mathrm{~A}$ & & \\
\hline $8 / 7 / 2010$ & 50 & C0173CWS & 1 & A & & \\
\hline $5 / 7 / 2010$ & 51 & C0174CWS & 1 & A & & \\
\hline $7 / 9 / 2010$ & 52 & C0175CWS & 5 & A & & \\
\hline $7 / 14 / 2010$ & 53 & C0176CWS & 1 & A & & \\
\hline $5 / 18 / 2010$ & 54 & C0177CWS & 2 & A & & \\
\hline $7 / 9 / 2010$ & 55 & C0178CWS & 7 & A & & \\
\hline $1 / 1 / 2010$ & 56 & C0179CWS & 3 & A & & \\
\hline $9 / 1 / 2010$ & 187 & C0181CWS & 1 & A & & \\
\hline $1 / 1 / 2010$ & 57 & C0182CWS & 0 & A & & \\
\hline 7/19/2010 & 58 & C0183CWS & 1 & A & & \\
\hline $9 / 1 / 2010$ & 188 & C0184CWS & 5 & A & & \\
\hline $8 / 16 / 2010$ & 59 & C0186CWS & 3 & A & & \\
\hline $4 / 6 / 2010$ & 60 & C0189CWS & 0 & A & & \\
\hline $9 / 1 / 2010$ & 61 & C0239CWS & 1 & A & & \\
\hline $9 / 21 / 2010$ & 62 & C0241CWS & 1 & A & & \\
\hline $9 / 20 / 2010$ & 63 & C0242CWS & 1 & A & & \\
\hline $9 / 14 / 2010$ & 64 & C0243CWS & 1 & A & & \\
\hline $10 / 19 / 2010$ & 65 & C0244CWS & 3 & A & & \\
\hline $9 / 12 / 2010$ & 66 & C0245CWS & 1 & A & & \\
\hline $9 / 3 / 2010$ & 67 & C0246CWS & 2 & A & & \\
\hline 8/17/2010 & 68 & C0247CWS & 1 & A & & \\
\hline
\end{tabular}


Appendix F. Continued

\begin{tabular}{|c|c|c|c|c|c|c|}
\hline Date & Serial & Tooth ID & Age & Confidence & Age range & Aging notes \\
\hline $9 / 1 / 2010$ & 69 & C0248CWS & 0 & $\mathrm{~A}$ & & \\
\hline $9 / 2 / 2010$ & 70 & C0249CWS & 1 & A & & \\
\hline $9 / 10 / 2010$ & 71 & C0250CWS & 2 & B & $1-2$ & \\
\hline $11 / 18 / 2010$ & 72 & C0271CFT & 0 & A & & IN \\
\hline $11 / 15 / 2010$ & 73 & C0272CFT & 1 & A & & \\
\hline $9 / 23 / 2010$ & 74 & C0273CWS & 1 & A & & \\
\hline $11 / 8 / 2010$ & 75 & C0274CFT & 1 & A & & \\
\hline $11 / 11 / 2010$ & 76 & C0276CFT & 0 & A & & \\
\hline $2 / 24 / 2010$ & 77 & C0277CWS & 4 & A & & \\
\hline $11 / 10 / 2010$ & 78 & C0278CWS & 4 & A & & \\
\hline $9 / 25 / 2010$ & 79 & C0280CFT & 2 & A & & \\
\hline $3 / 9 / 2010$ & 80 & C0282CWS & 1 & A & & \\
\hline $9 / 1 / 2010$ & 184 & C0301CWS & 0 & A & & \\
\hline $9 / 1 / 2010$ & 185 & C0302CWS & 6 & A & & \\
\hline $9 / 1 / 2010$ & 186 & C0305CWS & 0 & A & & \\
\hline $10 / 27 / 2010$ & 81 & C0306CWS & 3 & A & & \\
\hline $11 / 10 / 2010$ & 82 & C0308CWS & 1 & A & & \\
\hline $9 / 3 / 2010$ & 83 & C0309CWS & 0 & A & & IN \\
\hline $12 / 27 / 2010$ & 84 & C0349HFT & 1 & A & & \\
\hline $11 / 25 / 2010$ & 85 & C0350HFT & 0 & A & & \\
\hline $10 / 11 / 2010$ & 86 & C0354COT & 1 & A & & \\
\hline fall 2010 & 87 & C0355COT & 1 & A & & \\
\hline
\end{tabular}


Appendix F. Continued

\begin{tabular}{|c|c|c|c|c|c|c|}
\hline Date & Serial & Tooth ID & Age & Confidence & Age range & Aging notes \\
\hline $11 / 29 / 2010$ & 88 & C0356COT & 1 & $\mathrm{~A}$ & & \\
\hline $1 / 13 / 2011$ & 89 & C0385CWS & 2 & A & & \\
\hline $1 / 12 / 2011$ & 90 & C0386CWS & 0 & A & & \\
\hline $1 / 9 / 2011$ & 91 & C0389CWS & 0 & A & & \\
\hline $1 / 12 / 2011$ & 92 & C0423CWS & 1 & A & & \\
\hline $1 / 10 / 2011$ & 93 & C0424CWS & 1 & A & & \\
\hline $1 / 11 / 2011$ & 94 & C0425CWS & 0 & A & & \\
\hline $12 / 7 / 2010$ & 95 & C0429CWS & 0 & A & & \\
\hline $1 / 18 / 2011$ & 96 & C0441CWS & 1 & A & & \\
\hline $1 / 11 / 2011$ & 97 & C0442CWS & 2 & A & & \\
\hline $1 / 10 / 2011$ & 98 & C0444CWS & 1 & A & & \\
\hline $9 / 24 / 2010$ & 99 & C0445CWS & 0 & A & & \\
\hline $3 / 23 / 2010$ & 100 & C0465HFT & 0 & A & & \\
\hline $1 / 31 / 2011$ & 101 & C0492CWS & 0 & A & & \\
\hline $1 / 19 / 2011$ & 102 & C0496CWS & 0 & A & & \\
\hline $2 / 1 / 2011$ & 103 & C0497CWS & 0 & A & & \\
\hline $1 / 31 / 2011$ & 104 & C0504CWS & 0 & A & & \\
\hline $1 / 31 / 2011$ & 105 & C0505CWS & 0 & A & & \\
\hline $2 / 3 / 2011$ & 106 & C0507CWS & 0 & A & & \\
\hline $2 / 2 / 2011$ & 107 & C0508CWS & 0 & A & & \\
\hline $1 / 1 / 2011$ & 108 & C0521CFT & 0 & A & & \\
\hline $2 / 4 / 2011$ & 109 & C0526CWS & 0 & A & & \\
\hline
\end{tabular}


Appendix F. Continued

\begin{tabular}{|c|c|c|c|c|c|c|}
\hline Date & Serial & Tooth ID & Age & Confidence & Age range & Aging notes \\
\hline $2 / 4 / 2011$ & 110 & C0528CWS & 0 & $\mathrm{~A}$ & & \\
\hline $1 / 26 / 2011$ & 111 & C0529CWS & 0 & A & & \\
\hline $1 / 26 / 2011$ & 112 & C0531CWS & 0 & A & & \\
\hline 2/7/2011 & 113 & C0535CWS & 1 & A & & \\
\hline 2/4/2011 & 114 & C0536CWS & 4 & A & & \\
\hline $2 / 7 / 2011$ & 115 & C0537CWS & 0 & A & & \\
\hline 2/8/2011 & 116 & C0540CWS & 0 & A & & \\
\hline $2 / 7 / 2011$ & 117 & C0543CWS & 0 & A & & \\
\hline $2 / 14 / 2011$ & 118 & C0547CWS & 0 & A & & \\
\hline $2 / 10 / 2011$ & 119 & C0548CWS & 2 & A & & \\
\hline $2 / 10 / 2011$ & 120 & C0549CWS & 0 & A & & \\
\hline 2/7/2011 & 121 & C0551CWS & 0 & A & & \\
\hline $2 / 7 / 2011$ & 122 & C0552CWS & 0 & B & $0-1$ & \\
\hline 2/9/2011 & 123 & C0554CWS & 1 & A & & \\
\hline $2 / 7 / 2011$ & 124 & C0555CWS & 1 & A & & \\
\hline $2 / 15 / 2011$ & 125 & C0556CWS & 1 & A & & \\
\hline $2 / 14 / 2011$ & 126 & C0559CWS & 0 & A & & \\
\hline $2 / 14 / 2011$ & 127 & C0560CWS & 1 & A & & \\
\hline $2 / 15 / 2011$ & 128 & C0561CWS & 0 & B & $0-1$ & \\
\hline $2 / 14 / 2011$ & 129 & C0562CWS & 0 & A & & \\
\hline $2 / 8 / 2011$ & 130 & C0568HWS & 0 & A & & \\
\hline $2 / 3 / 2011$ & 131 & C0569CWS & 0 & A & & \\
\hline
\end{tabular}


Appendix F. Continued

\begin{tabular}{|c|c|c|c|c|c|c|}
\hline Date & Serial & Tooth ID & Age & Confidence & Age range & Aging notes \\
\hline $2 / 11 / 2011$ & 132 & C0570CWS & 1 & $\mathrm{~A}$ & & \\
\hline $2 / 22 / 2011$ & 133 & C0571CWS & 1 & B & $1-2$ & \\
\hline $2 / 23 / 2011$ & 134 & C0572CWS & 0 & A & & \\
\hline 2/23/2011 & 135 & C0573CWS & 0 & A & & \\
\hline $2 / 4 / 2011$ & 136 & C0574CWS & 0 & A & & \\
\hline $2 / 22 / 2011$ & 137 & C0576CWS & 1 & A & & \\
\hline 2/23/2011 & 138 & C0577CWS & 4 & A & & \\
\hline $2 / 22 / 2011$ & 139 & C0580CFT & 0 & A & & \\
\hline $1 / 1 / 2011$ & 140 & C0583CFT & 0 & A & & \\
\hline $1 / 1 / 2011$ & 141 & C0585CFT & 0 & A & & \\
\hline $11 / 16 / 2010$ & 142 & C0587CWS & 0 & A & & \\
\hline $2 / 23 / 2011$ & 143 & C0589CWS & 0 & A & & \\
\hline 2/23/2011 & 144 & C0590CWS & 0 & A & & \\
\hline $2 / 23 / 2011$ & 145 & C0591CWS & 0 & A & & \\
\hline $2 / 17 / 2011$ & 146 & C0592CWS & 0 & A & & \\
\hline $2 / 23 / 2011$ & 147 & C0594CWS & 0 & A & & \\
\hline $2 / 23 / 2011$ & 148 & C0595CWS & 1 & A & & \\
\hline $3 / 4 / 2011$ & 149 & C0596CWS & 0 & A & & \\
\hline $2 / 24 / 2011$ & 150 & C0597CWS & 8 & A & & \\
\hline $3 / 2 / 2011$ & 151 & C0598CWS & 1 & A & & \\
\hline $3 / 2 / 2011$ & 152 & C0599CWS & 0 & A & & \\
\hline $3 / 4 / 2011$ & 153 & C0600CWS & 0 & B & $0-1$ & \\
\hline
\end{tabular}


Appendix F. Continued

\begin{tabular}{|c|c|c|c|c|c|c|}
\hline Date & Serial & Tooth ID & Age & Confidence & Age range & Aging notes \\
\hline $2 / 28 / 2011$ & 154 & C0601CWS & 1 & $\mathrm{~A}$ & & \\
\hline $3 / 2 / 2011$ & 155 & C0602CWS & 0 & A & & \\
\hline $3 / 1 / 2011$ & 156 & C0603CWS & 0 & A & & \\
\hline $3 / 8 / 2011$ & 157 & C0604CWS & 0 & A & & \\
\hline $3 / 10 / 2011$ & 158 & C0605CWS & 0 & A & & \\
\hline $3 / 8 / 2011$ & 159 & C0606CWS & 0 & A & & \\
\hline $3 / 8 / 2011$ & 160 & C0607CWS & 3 & A & & \\
\hline $3 / 1 / 2011$ & 161 & C0608CWS & 2 & A & & \\
\hline $3 / 4 / 2011$ & 162 & C0609CWS & 0 & A & & \\
\hline $3 / 2 / 2011$ & 163 & C0611CWS & 1 & B & $0-1$ & \\
\hline $2 / 24 / 2011$ & 164 & C0612CWS & 0 & A & & \\
\hline $3 / 3 / 2011$ & 165 & C0613CWS & 0 & A & & \\
\hline $3 / 17 / 2011$ & 166 & C0616CWS & 0 & A & & \\
\hline $3 / 8 / 2011$ & 167 & C0617CWS & 0 & B & $0-1$ & \\
\hline $3 / 9 / 2011$ & 168 & C0618CWS & 0 & A & & \\
\hline $3 / 8 / 2011$ & 169 & C0619CWS & 0 & A & & \\
\hline $3 / 25 / 2011$ & 170 & C0620CWS & 0 & A & & Damaged by heat \\
\hline $3 / 15 / 2011$ & 171 & C0623CWS & 1 & A & & \\
\hline $3 / 2 / 2011$ & 172 & C0624CWS & 0 & A & & \\
\hline $3 / 17 / 2011$ & 173 & C0625CWS & 0 & A & & \\
\hline $4 / 3 / 2011$ & 174 & C0643CWS & 0 & A & & \\
\hline $1 / 1 / 2011$ & 175 & C0655CWS & 0 & A & & \\
\hline
\end{tabular}


Appendix F. Continued

\begin{tabular}{ccccccc}
\hline Date & Serial & Tooth ID & Age & Confidence & Age range & Aging notes \\
\hline $10 / 30 / 2010$ & 176 & C0676HFT & 0 & A & & IN \\
$10 / 27 / 2010$ & 177 & C0681HFT & 0 & A & & \\
$3 / 30 / 2011$ & 178 & C0684CWS & 1 & A & & \\
$3 / 28 / 2011$ & 179 & C0685CWS & 0 & A & & Damaged by heat \\
$12 / 9 / 2010$ & 180 & C0687CWS & 0 & B & $0-1$ & \\
$3 / 31 / 2011$ & 181 & C0705CWS & 0 & A & & \\
$3 / 2 / 2011$ & 182 & C0706CWS & 0 & A & & \\
$3 / 15 / 2011$ & 183 & C0762CWS & 0 & A & & \\
\hline
\end{tabular}


Appendix G. Reproduction information for female coyotes with fetuses present in West Virginia, January-March 2010.

\begin{tabular}{|c|c|c|c|c|c|c|}
\hline $\begin{array}{c}\text { Coyote } \\
\text { ID }\end{array}$ & $\begin{array}{l}\text { Age of } \\
\text { female }\end{array}$ & $\begin{array}{c}\text { Number } \\
\text { of } \\
\text { fetuses }\end{array}$ & $\begin{array}{c}\text { Average } \\
\text { fetus crown- } \\
\text { rump length } \\
(\mathrm{mm})\end{array}$ & $\begin{array}{c}\text { Approximate } \\
\text { age of fetuses } \\
\text { (days) }\end{array}$ & $\begin{array}{c}\text { Estimated } \\
\text { conception } \\
\text { dates }\end{array}$ & $\begin{array}{l}\text { Estimated } \\
\text { birth date }\end{array}$ \\
\hline 53 & 1 & 4 & 40.75 & 35 & $1-6-2010$ & $3-10-2010$ \\
\hline 69 & 1 & 5 & 14.2 & 30 & $1-25-2010$ & $3-29-2010$ \\
\hline 114 & 1 & 6 & 104.02 & 47 & $1-27-2010$ & $3-31-2010$ \\
\hline 130 & 1 & 6 & 31.05 & 33 & $2-26-2010$ & $4-30-2010$ \\
\hline 131 & 1 & 7 & 68.11 & 41 & $2-11-2010$ & $4-15-2010$ \\
\hline 133 & 1 & 4 & 52.88 & 38 & $2-8-2010$ & $4-12-2010$ \\
\hline 138 & 4 & 9 & 87.12 & 44 & $1-27-2010$ & $3-31-2010$ \\
\hline 144 & 1 & 7 & 160.4 & 58 & $2-3-2010$ & $4-7-2010$ \\
\hline \multirow[t]{2}{*}{151} & 1 & 5 & 59.38 & 39 & $2-11-2010$ & $4-15-2010$ \\
\hline & & & & Average Dates & $2-2-2010$ & $4-6-2010$ \\
\hline
\end{tabular}


Appendix H. Number of coyote scat collected by county, year, and month in West Virginia, November 2009-June 2011.

\begin{tabular}{|c|c|c|c|}
\hline County & Year & Month & Number of scat \\
\hline \multirow[t]{21}{*}{ Lewis } & 2010 & January & 0 \\
\hline & & February & 2 \\
\hline & & March & 15 \\
\hline & & April & 10 \\
\hline & & May & 6 \\
\hline & & June & 4 \\
\hline & & July & 2 \\
\hline & & August & 2 \\
\hline & & September & 0 \\
\hline & & October & 2 \\
\hline & & November & 0 \\
\hline & & December & 0 \\
\hline & 2011 & January & 6 \\
\hline & & February & 1 \\
\hline & & March & 4 \\
\hline & & April & 5 \\
\hline & & May & 0 \\
\hline & & June & 0 \\
\hline & & July & 0 \\
\hline & & August & 0 \\
\hline & & September & 0 \\
\hline
\end{tabular}


Appendix H. Continued

\begin{tabular}{|c|c|c|c|}
\hline County & Year & Month & Number of scat \\
\hline \multirow[t]{3}{*}{ Lewis } & 2011 & October & 0 \\
\hline & & November & 0 \\
\hline & & December & 0 \\
\hline \multirow[t]{19}{*}{ Pocahontas } & 2010 & January & 2 \\
\hline & & February & 0 \\
\hline & & March & 1 \\
\hline & & April & 27 \\
\hline & & May & 28 \\
\hline & & June & 29 \\
\hline & & July & 20 \\
\hline & & August & 54 \\
\hline & & September & 54 \\
\hline & & October & 0 \\
\hline & & November & 0 \\
\hline & & December & 0 \\
\hline & 2011 & January & 0 \\
\hline & & February & 10 \\
\hline & & March & 34 \\
\hline & & April & 36 \\
\hline & & May & 25 \\
\hline & & June & 17 \\
\hline & & July & 0 \\
\hline
\end{tabular}


Appendix H. Continued

\begin{tabular}{|c|c|c|c|}
\hline County & Year & Month & Number of scat \\
\hline \multirow[t]{5}{*}{ Pocahontas } & 2011 & August & 0 \\
\hline & & September & 0 \\
\hline & & October & 0 \\
\hline & & November & 0 \\
\hline & & December & 0 \\
\hline \multirow[t]{17}{*}{ Raleigh } & 2010 & January & 1 \\
\hline & & February & 0 \\
\hline & & March & 4 \\
\hline & & April & 16 \\
\hline & & May & 9 \\
\hline & & June & 13 \\
\hline & & July & 1 \\
\hline & & August & 18 \\
\hline & & September & 35 \\
\hline & & October & 35 \\
\hline & & November & 56 \\
\hline & & December & 0 \\
\hline & 2011 & January & 11 \\
\hline & & February & 31 \\
\hline & & March & 14 \\
\hline & & April & 12 \\
\hline & & May & 29 \\
\hline
\end{tabular}


Appendix H. Continued

\begin{tabular}{lrrr}
\hline County & Year & \multicolumn{1}{c}{ Month } & Number of s cat \\
\hline Raleigh & 2011 & June & 0 \\
& July & 0 \\
& August & 0 \\
& September & 0 \\
& October & 0 \\
& November & 0 \\
& December & 0 \\
& & 0
\end{tabular}


Appendix I. Maps of scat routes in Lewis, Pocahontas, and Raleigh Counties, West Virginia, where coyote scat collection occurred January 2010-May 2011.

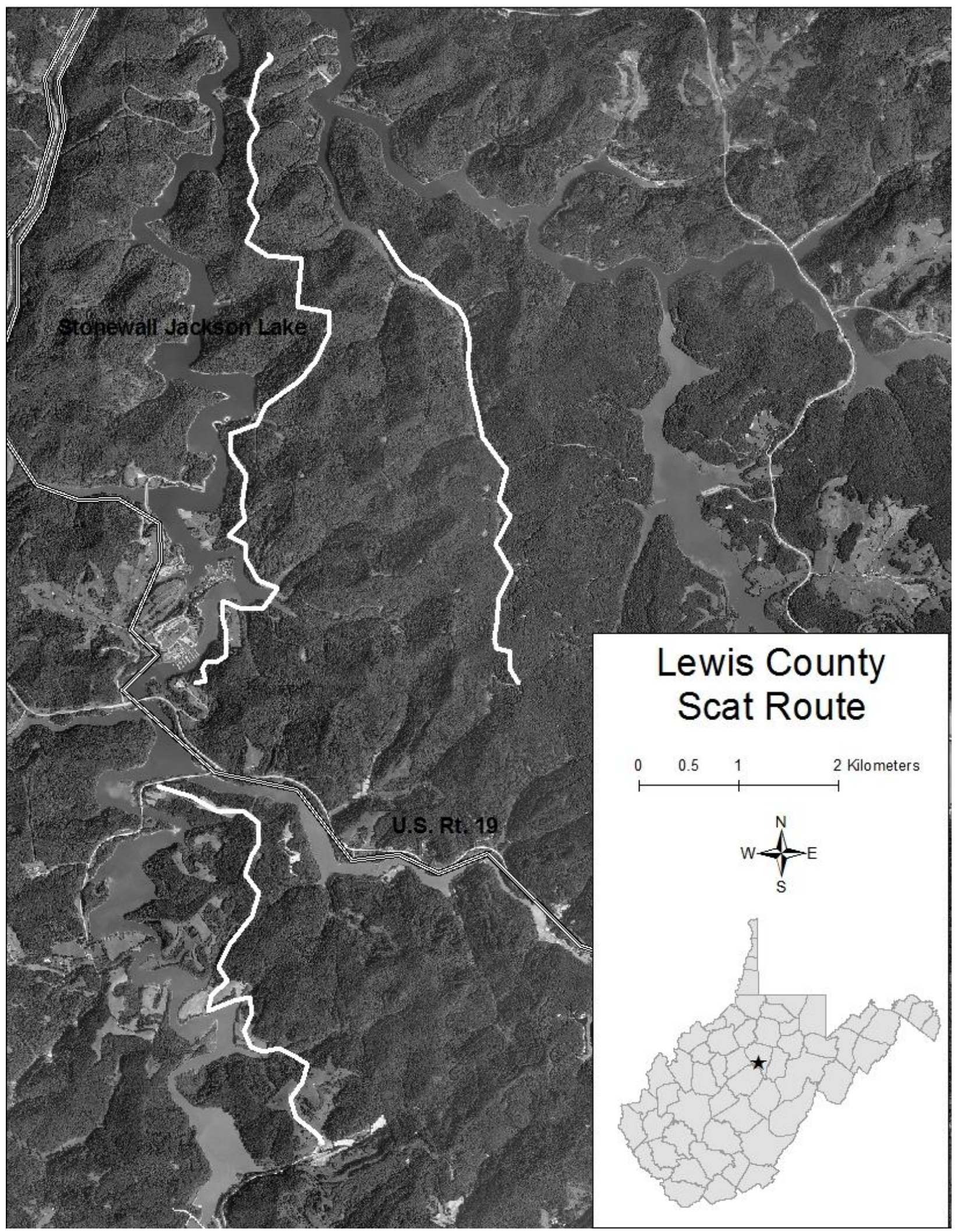


Appendix I. Continued

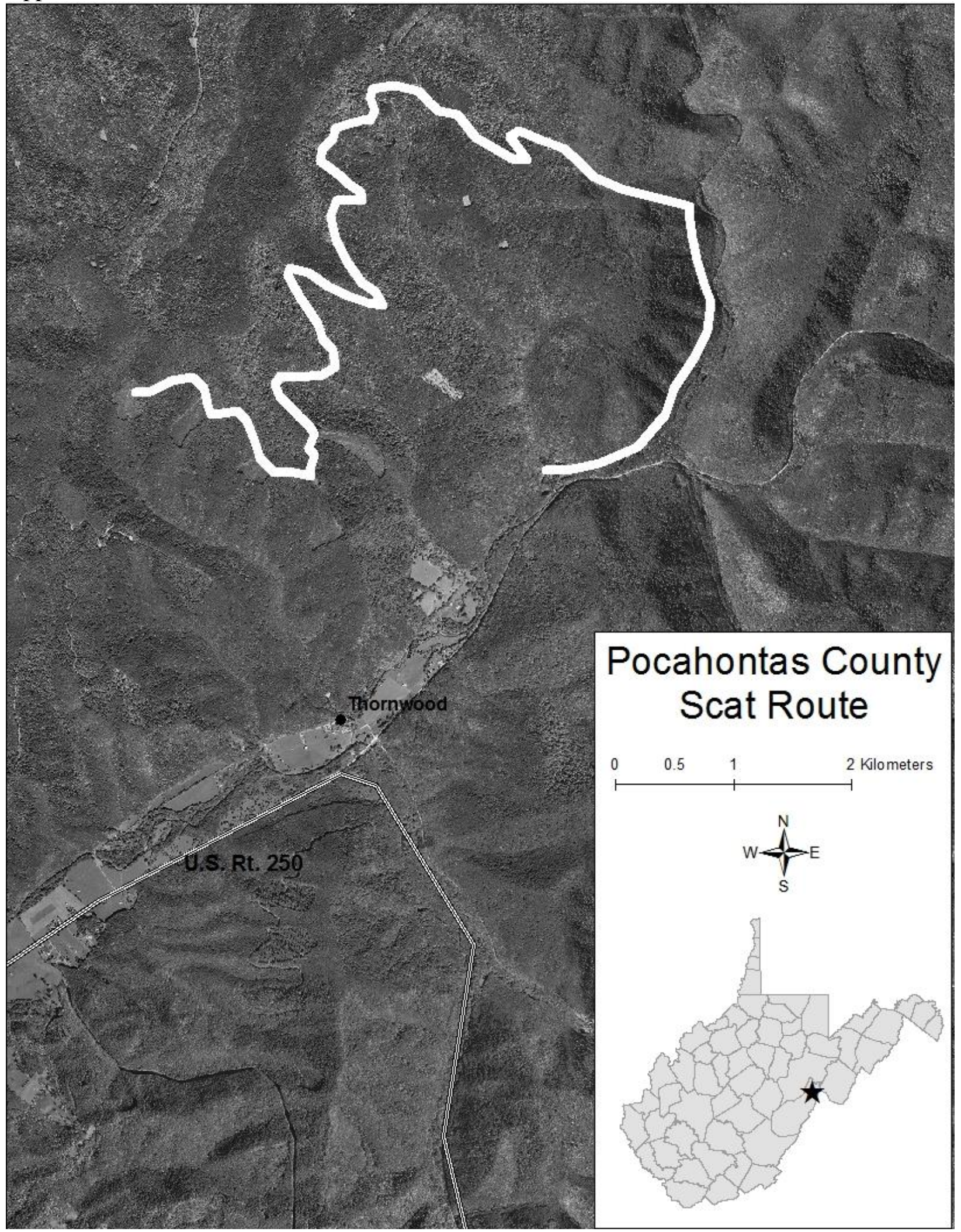


Appendix I. Continued

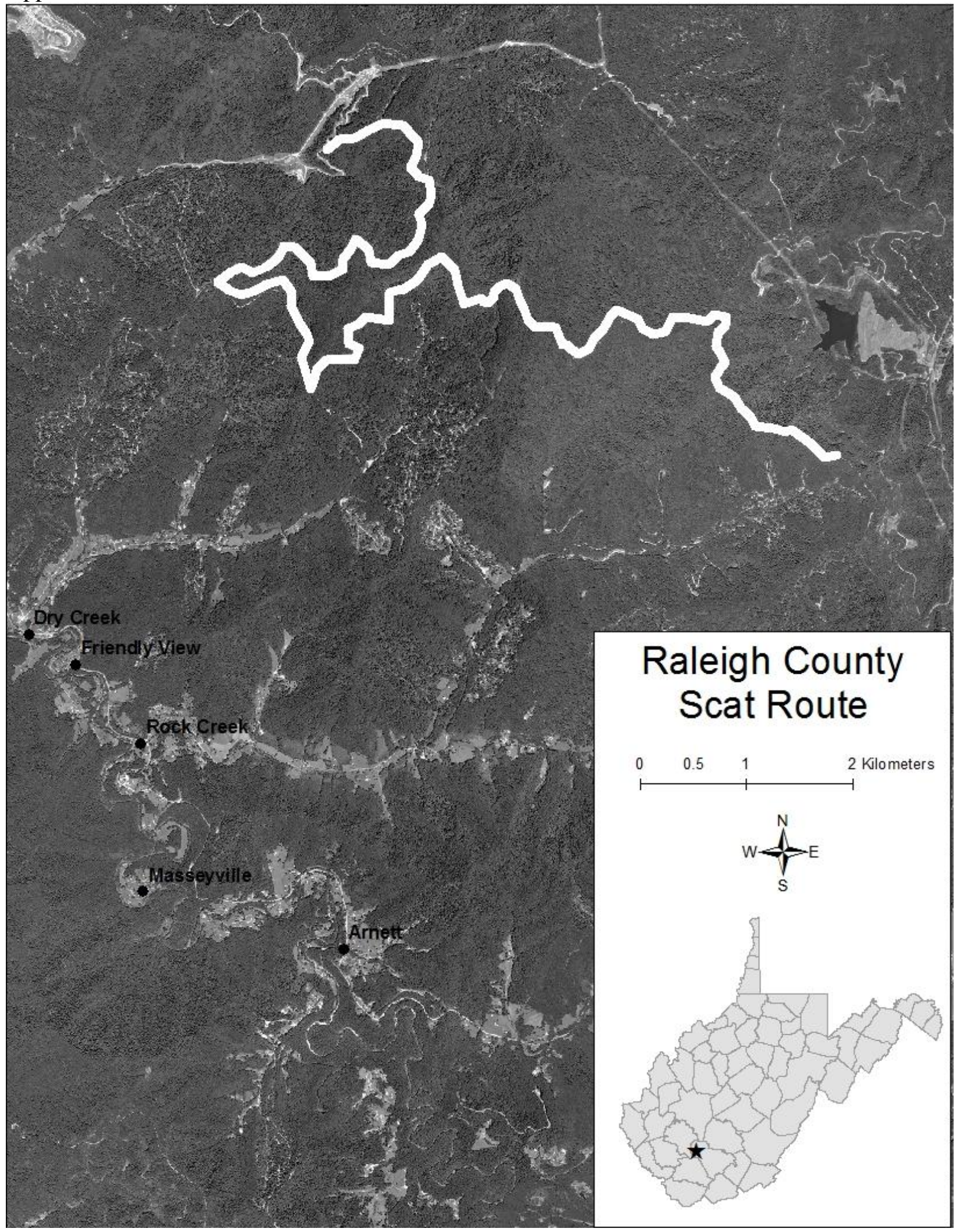


Appendix J. Maps of deer distance survey routes in Lewis, Pocahontas, and Raleigh Counties, West Virginia where distance surveys were conducted as part of the Coyote Diet Study in September 2010.

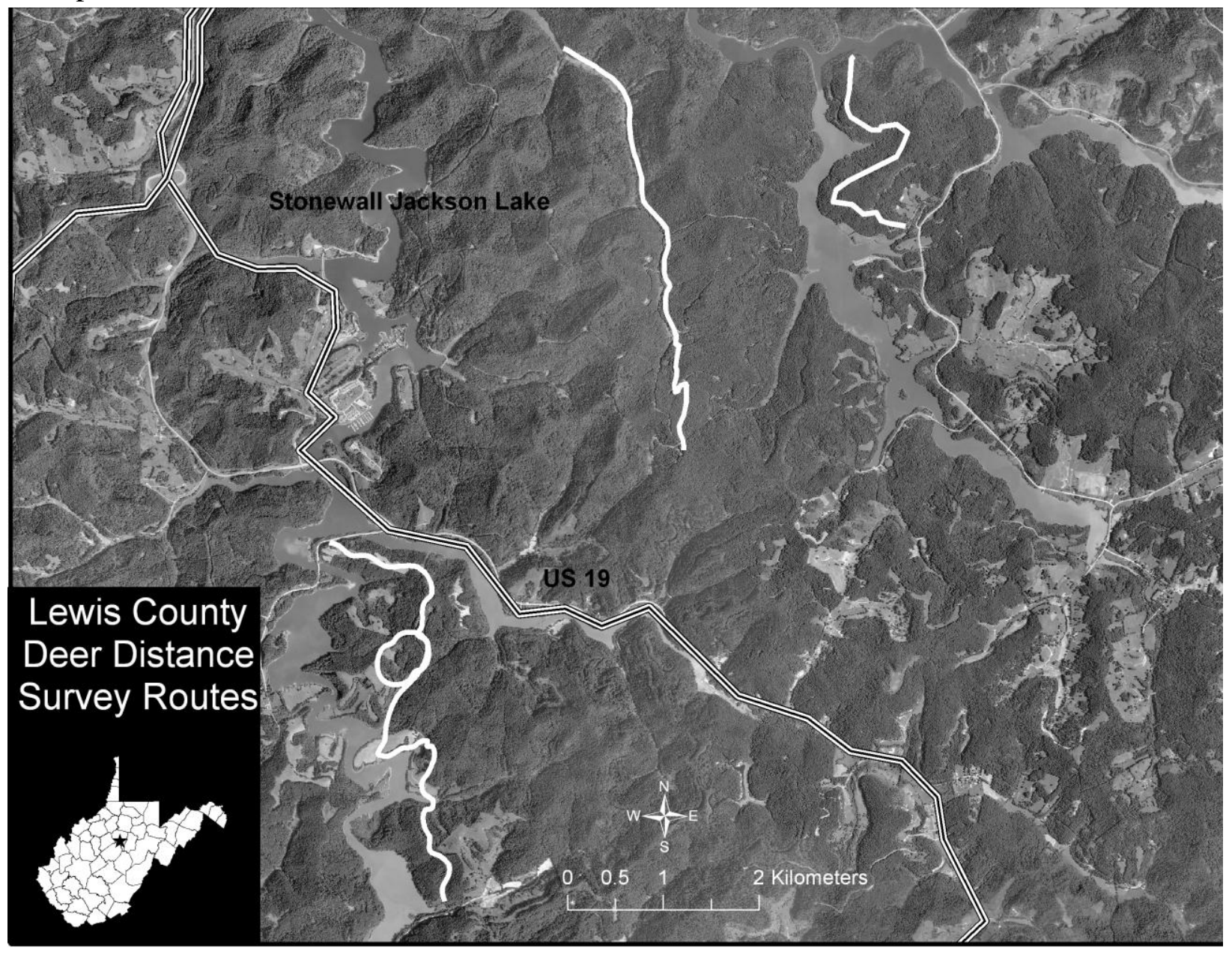


Appendix J. Continued

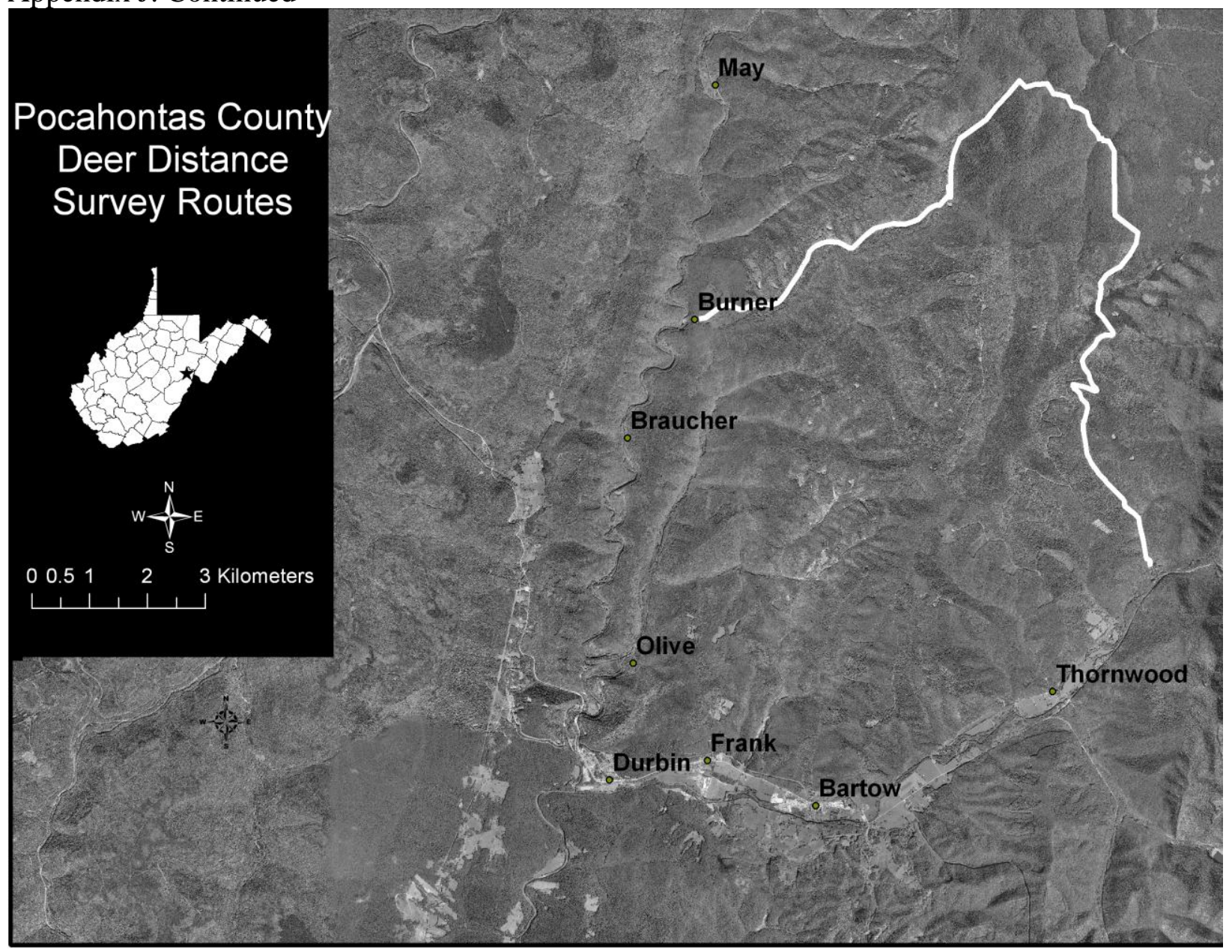




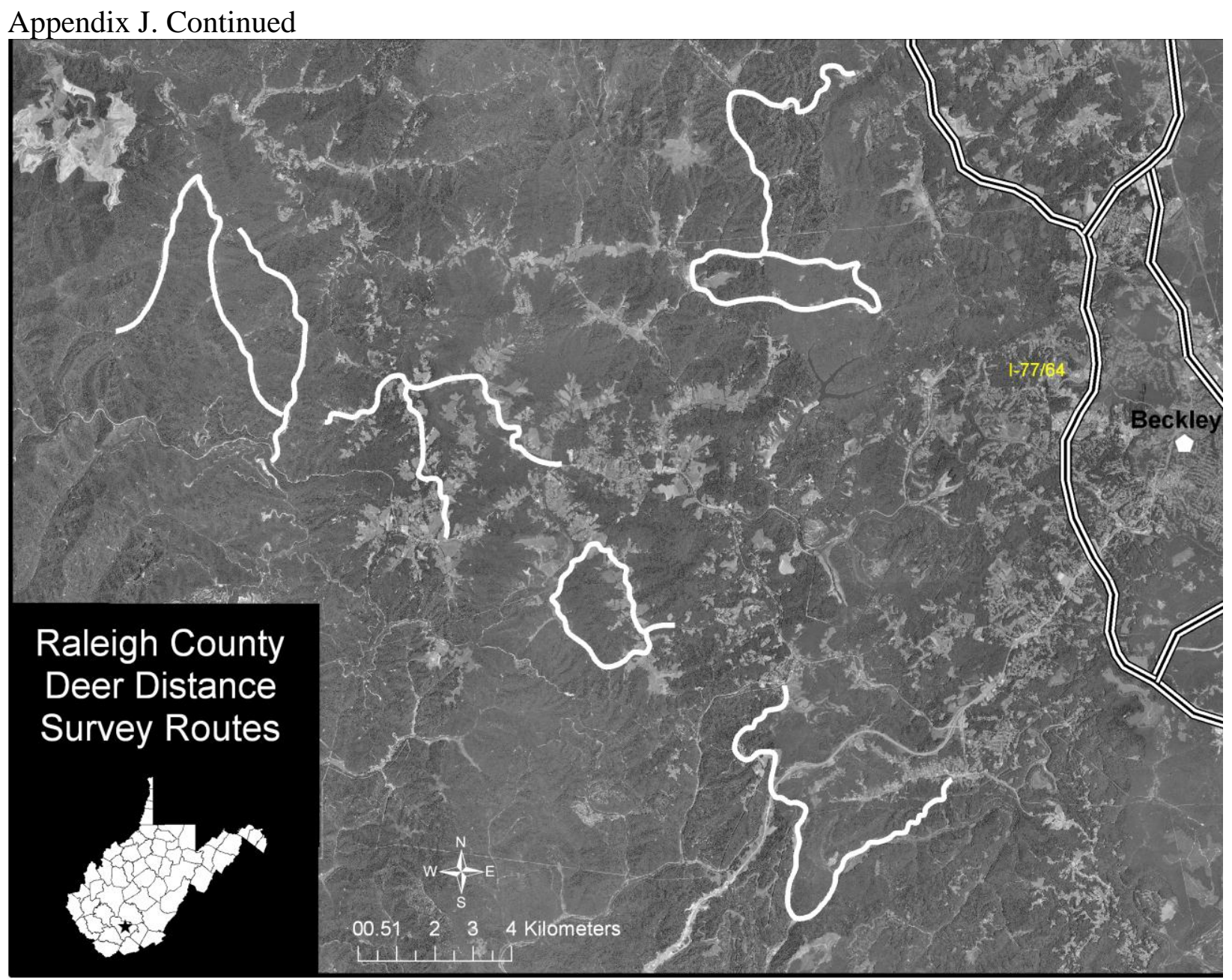

